\title{
LA--11176 -OBES
}

DE88 007156

\section{Core $\log$}

Valles Caldera \#2A,

New Mexico

Virginia L. Starquist * 



\section{DISCLAIMER}

This report was prepared as an account of work sponsored by an agency of the United States Government. Neither the United States Government nor any agency Thereof, nor any of their employees, makes any warranty, express or implied, or assumes any legal liability or responsibility for the accuracy, completeness, or usefulness of any information, apparatus, product, or process disclosed, or represents that its use would not infringe privately owned rights. Reference herein to any specific commercial product, process, or service by trade name, trademark, manufacturer, or otherwise does not necessarily constitute or imply its endorsement, recommendation, or favoring by the United States Government or any agency thereof. The views and opinions of authors expressed herein do not necessarily state or reflect those of the United States Government or any agency thereof. 


\section{DISCLAIMER}

Portions of this document may be illegible in electronic image products. Images are produced from the best available original document. 
CORE LOG

VALLES CALDERA \#2A, NEW MEXICO

\title{
by
}

Virginia L. Starquist

\begin{abstract}
Scientific core hole VC-2A was drilled into the western ring-fracture zone at Sulphur Springs in the Valles caldera, New Mexico. VC-2A, the second scientific core hole in the caldera, was cored through a faulted and brecciated sequence of intracauldron tuffs and volcaniclastic rocks to a depth of $528 \mathrm{~m}$. As of November 1, 1986, the unequilibrated bottom-hole temperature was $212^{\circ} \mathrm{C}$. The rocks penetrated are intensely altered and host sub-ore grade stockwork molybdenite mineralization between 25 and $125 \mathrm{~m}$. This report contains a detailed core log to aid researchers in their studies of the Valles caldera magma hydrothermal system.
\end{abstract}

\section{INTRODUCTION}

Valles caldera \#2A (VC-2A) is the second scientific core hole drilled into the Valles caldera as a part of the Continental Scientific Drilling Program (Fig. 1). The primary objective of $V C-2 A$ was to penetrate the vapor zone beneath the acid-sulfate hot spring system of Sulphur Springs on the western edge of the resurgent dome inside the caldera (Goff and Nielson 1986). Secondary objectives were to core through the interface between the vapor zone and the hot water-dominated zone, to obtain structural and stratigraphic data 


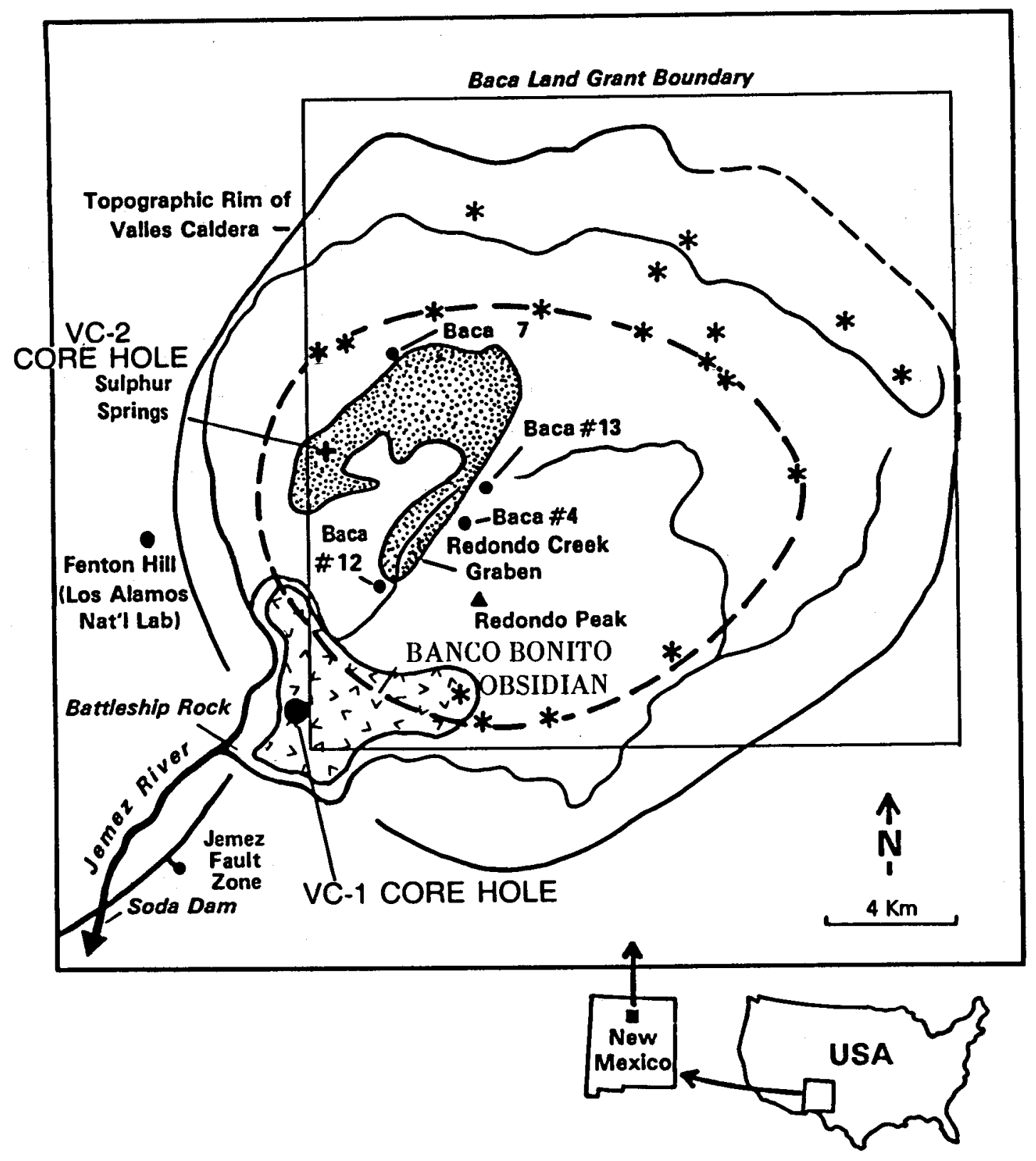

Fig. 1.

Schematic map of Valles caldera region showing location of VC-2A. 
on the caldera fill rocks along the ring-fracture resurgent-dome boundary, and to determine possible mechanisms of ore deposition in an active caldera hydrothermal system.

Over 98\% of HQ core (62-mm diameter) throughout the entire length of the bore was successfully recovered. The core hole was spudded on September 5, 1986, and completed in 24 days. Total depth is $527.7 \mathrm{~m}(1731 \mathrm{ft})$ and the unequilibrated bottom-hole temperature (BHT) was $212^{\circ} \mathrm{C}\left(410^{\circ} \mathrm{F}\right)$ as of November 1, 1986. The core from 366 core runs averaging $5 \mathrm{ft}$ in length is stored in 224 boxes.

A core $\log$ in the Appendix provides detailed information on rock types, coherency, mineralization, alteration, and rock structures observed in the core. It is intended to be used by researchers who wish to work on research projects associated with the Valles caldera scientific drilling program or other research problems. All core was cleaned, labeled, and boxed according to the sampling procedures of S. Goff (1986). Those who wish to obtain core should contact Fraser Goff or Jamie Gardner, ESS-1, D462, Los Alamos National Laboratory, Los Alamos, NM 87545 or Dennis Nielson or Jeff Hulen, University of Utah Research Institute, 391 Chipeta Way, Suite C, Salt Lake City, UT 84108. After the summer of 1987, all core will be stored at the US Department of Energy Core Repository in Grand Junction, Colorado. The curator of this repository is Richard Dayvault.

\section{DISCUSSION}

For description of the core in VC-2A, a two-facing-page log was utilized (see Appendix). The first page contains a heading with general information, drilling dates, depth, and number of boxes and runs. Lithology was graphically logged at a scale of $3 / 4 \mathrm{in}$. $=5 \mathrm{ft}$, there being $50 \mathrm{ft}(15.25 \mathrm{~m})$ per page. A coherency profile shows the competency of the rock, and separate columns show specific mineralization. The second page of the set has similar headings and a number of columns for noting core recovery (in feet per run), the run number, and descriptions of structures including sketches of fractures and broken zones, the angle of dip of fractures and infillings, fracture frequency (number of fractures per run), and relative porosity. Sections of core were waxed at selected intervals and are indicated with a special symbol ( and a sample number with the corresponding depth, i.e., W\#19-1, 61-61.9'. 
A summary section of $\mathrm{VC}-2 \mathrm{~A}$ is shown in Fig. 2. At the top of the core hole, the first rocks encountered were landslide debris and volcaniclastic sediments. The greater portion, however, consists of various ash-flow tuffs, with lesser intervals of air-fall tuffs and tuff breccias. Also encountered were thin intervals of sandstone and cataclastic rocks.

Most of the rocks are hydrothermally altered. In much of the tuff sequence the lithic fragments and fiamme are altered to pale green clay. From $435 \mathrm{~m}$ (1428 ft) to total depth, the matrix is also composed of green clay giving a distinctive green turquoise color to the rock. These clays have been analyzed by $x$-ray diffraction and consist of sericite-montmorillonite-illite with or without chlorite. In many instances the plagioclase in the rock is altered to soft clay, and the rock consequently appears to be pitted. In the upper part of the hole there are intervals of "splotchy" appearance that are due to a hydrothermal alteration overprint on devitrified welded tuff.

A number of interesting structures were observed in the tuffs. Most conspicuous are a number of breccias; small vein breccias, fault breccias, and coarse-grained tuff breccias. At $487 \mathrm{~m}(1596 \mathrm{ft})$ there is a possible intrusion breccia displaying angular lithic fragments in a matrix of calcite and green clay. This zone has a flaring cylindrical shape, $65-70^{\circ}$ from core vertical, but is only a few centimeters in length. At $477 \mathrm{~m}(1565 \mathrm{ft})$ there appear to be welded pumice trains in very fine grained tuff. Mylonites are observed at several locations in the vicinity of $479 \mathrm{~m}(1570 \mathrm{ft})$. A spectacular section of bedded, fall-out tuffs occurs from 373 to $380 \mathrm{~m}$ (1225 to $1248 \mathrm{ft}$ ).

Alteration minerals were observed with the binocular microscope. Pyrite is always present, from 1 to $10 \%$, and usually noticed as striated cubes, 1-2 mm in size. The next most common mineral is calcite, seldom disseminated, but rather in slender veins, these often with chloritic selvages. Molybdenite occurs as black coatings, not with the usual coarsely crystalline blue aspect, and is associated with $\mathrm{Mn}, \mathrm{Zn}, \mathrm{Pb}$, and $\mathrm{Cu}$. It is fairly common along fractures in the region of the hole between 25 and $125 \mathrm{~m}$ (Hulen et al. 1987). Amorphous hematite appears rarely as small patches of red stain. There is one notable occurrence of green fluorite in 2-cm octahedrons in a vein breccia at $165 \mathrm{~m}$ $(540 \mathrm{ft})$. Very small crystals of rutile occur at $516 \mathrm{~m}(1694 \mathrm{ft})$. The rutile is associated with a druse of calcite crystals, and a zinc sulphide, probably sphalerite. Rhodochrosite was logged at $167 \mathrm{~m}(550 \mathrm{ft})$. 


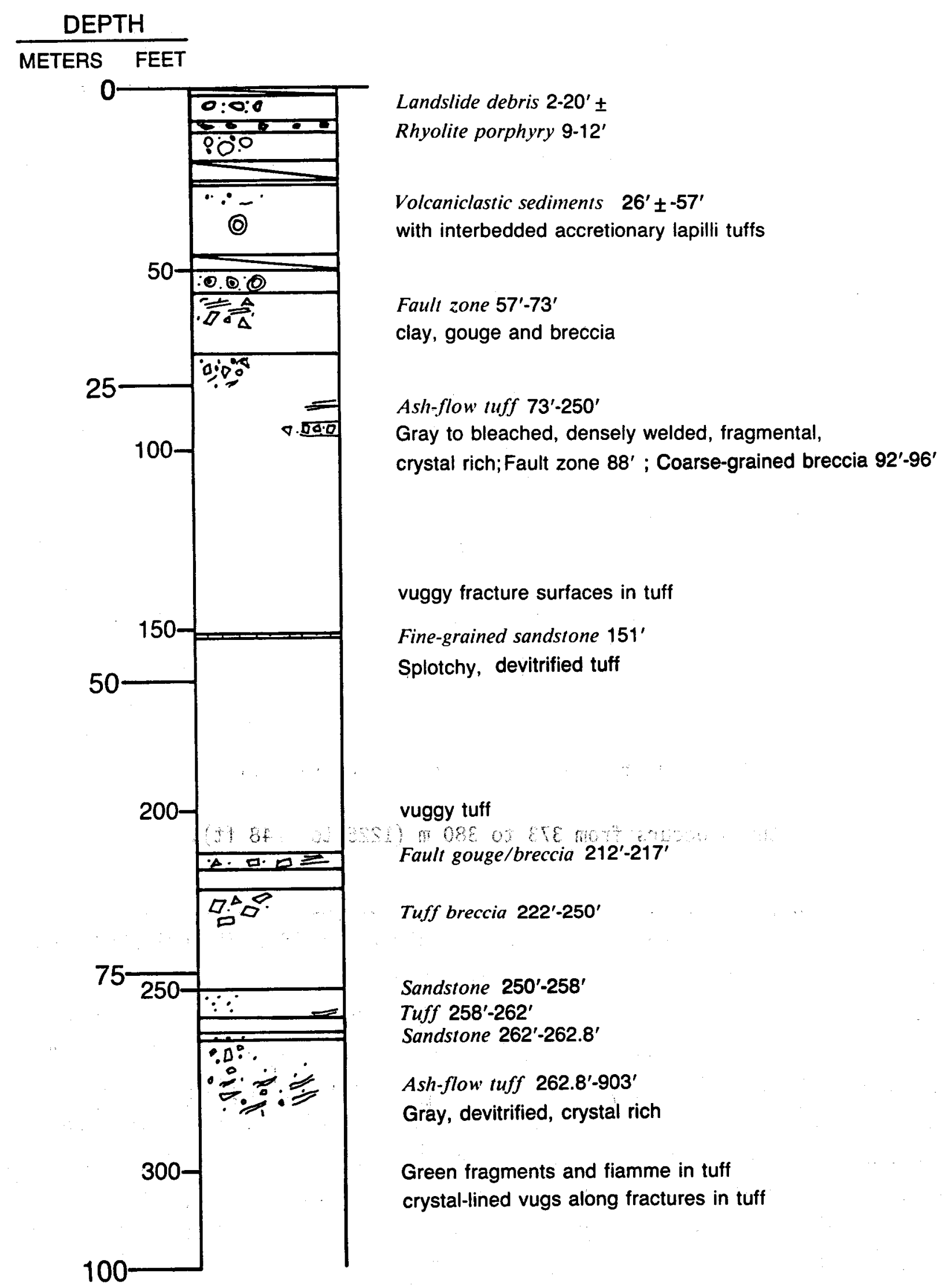

Fig. 2.

Summary section of VC-2A. 


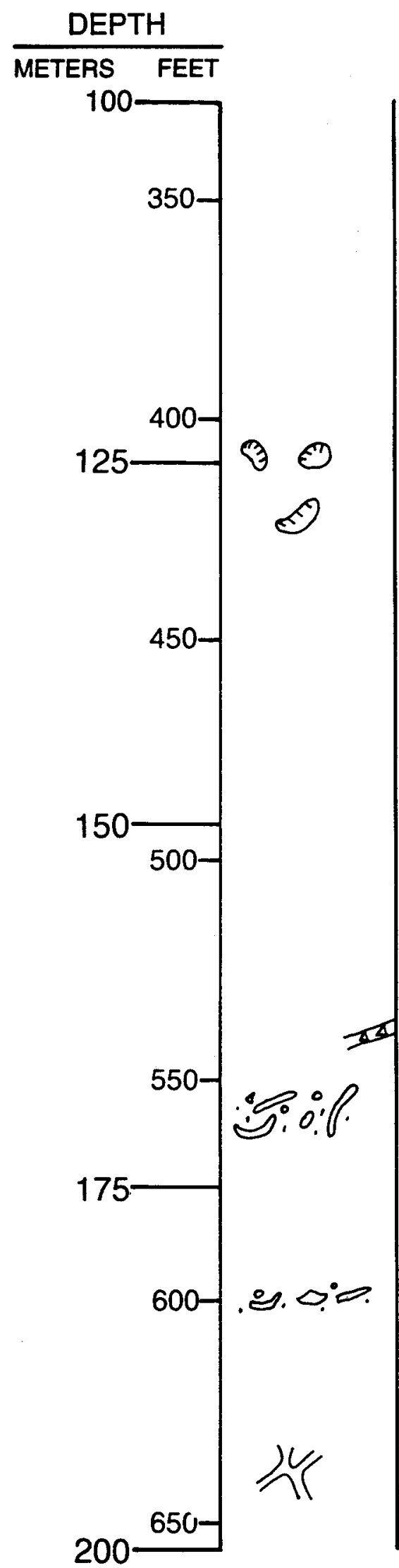

patchy devitrification in tuff

vugs conspicuous at $401^{\prime}-491^{\prime}$ are

filled with clay and/or pyrite

and quartz crystals

bleached and devitrified tuff

smaller vugs $530^{\prime}-552^{\prime} \pm$

Vein breccia with fluorite crystals, 540'

Conspicuous green clay in veins and pods, and as vug filling

green fiamme in tuff

calcite veins with chloritic selvages in tuff

Fig. 2. (cont) 


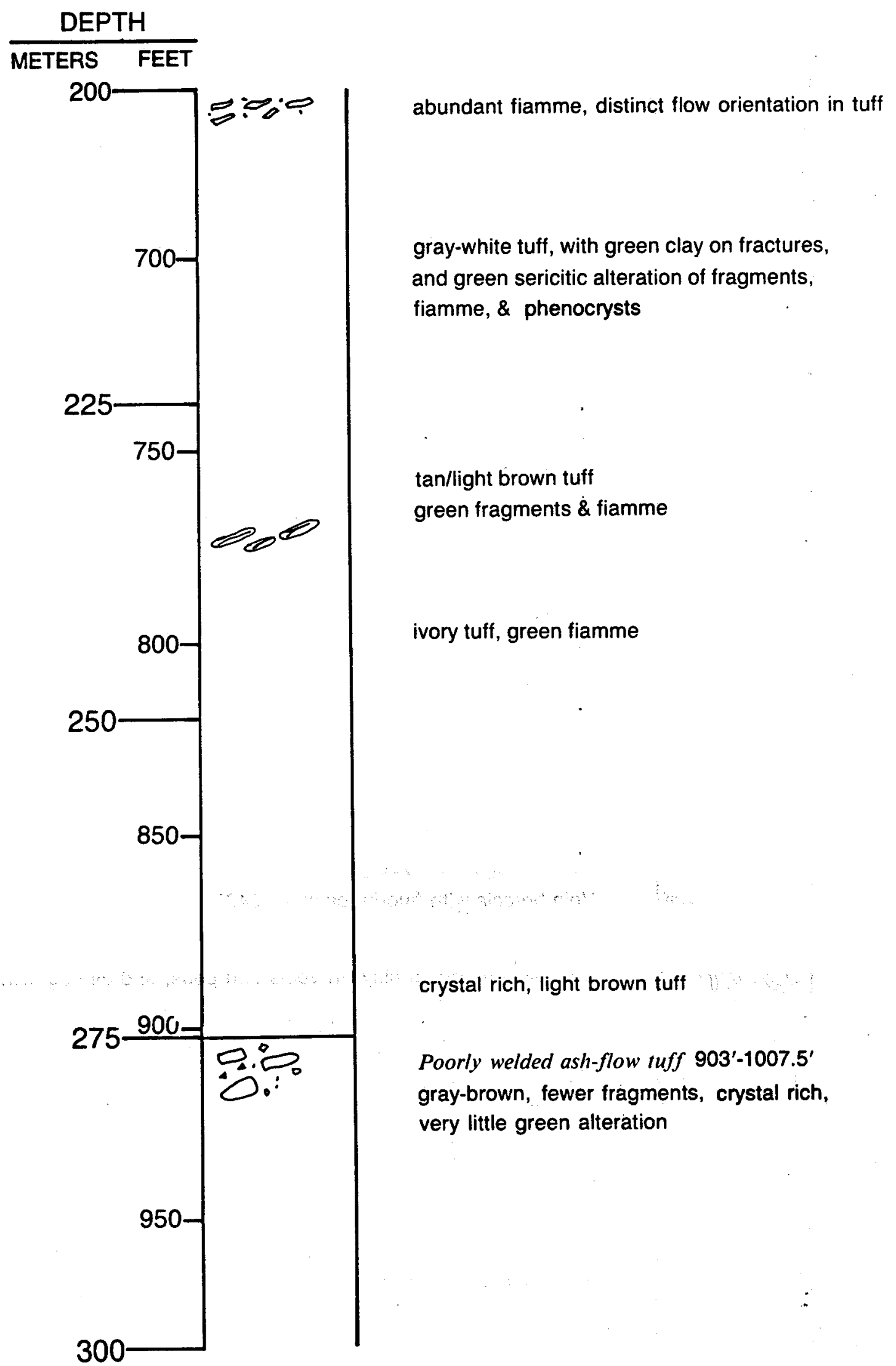

Fig. 2. (cont) 


\section{DEPTH}

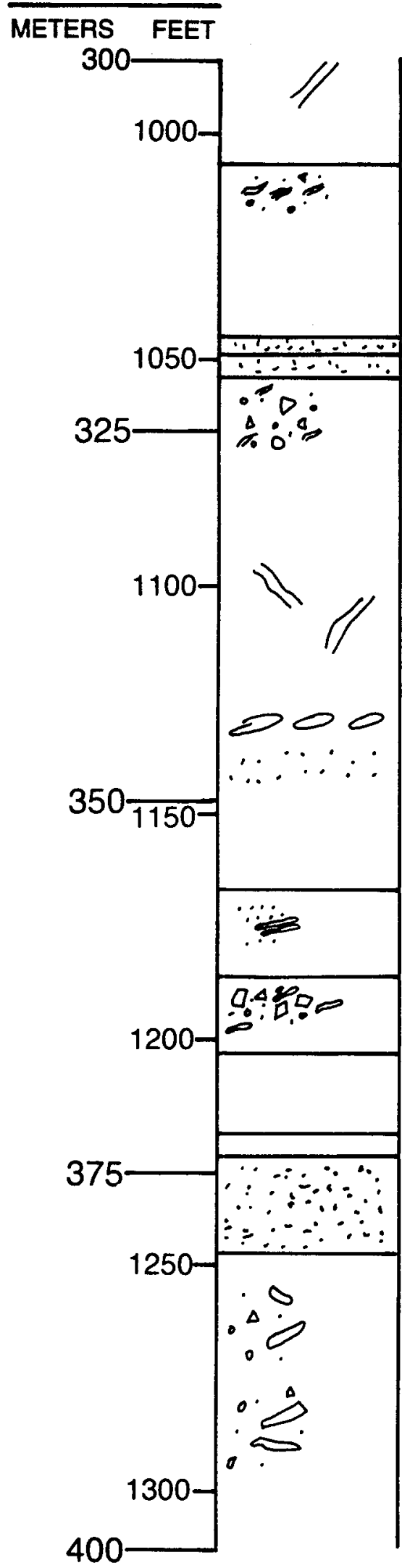

calcite veins with chloritic selvages

Densely welded tuff 1007.5'-1046' \pm dark gray, fragmental, swirly fabric very little green alteration

Air-fall tuff $1049.2^{\prime}-1054^{\prime} \pm$

Fragmental tuff 1054' $\pm-1167.5^{\prime}$

gray, crystal rich; fiamme

conspicuous calcite veins with chloritic selvages $1095^{\prime}-1152^{\prime}$

green fiamme \& fragments in tuff pitted tuff

Sandy tuff/tuffaceous sandstone $1167.5^{\prime} \pm-1186.3^{\prime}$ with bedding

Fragmental tuff $1186.3^{\prime}-1203^{\prime} \pm$ densely welded, It.tan with green fiamme Partially welded tuff $1203^{\prime} \pm-1221^{\prime}$ pitted, bleached, fragmental; inconspicous. fiamme Densely welded tuff (?) 1221'-1225.5'

Fall-out tuffs 1225.5'-1248'

Moderately welded tuffs 1248'-1382.5'

to non welded tuffs

grey, pitted tuff

random fragments in tuff

inconspicuous pumice in tuff

Fig. 2. (cont) 


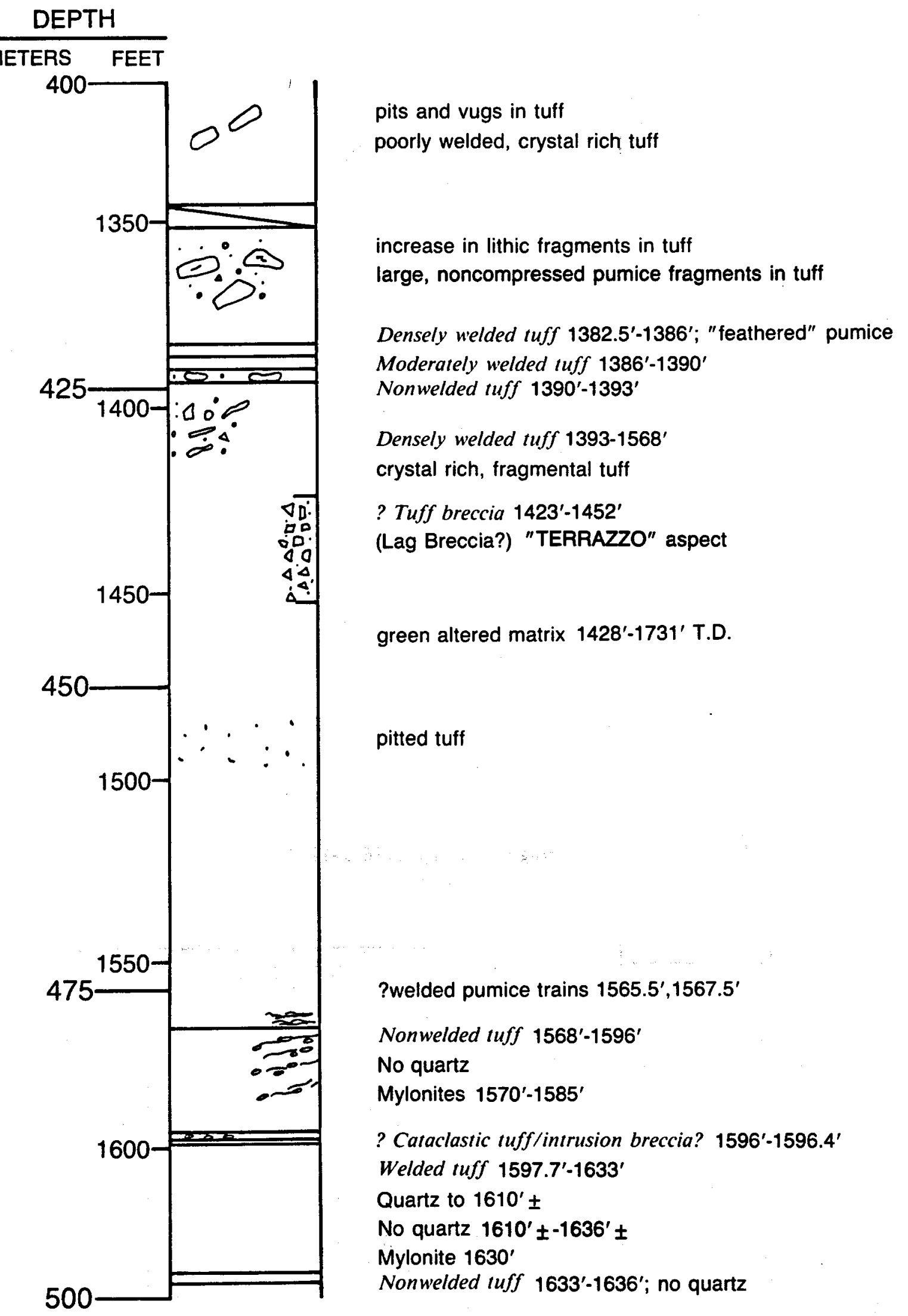

Fig. 2. (cont) 


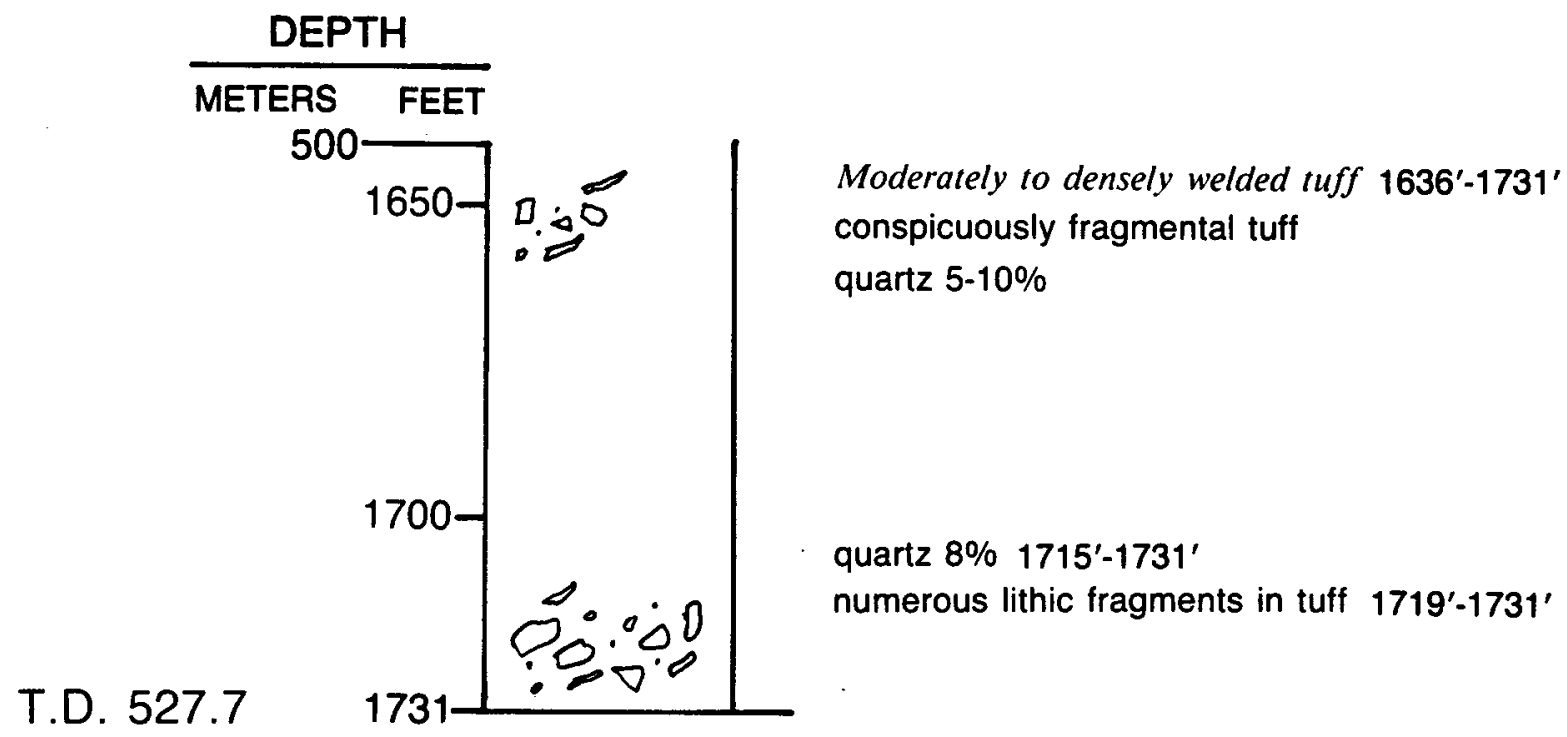

Fig. 2. (cont) 
Mineralization on fractures consists mainly of potassium clays and calcite, sericite clays with or without chlorite, pyrite and pyrite mud, and ore minerals such as the molybdenite. A general observation can be made that low-angle fractures $\left(0-30^{\circ}\right)$ tend to exhibit clean surfaces, whereas the higherangle fractures are the ones with the vein infillings mentioned above.

\section{ACKNOWLEDGMENTS}

The author wishes to thank Greg Bayhurst of INC Division for $x$-ray diffraction analyses and Robert Baran of ESS Division for field and laboratory assistance.

\section{REFERENCES}

Goff, F., and D. L. Nielson, "Caldera Processes and Magma-Hydrothermal Systems: Continental Scientific Drilling Program--Thermal Regimes, Valles Caldera Research, Scientific and Management Plan," Los Alamos National Laboratory report LA-10737-OBES (May 1986).

Goff, S. "Curatorial Policy Guidelines and Procedures for the Continental Scientific Drilling Progam," Los Alamos National Laboratory report LA-10542-OBES (January 1986).

Hulen, J. B., F. Goff, D. L. Nielson, J. N. Gardner, and R. W. Charles, 1987. "Molybdenum Mineralization in an Active Geothermal System, Valles Caldera, New Mexico," Geology (in press). 


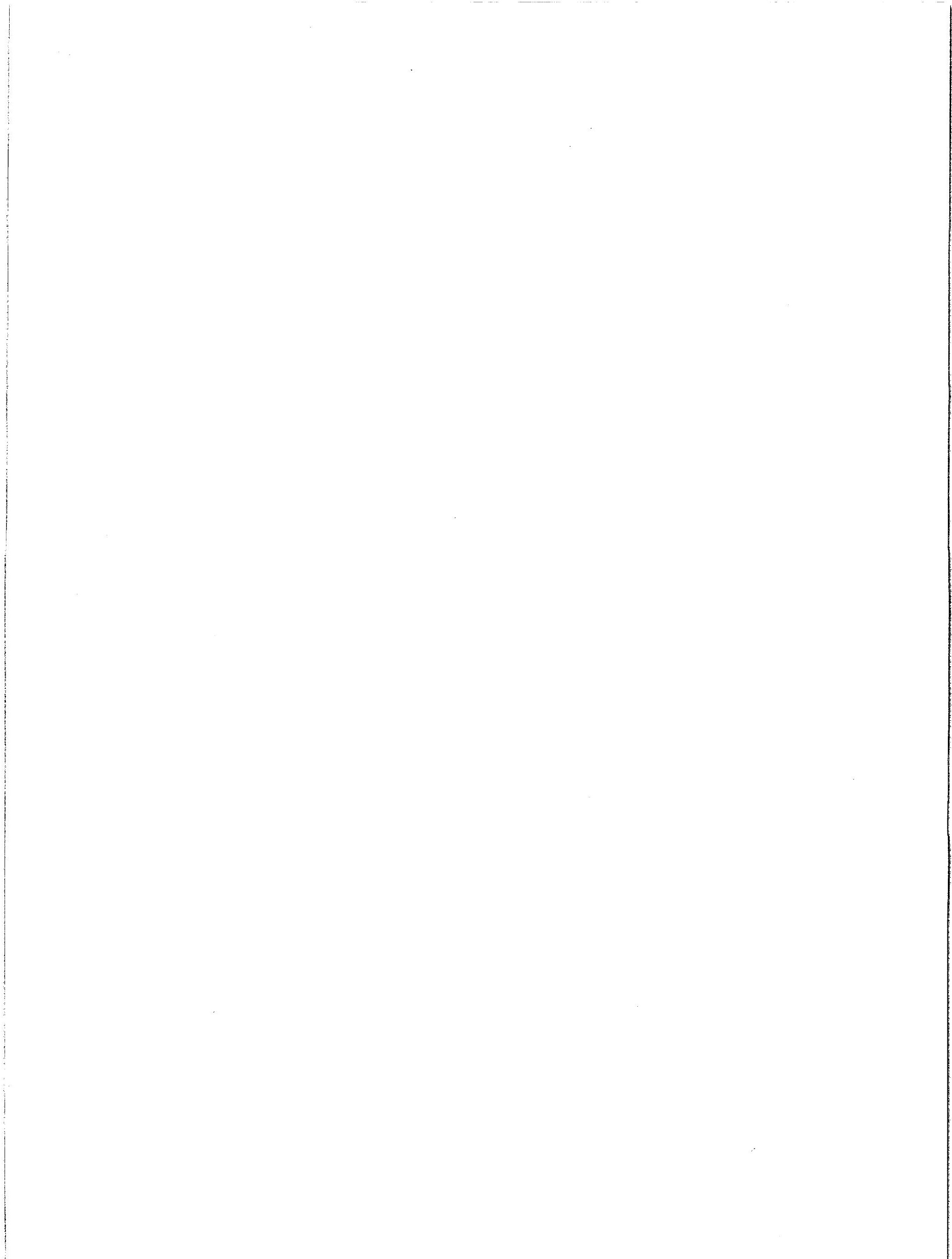




\section{APPENDIX}

VC-2A CORE LOG 


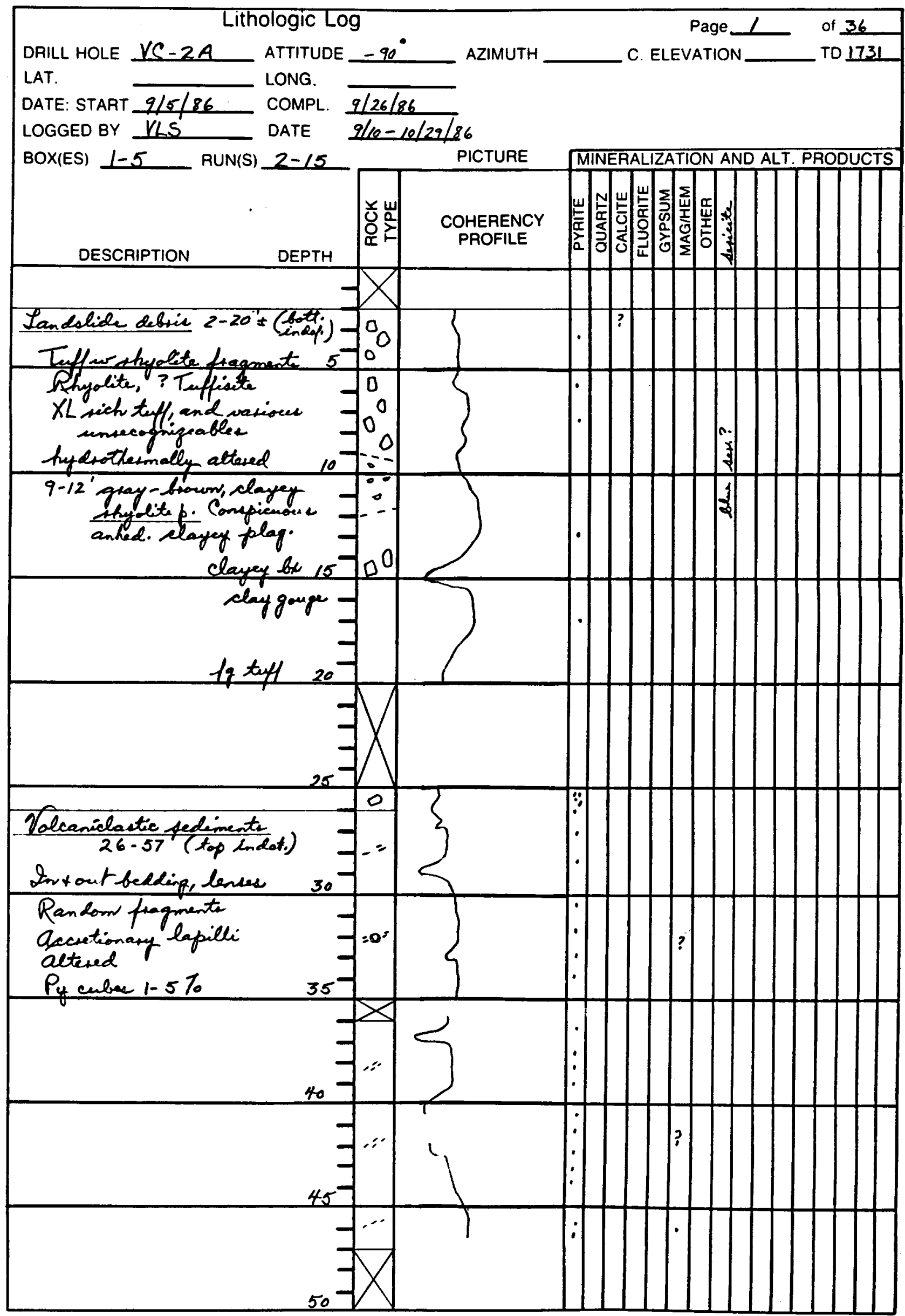




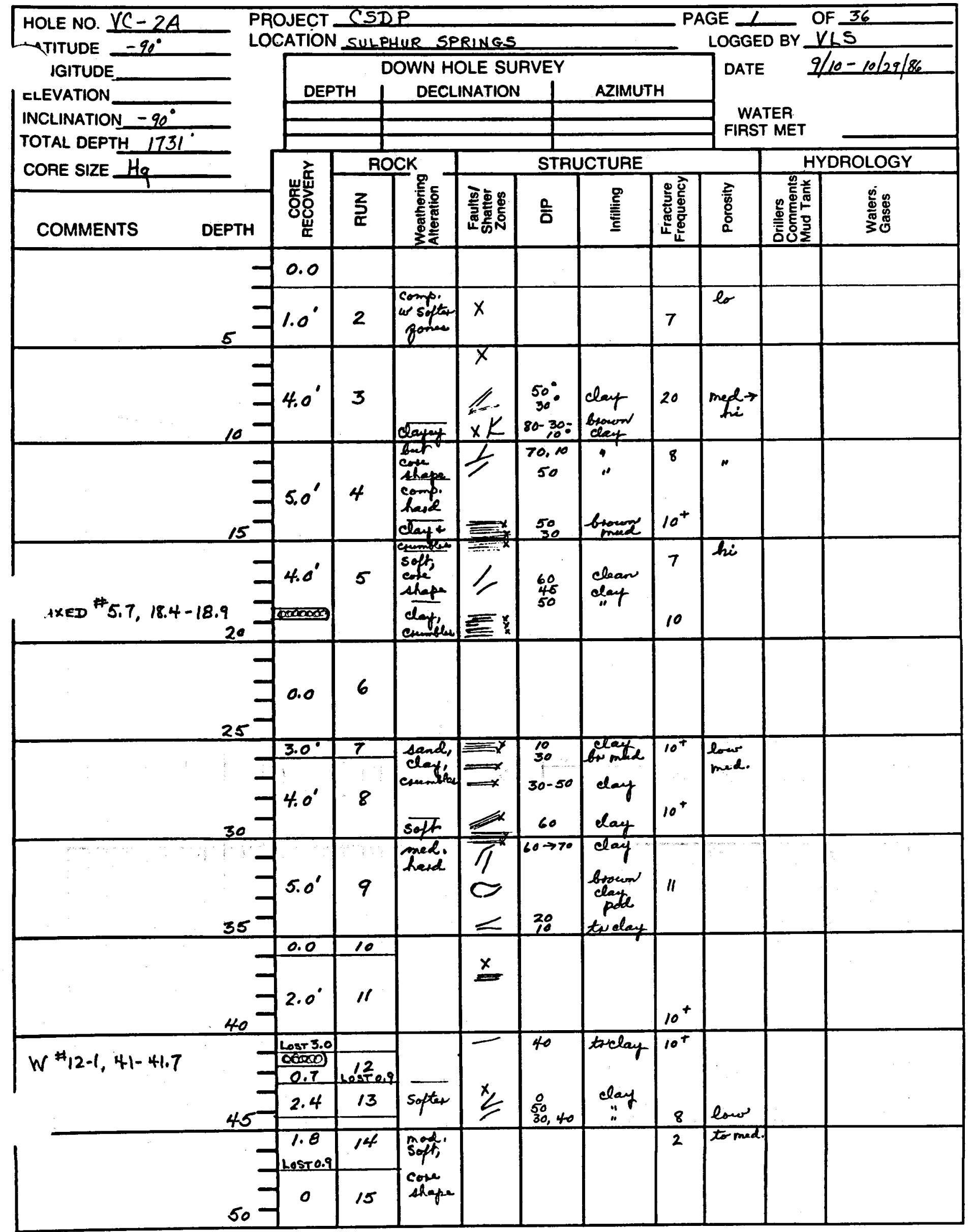




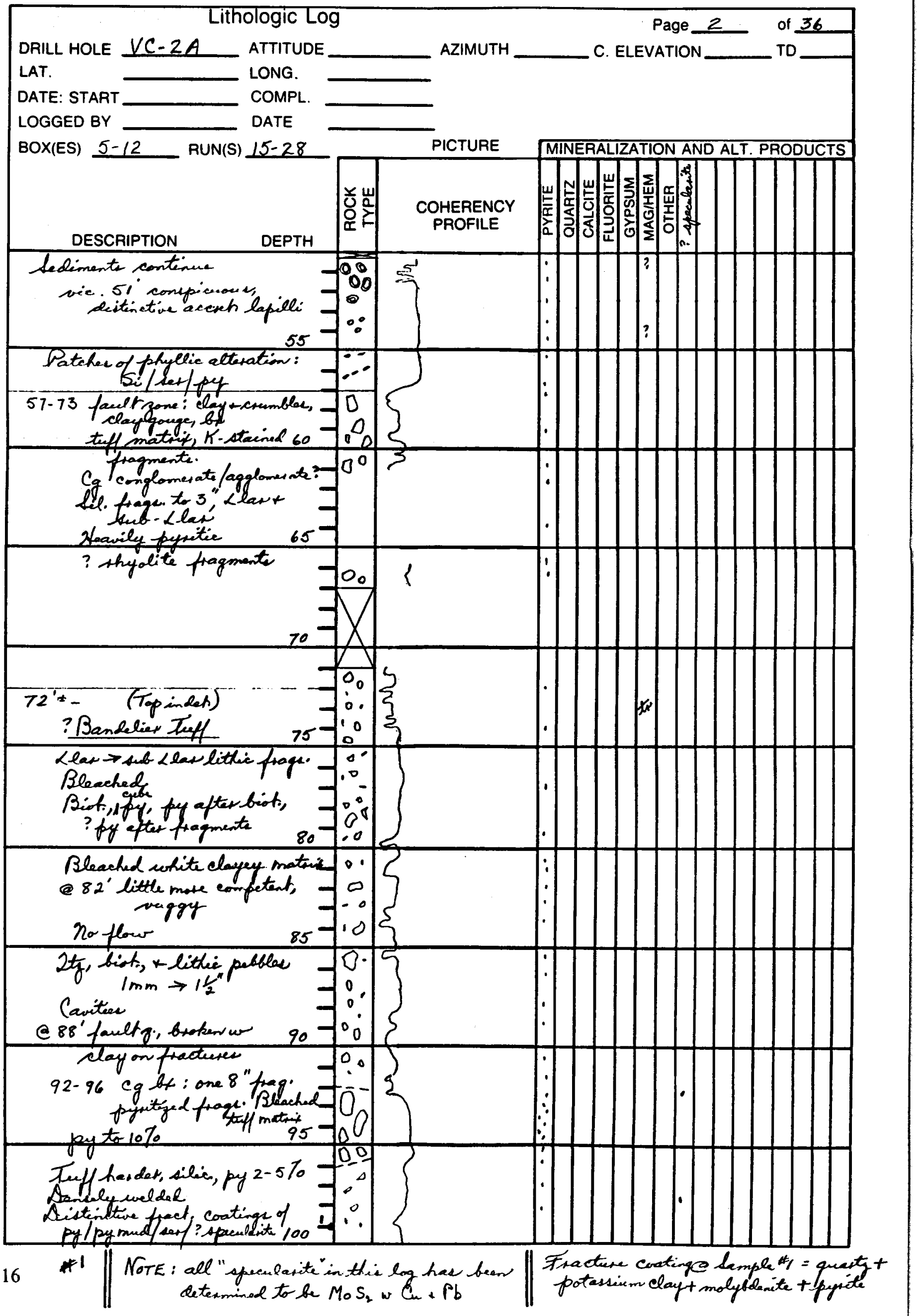




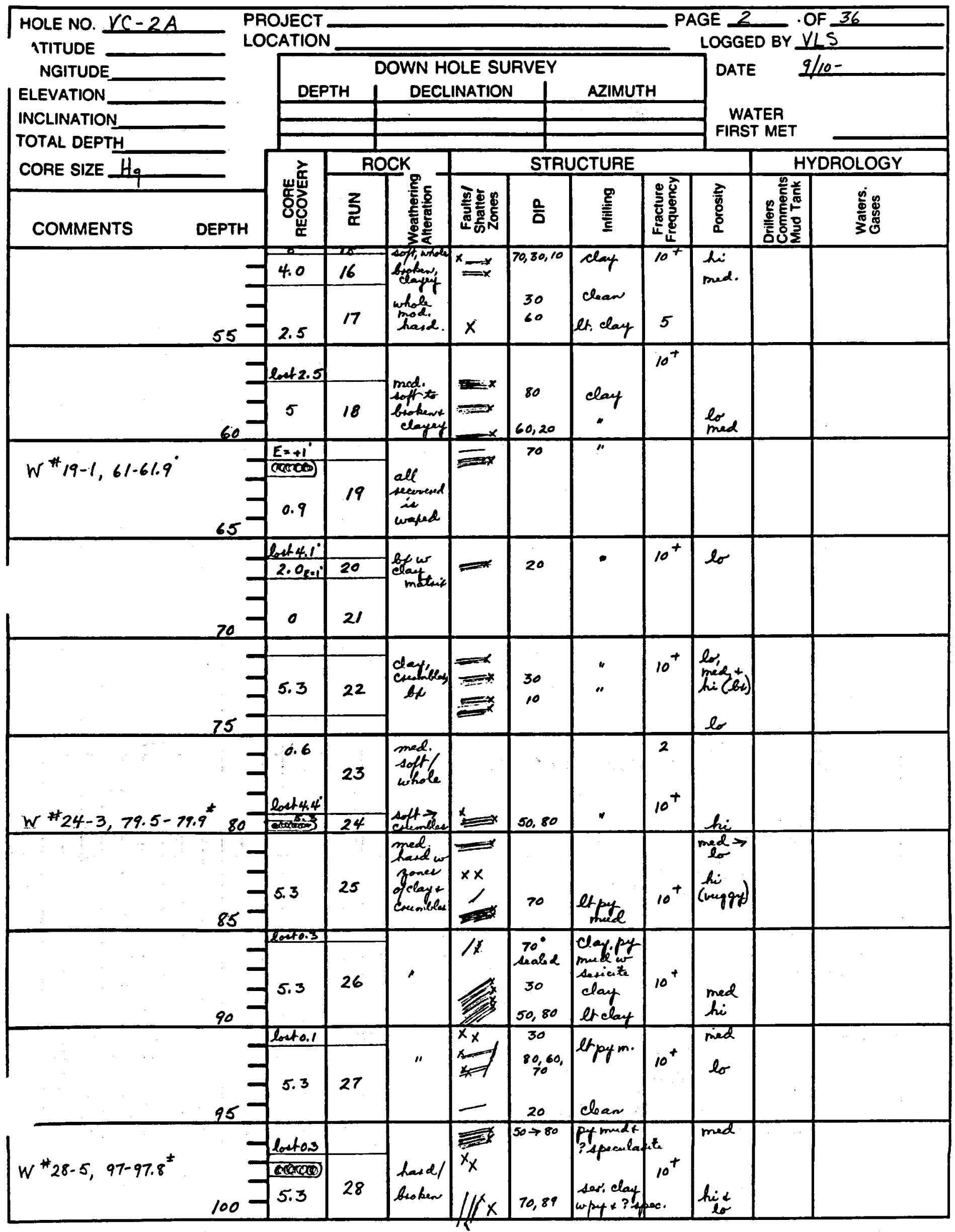




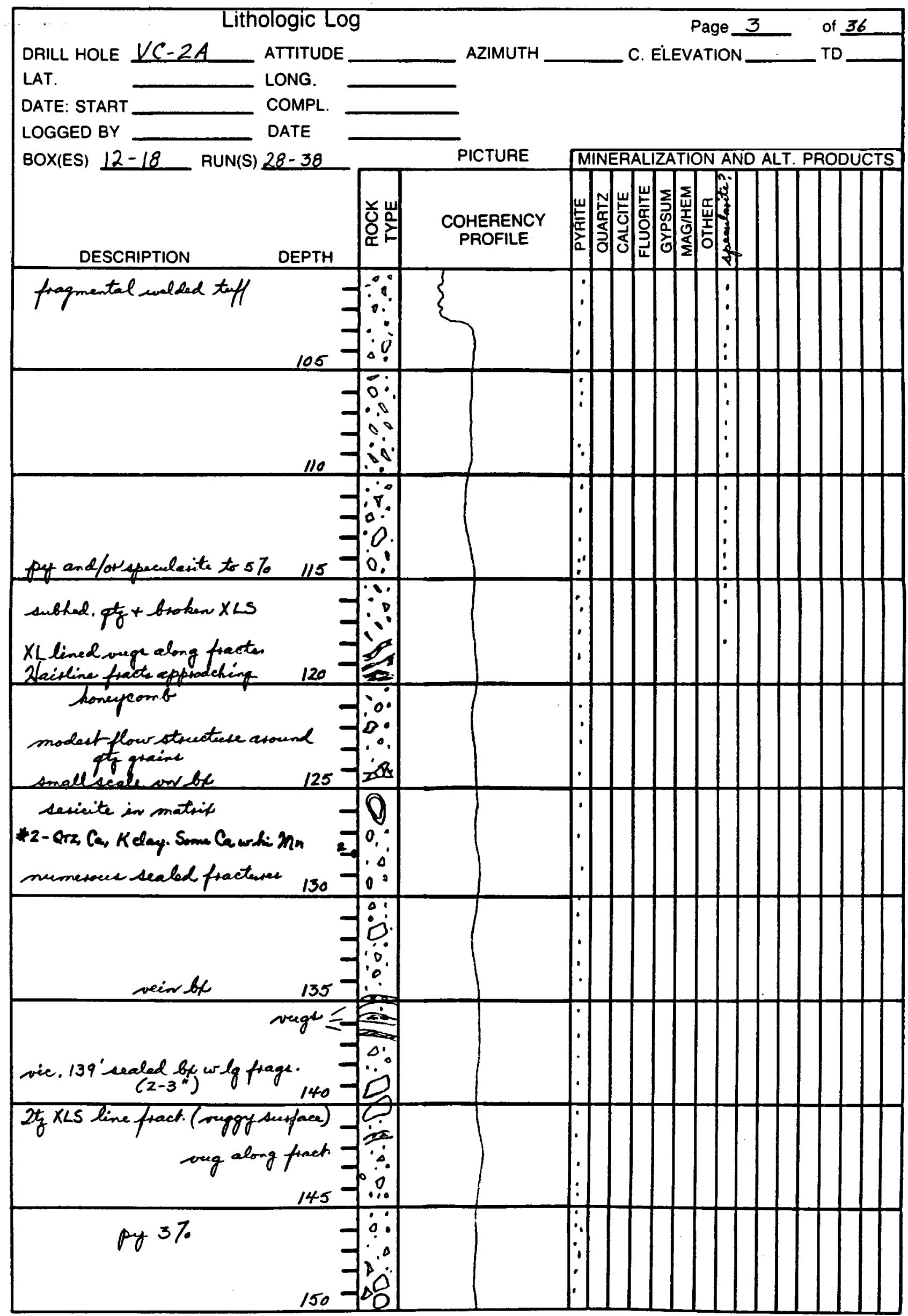




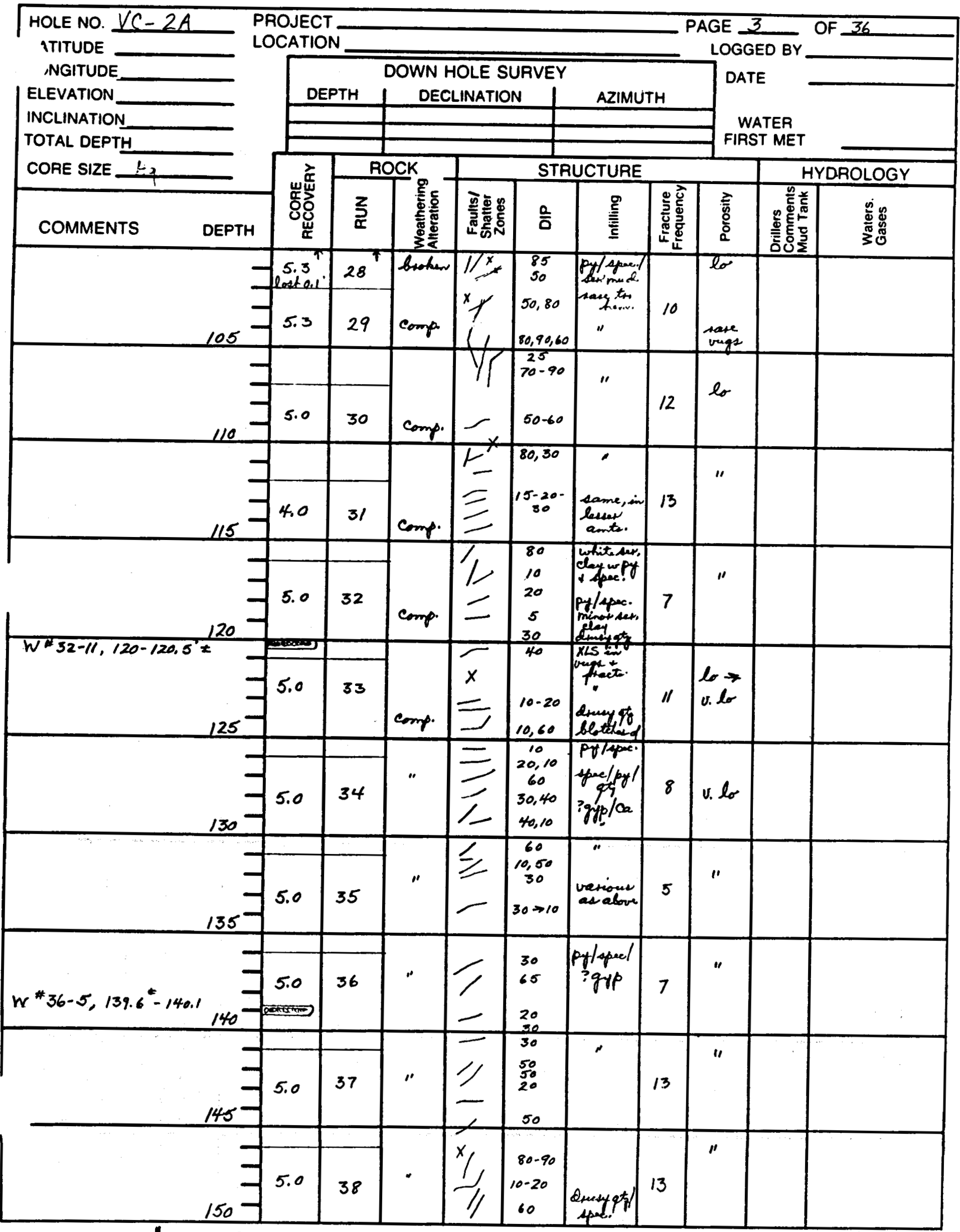

\#2 Note: No gyp. or anhydrite. Determ. to be $Q T z,+$ Caleite + Kelay; Ce urh $M n$ 


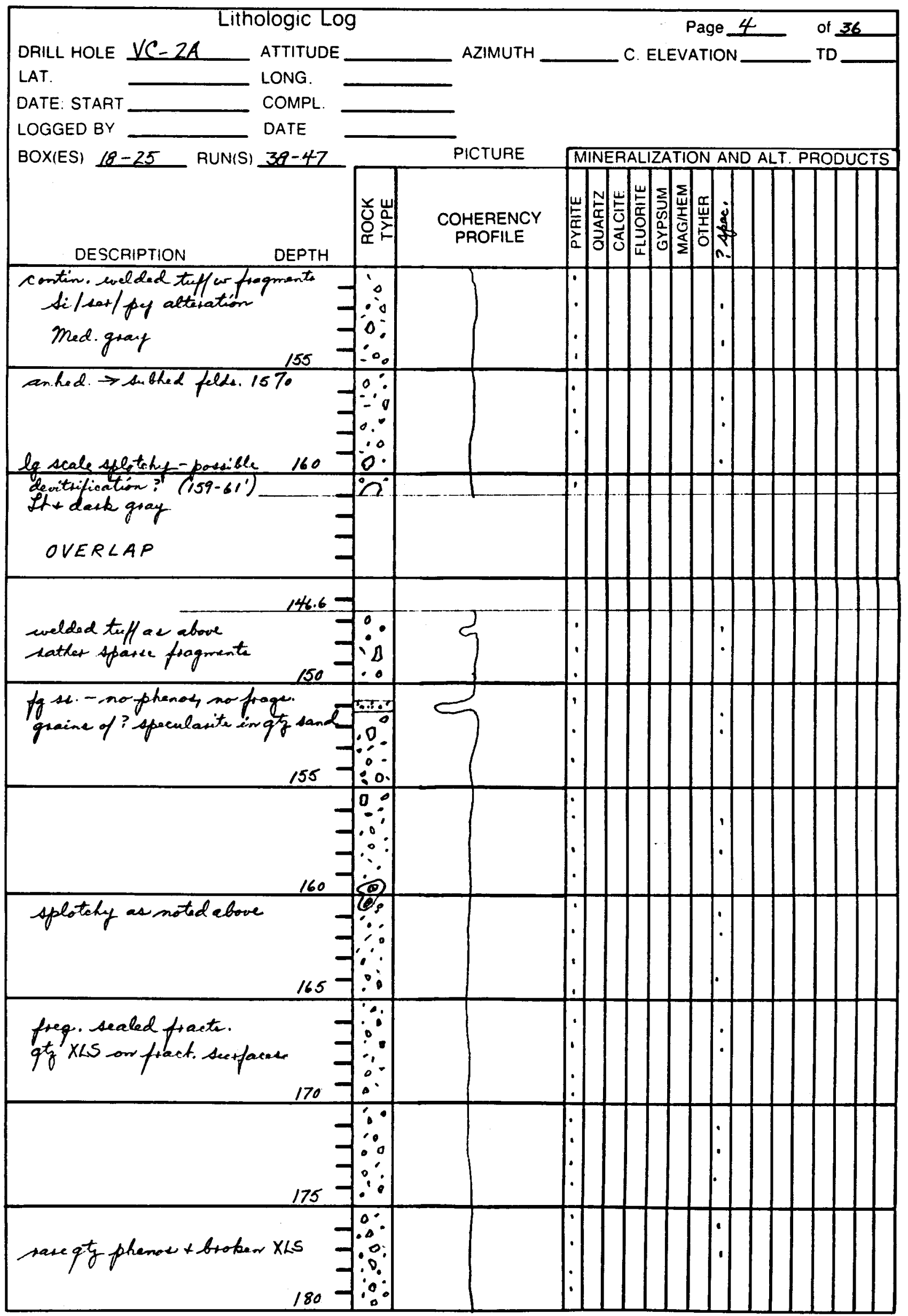




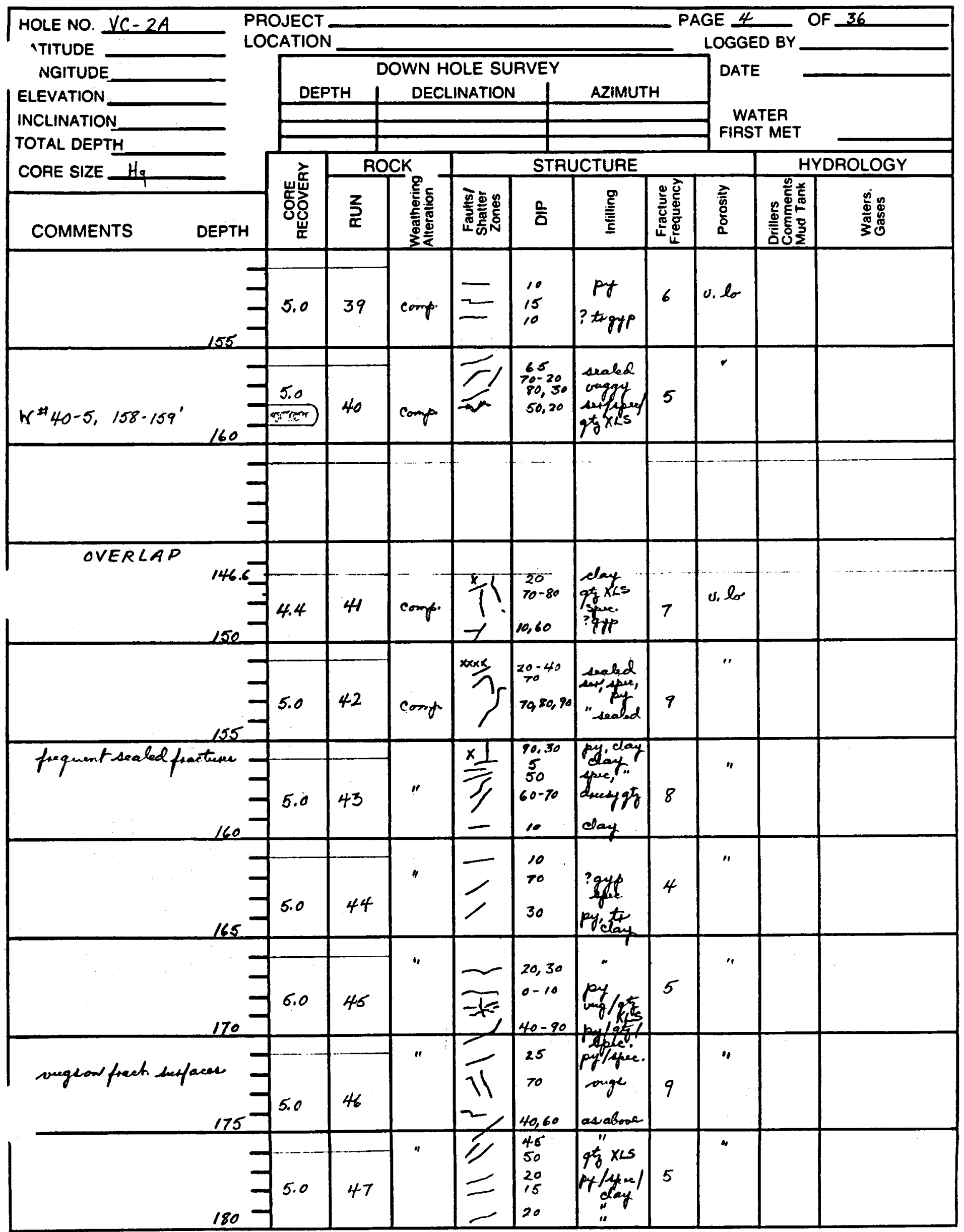




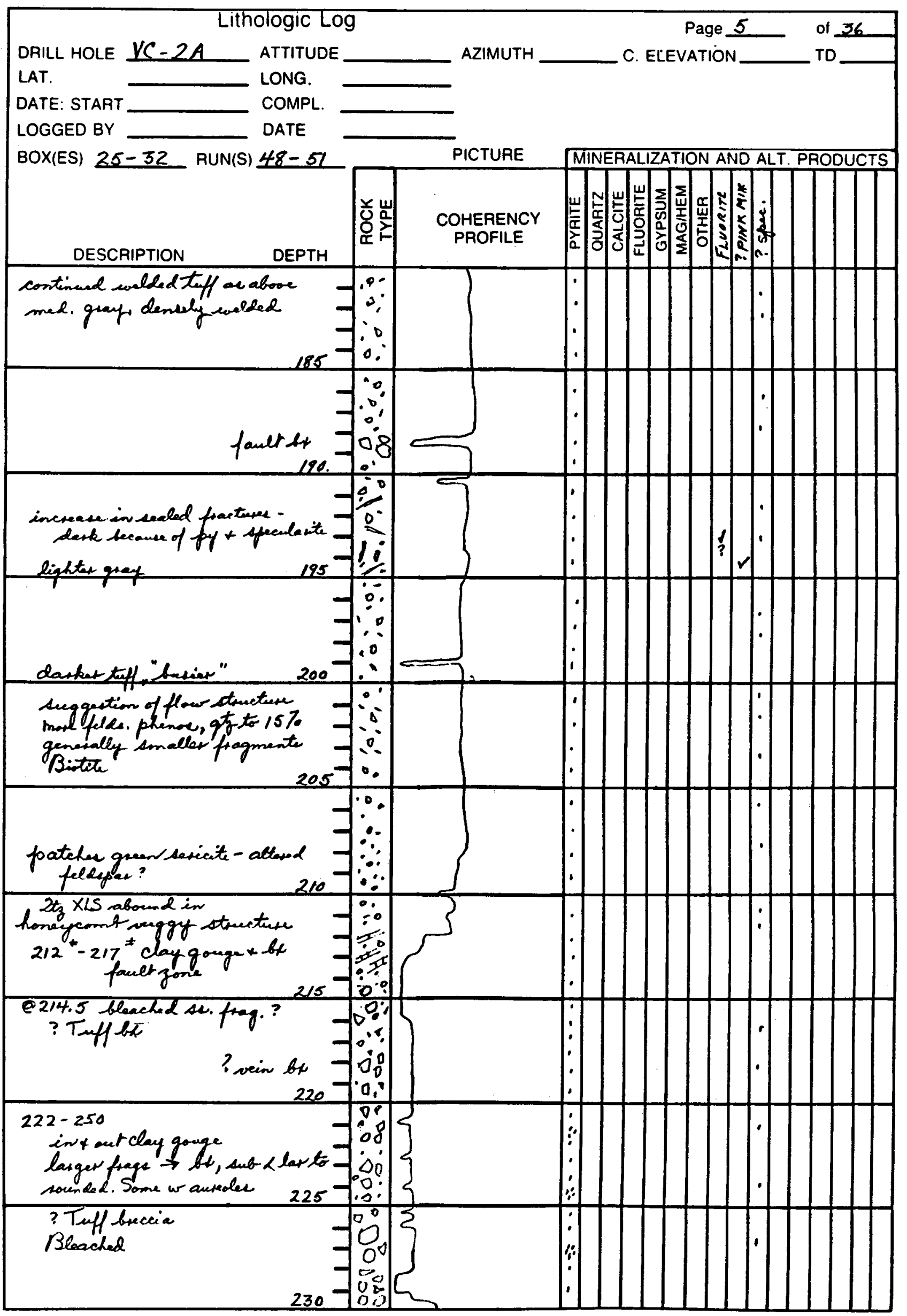




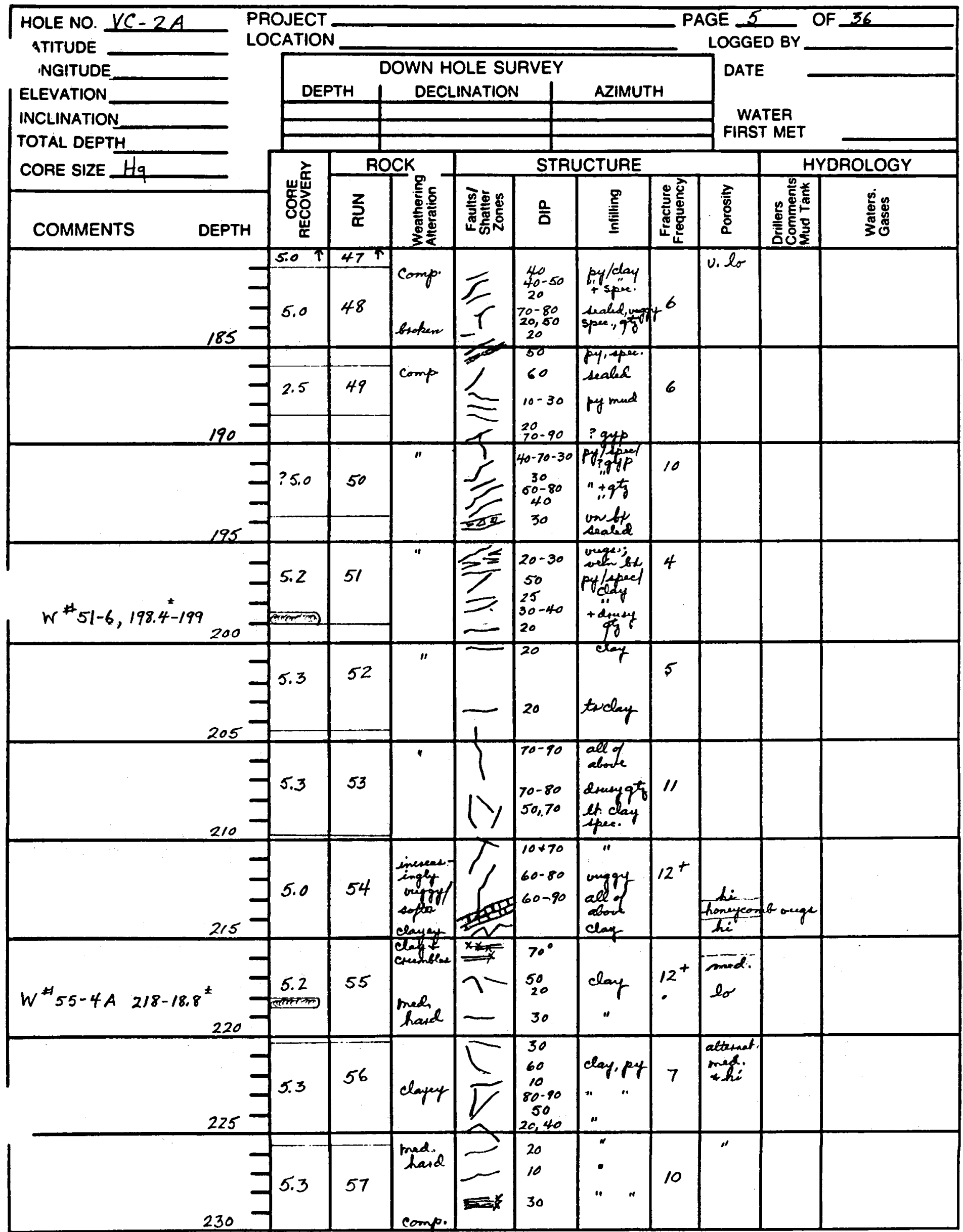




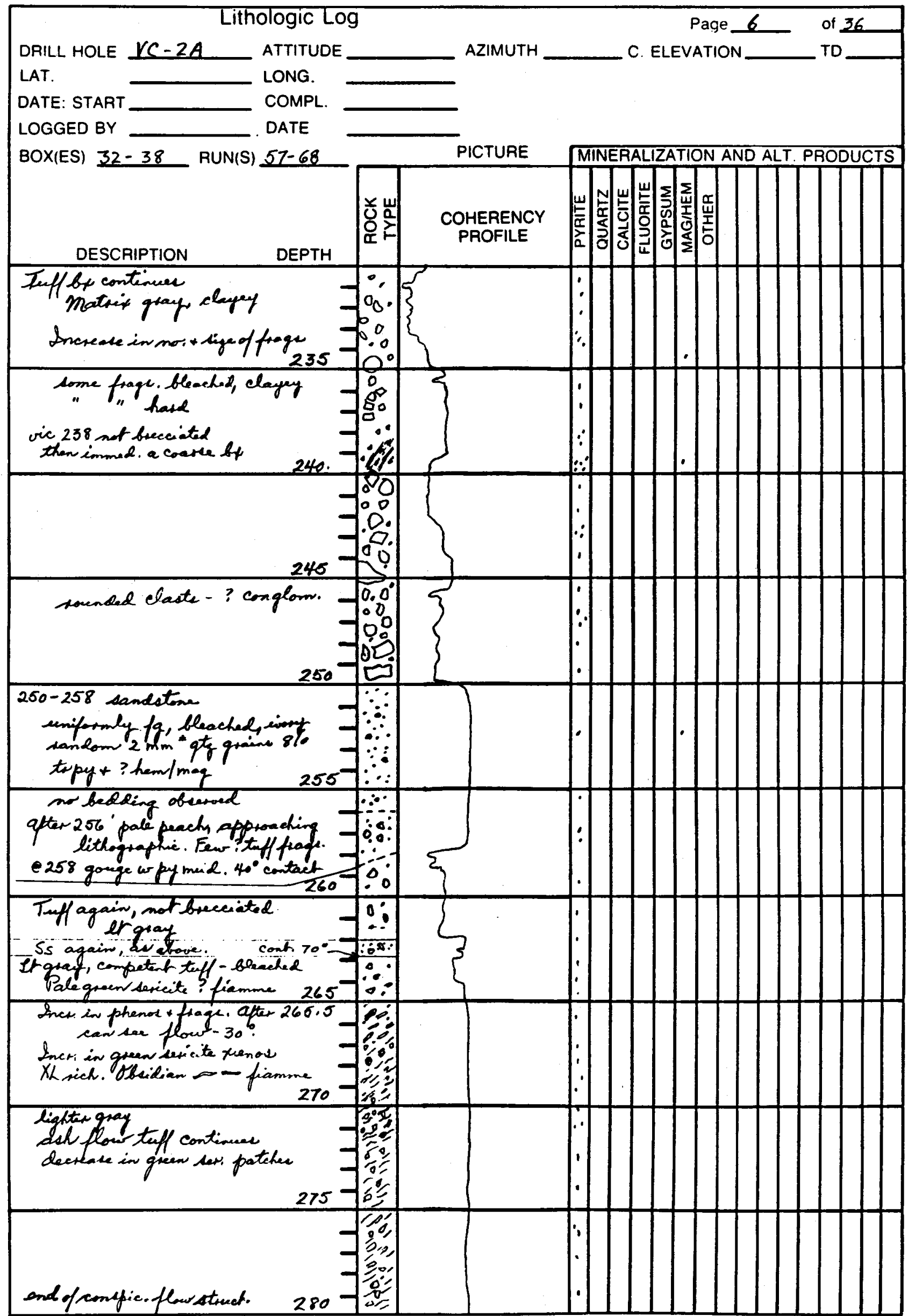




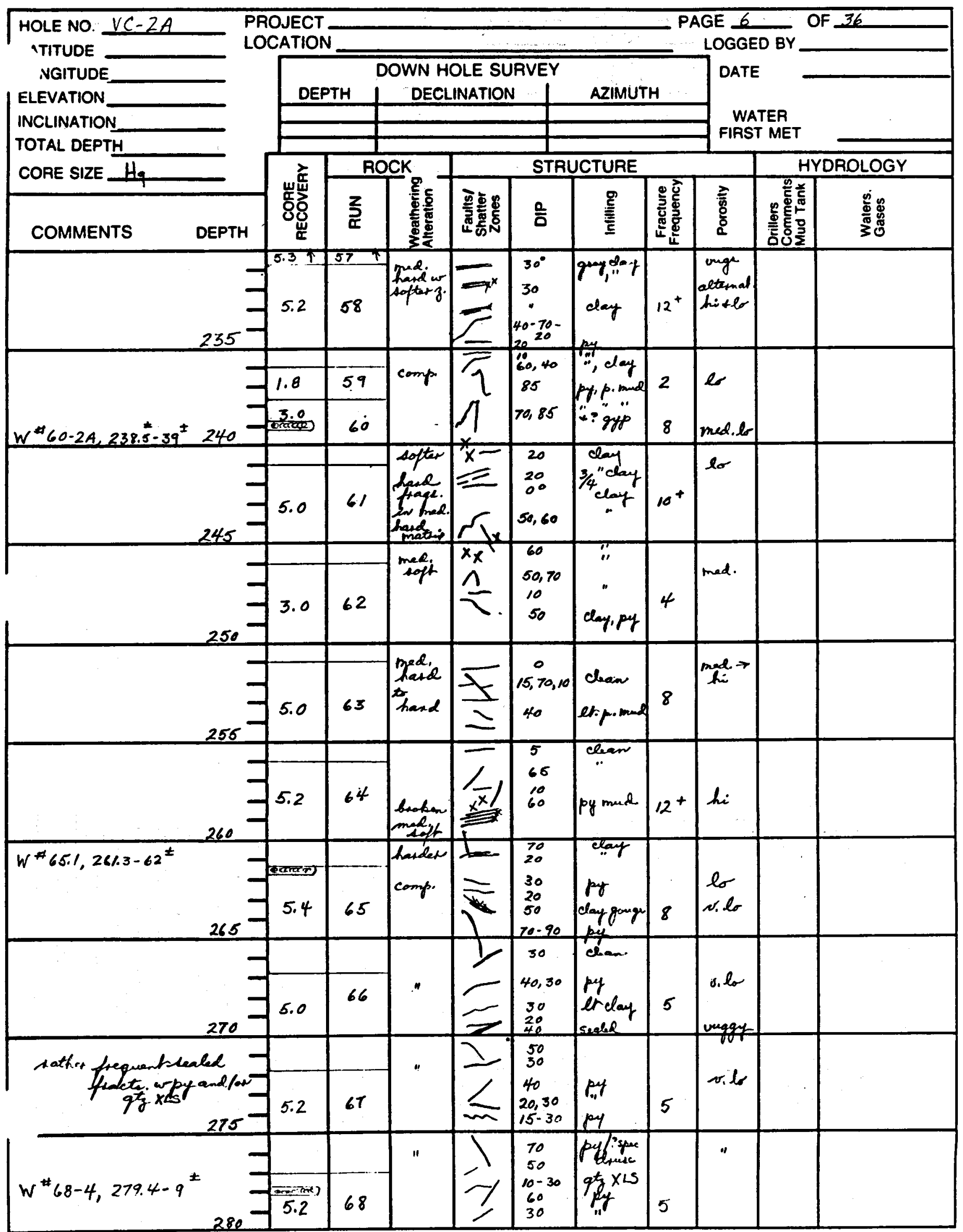




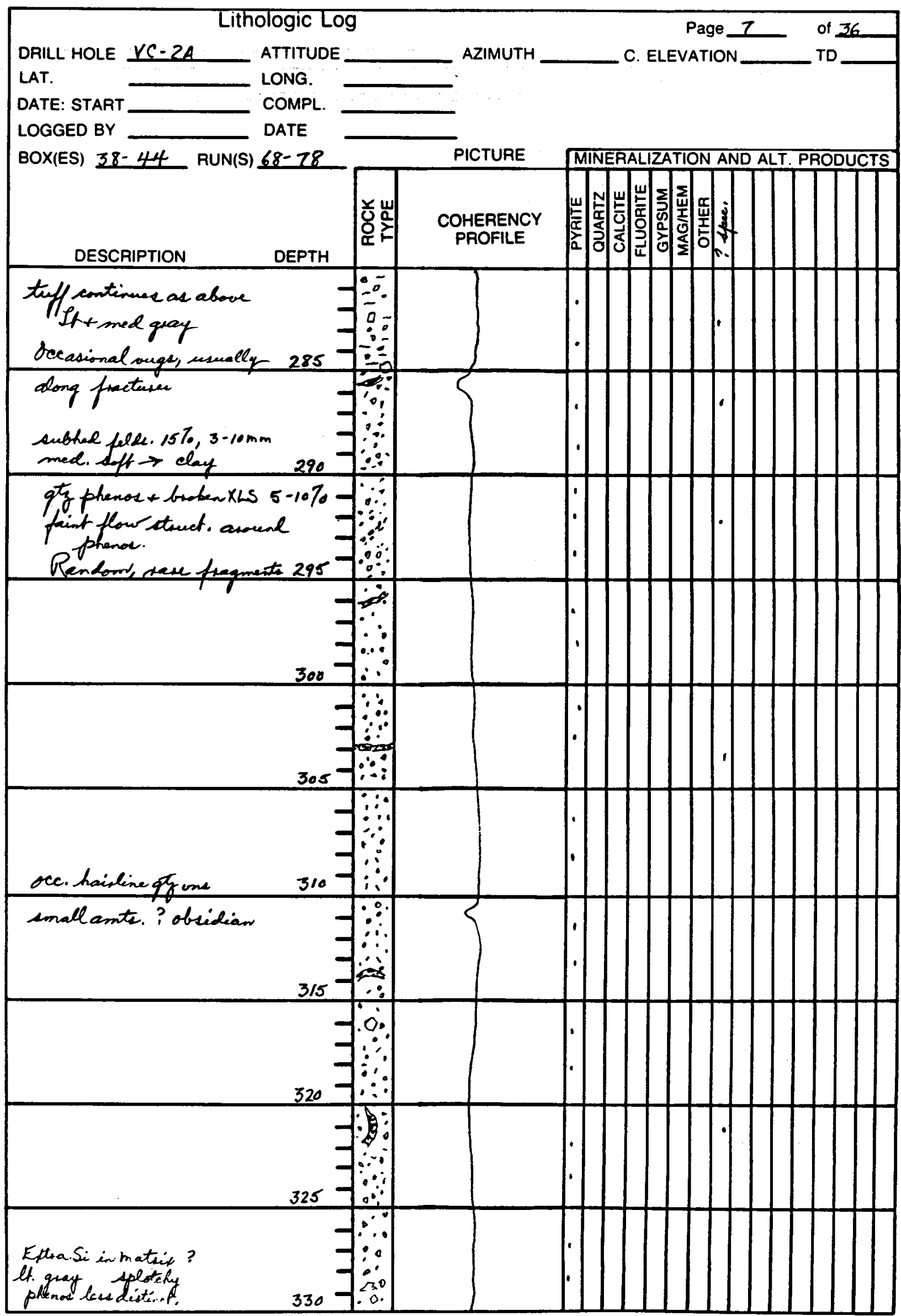




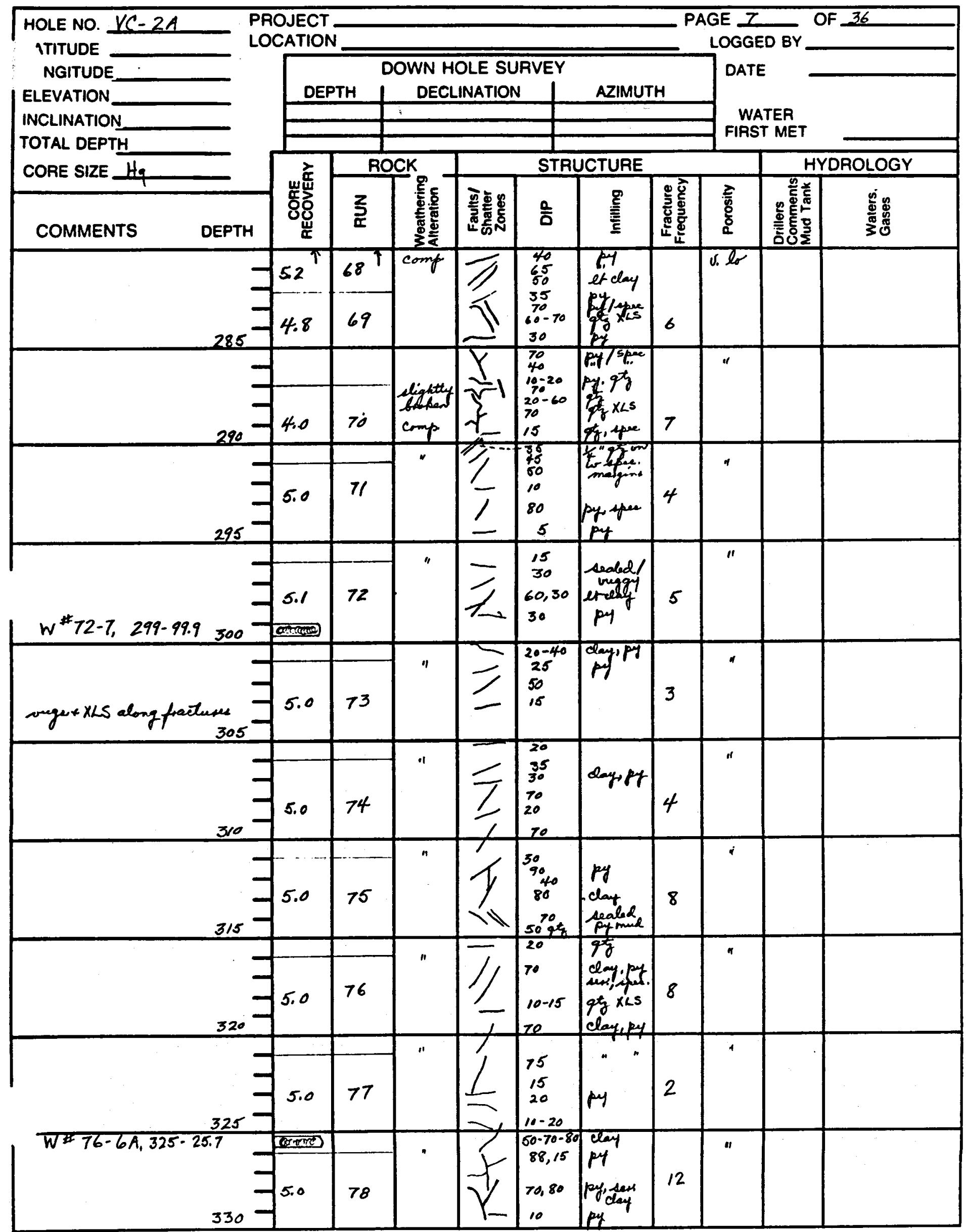




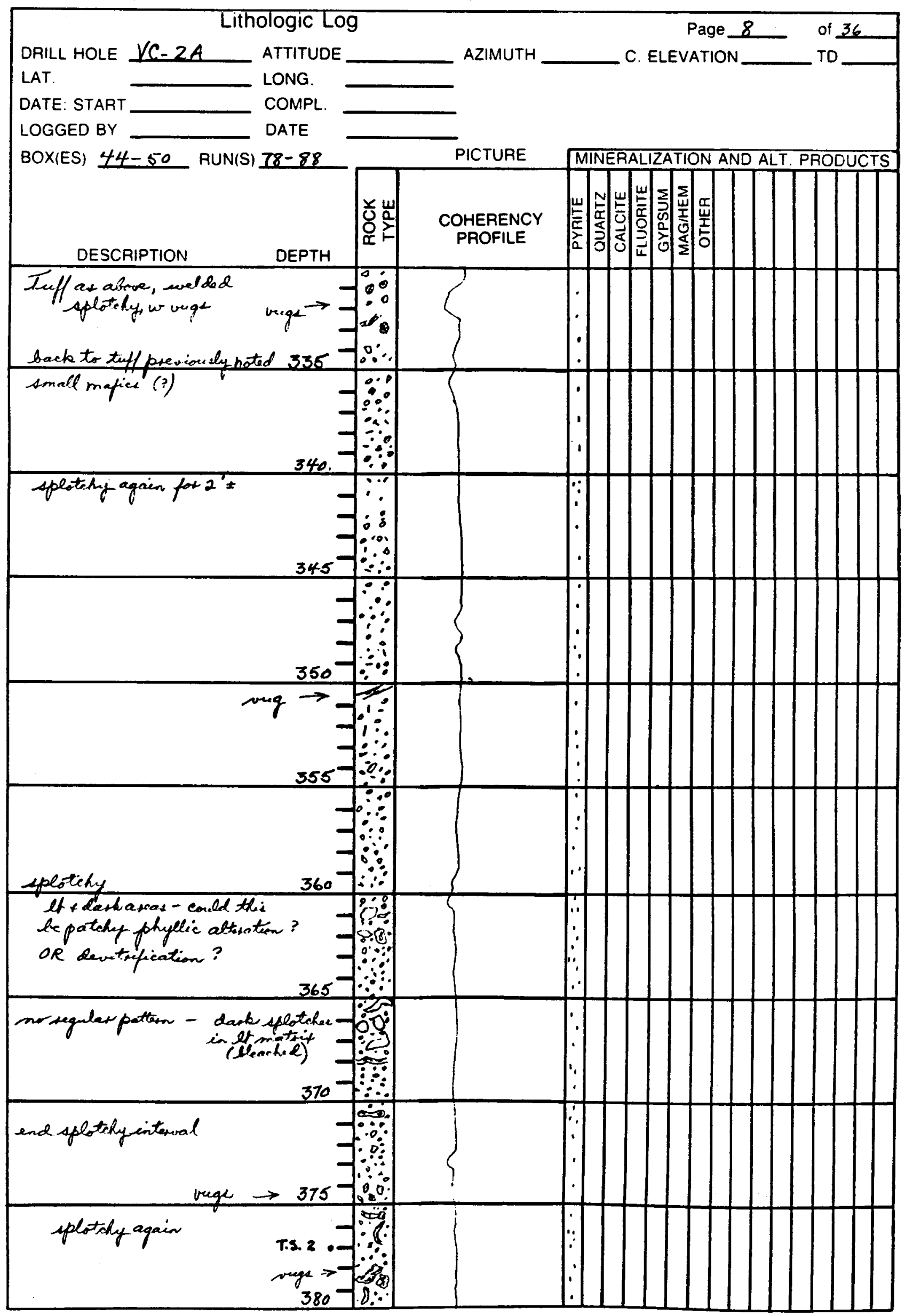




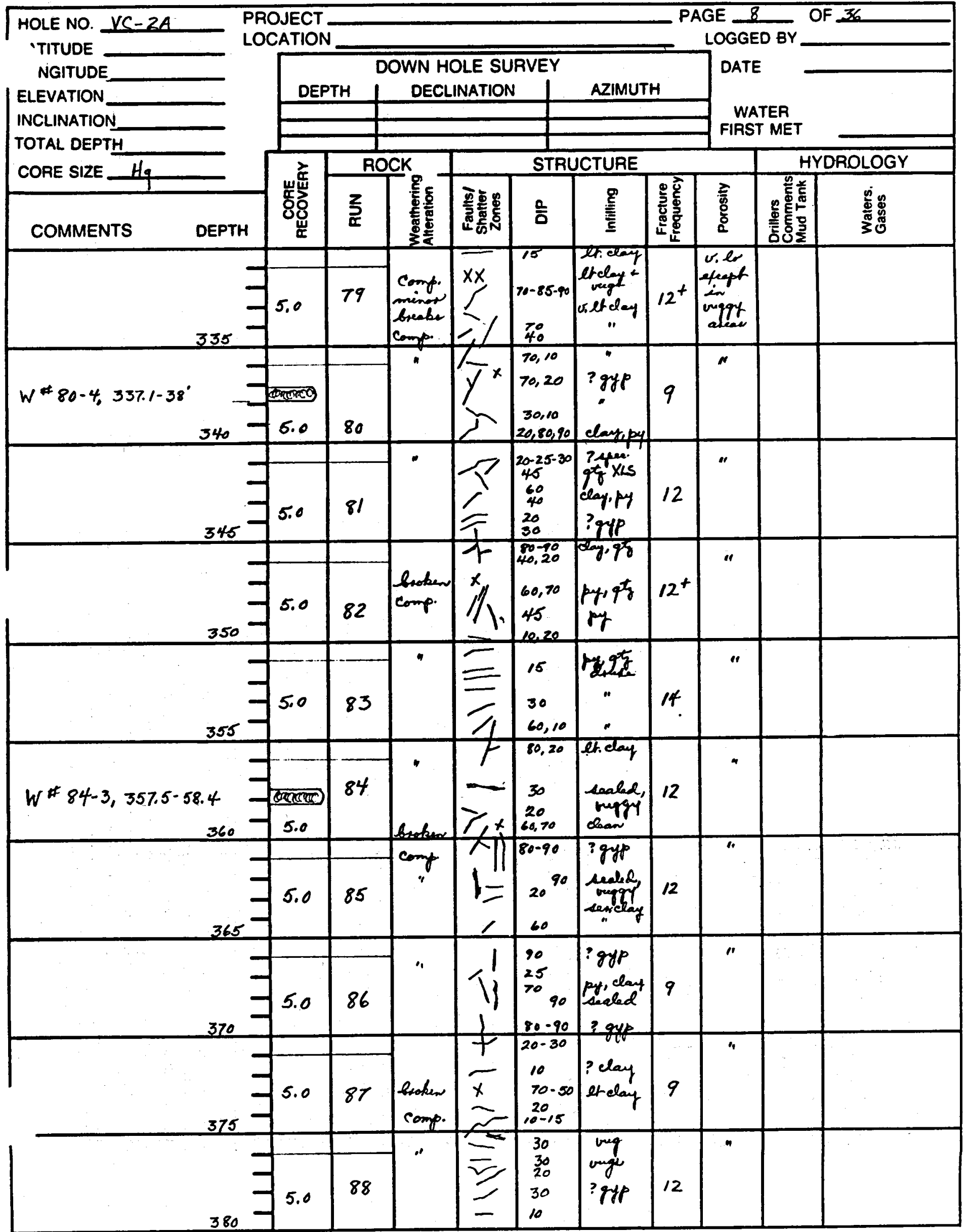




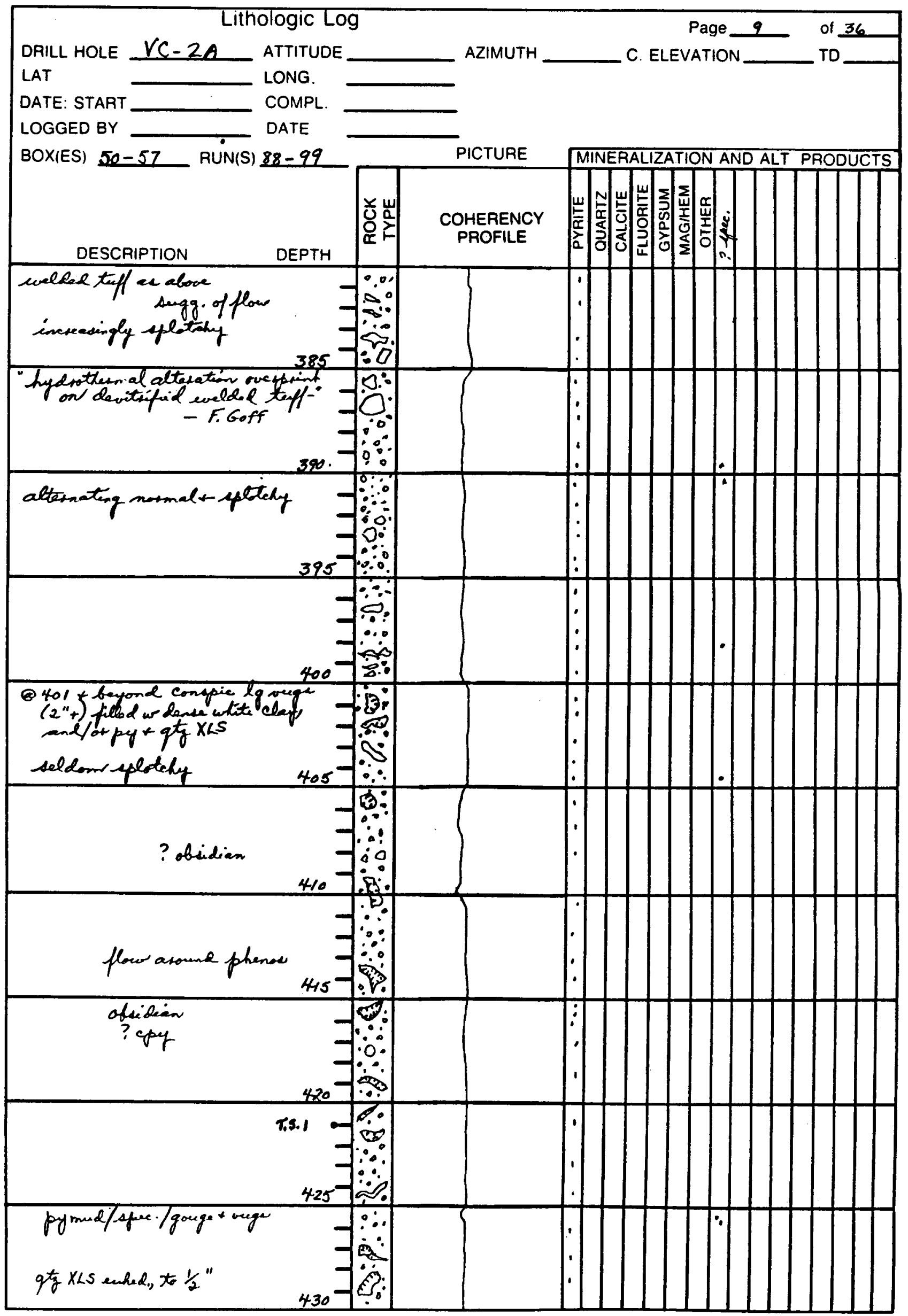




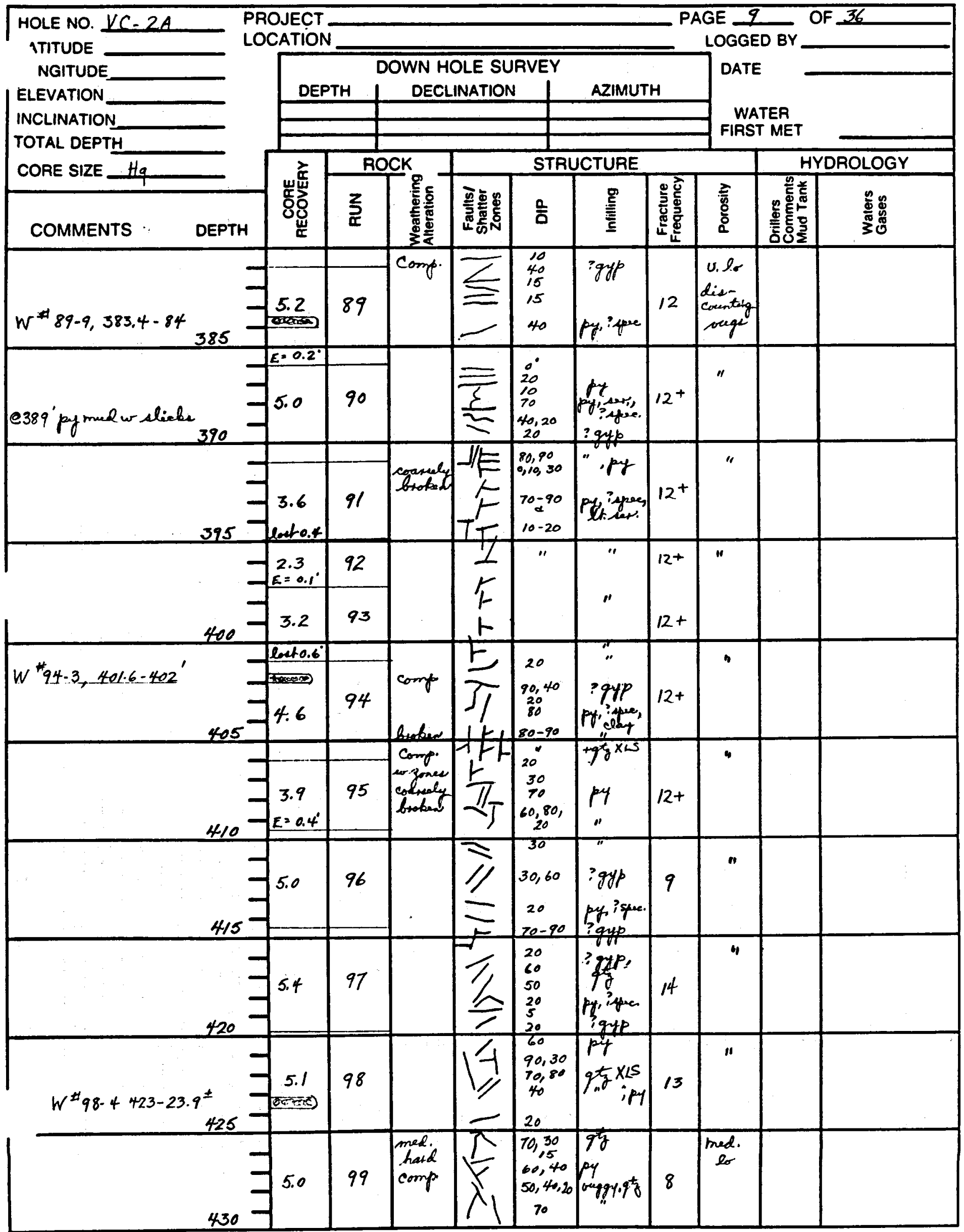




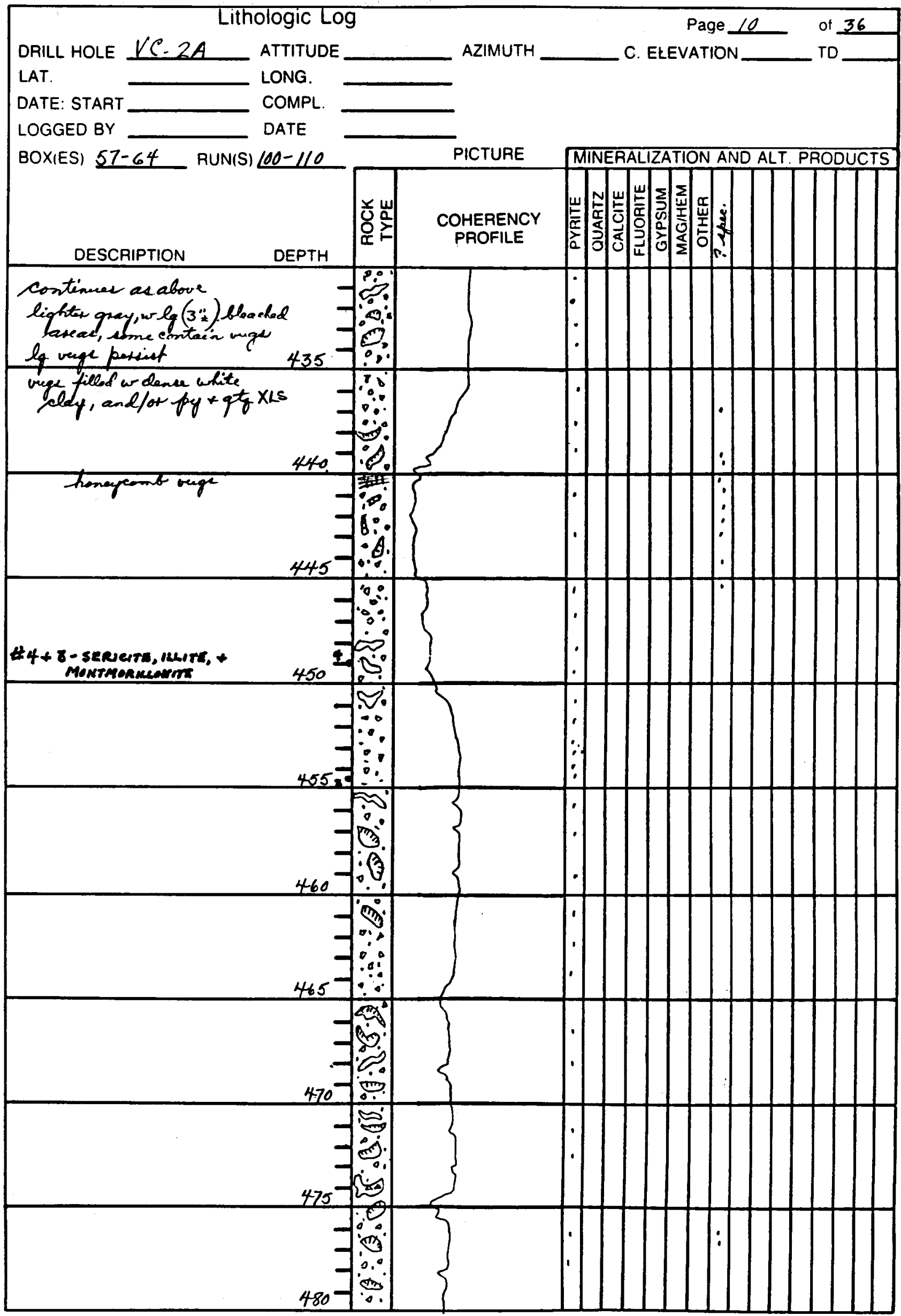




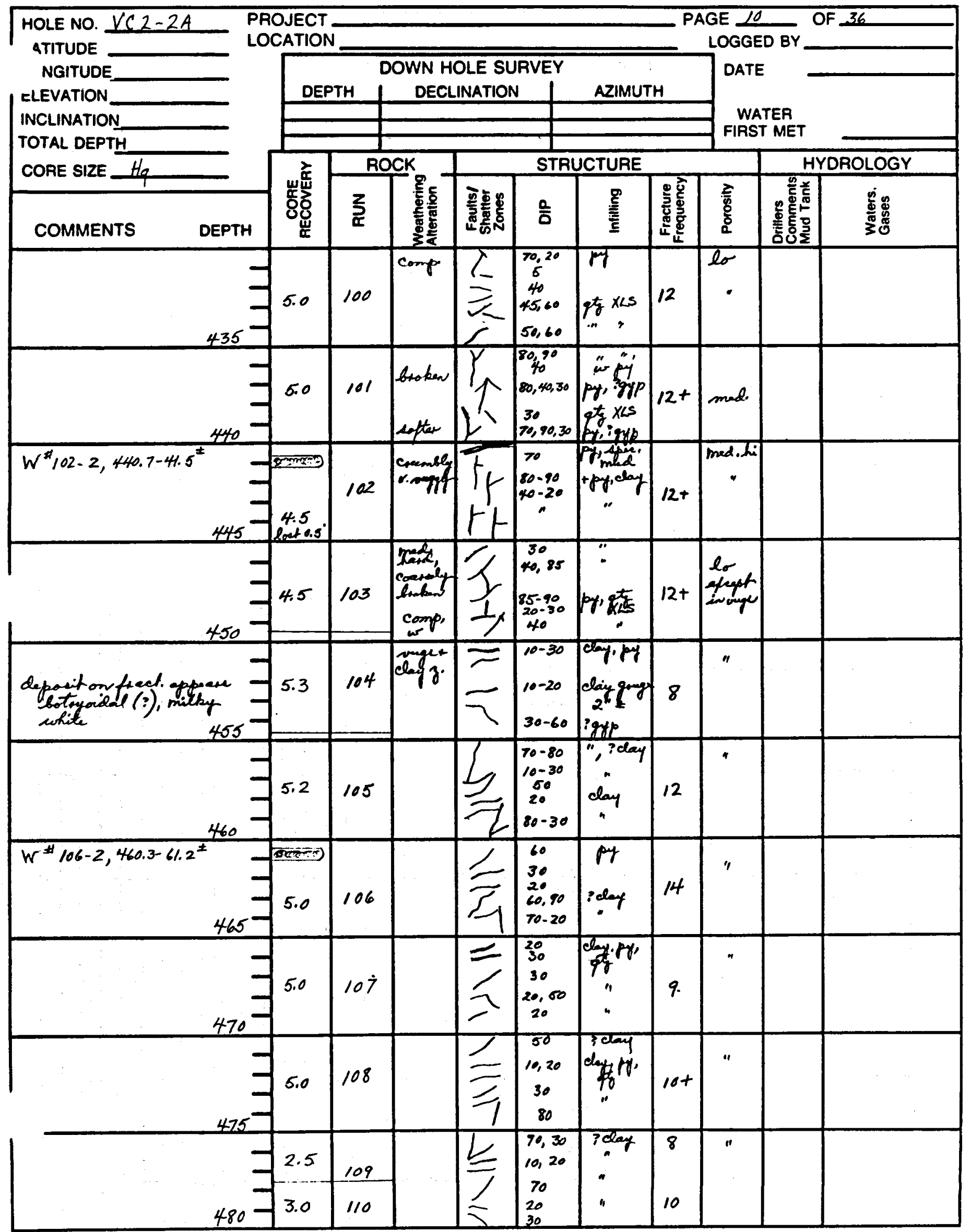




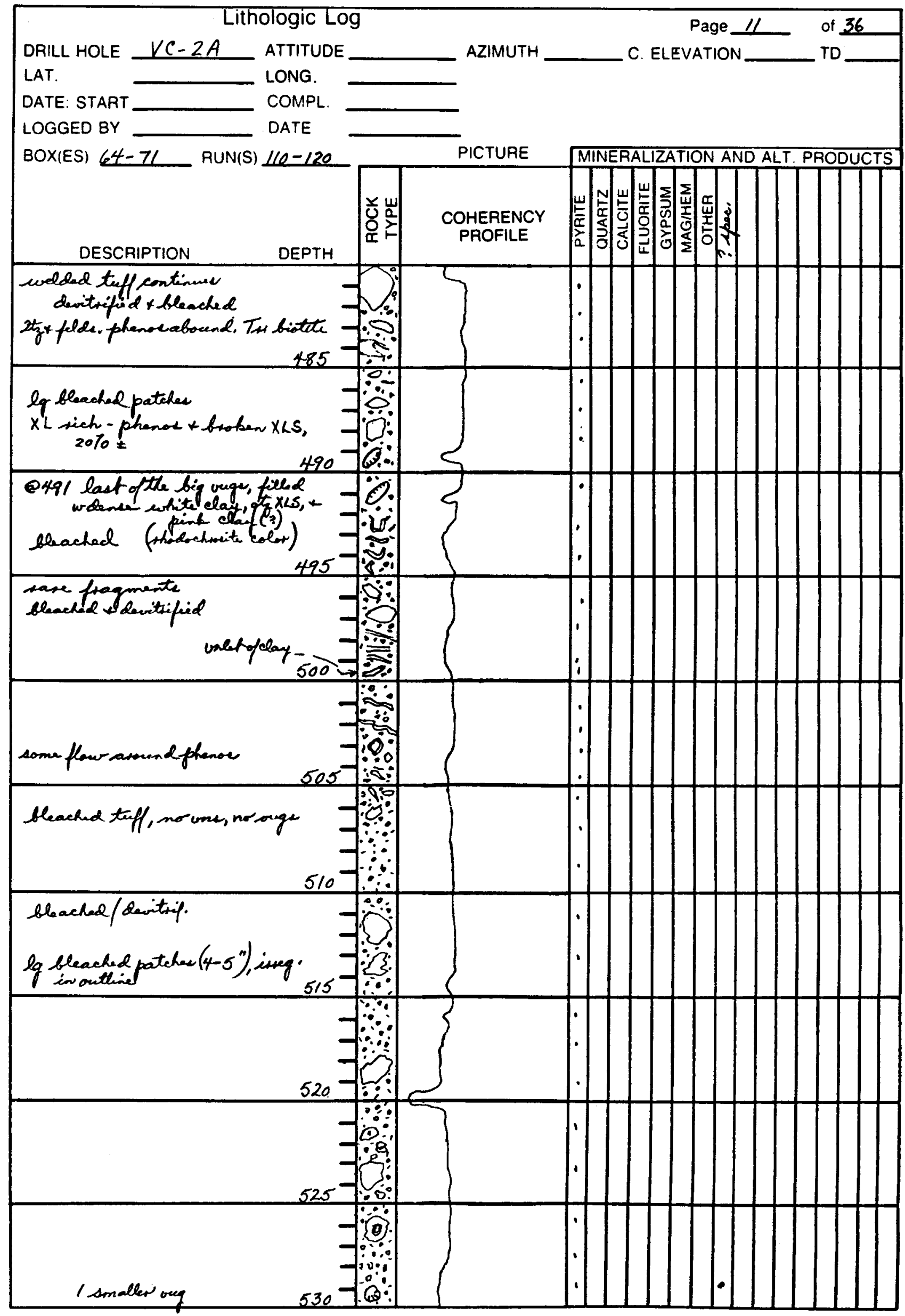




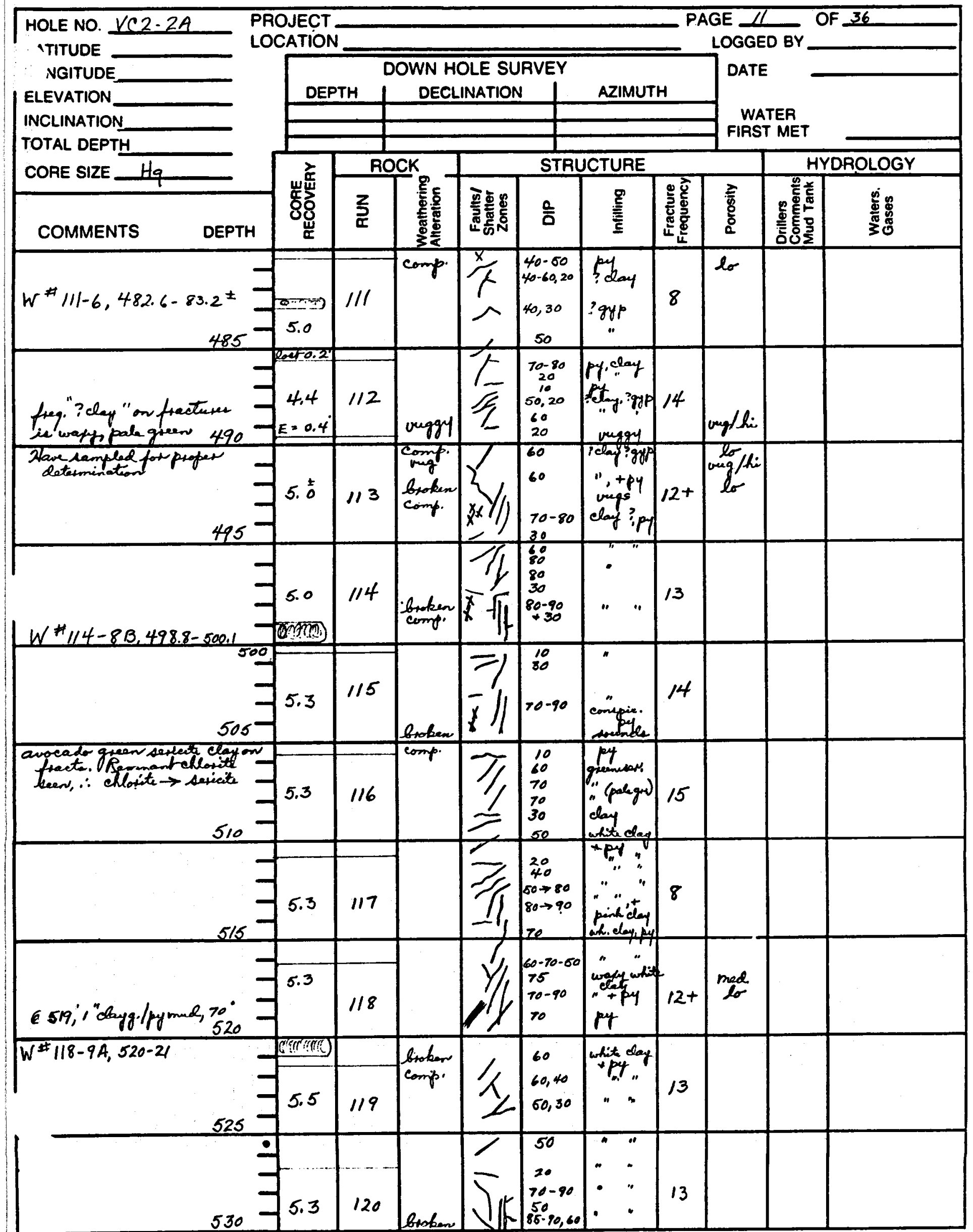




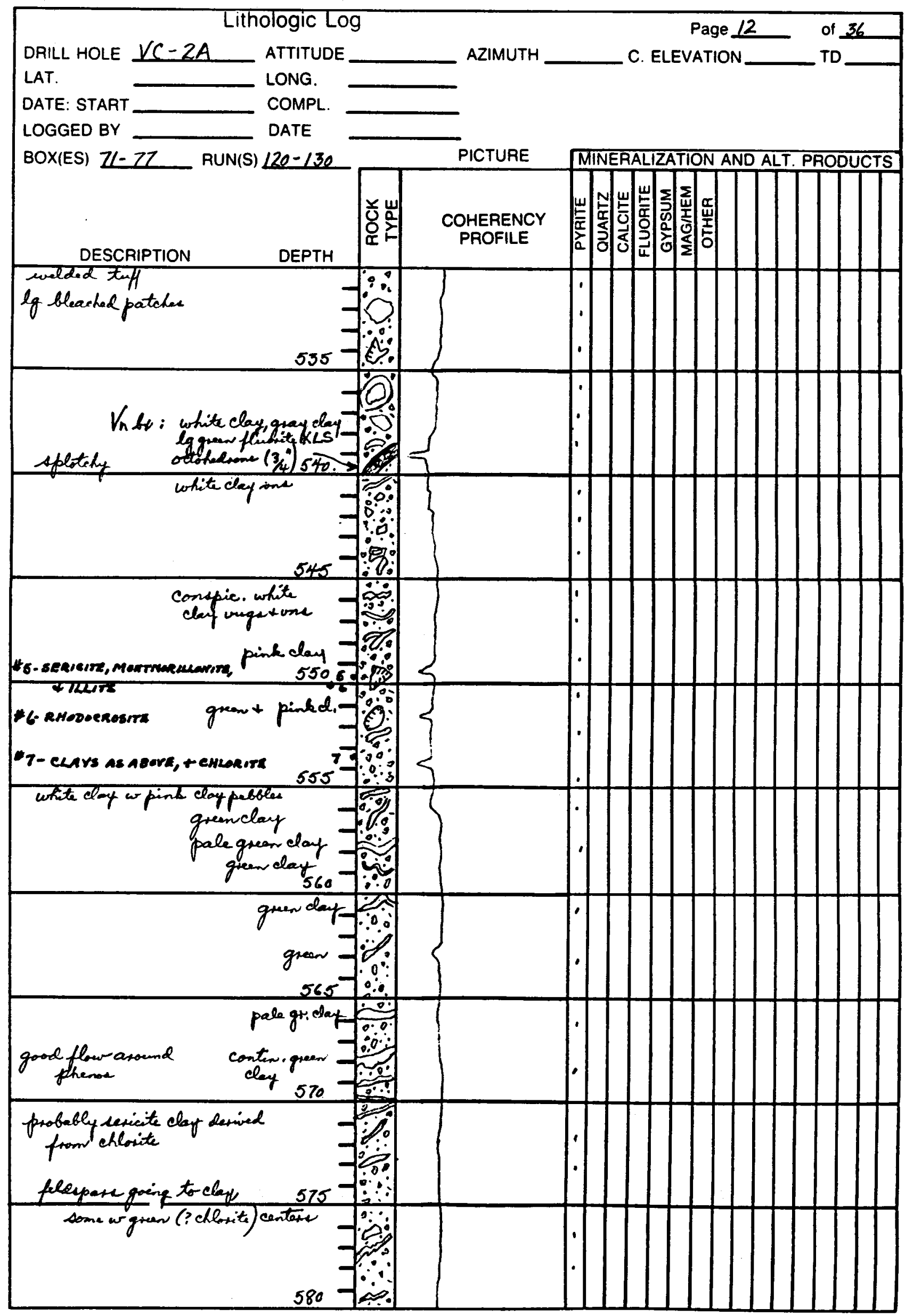




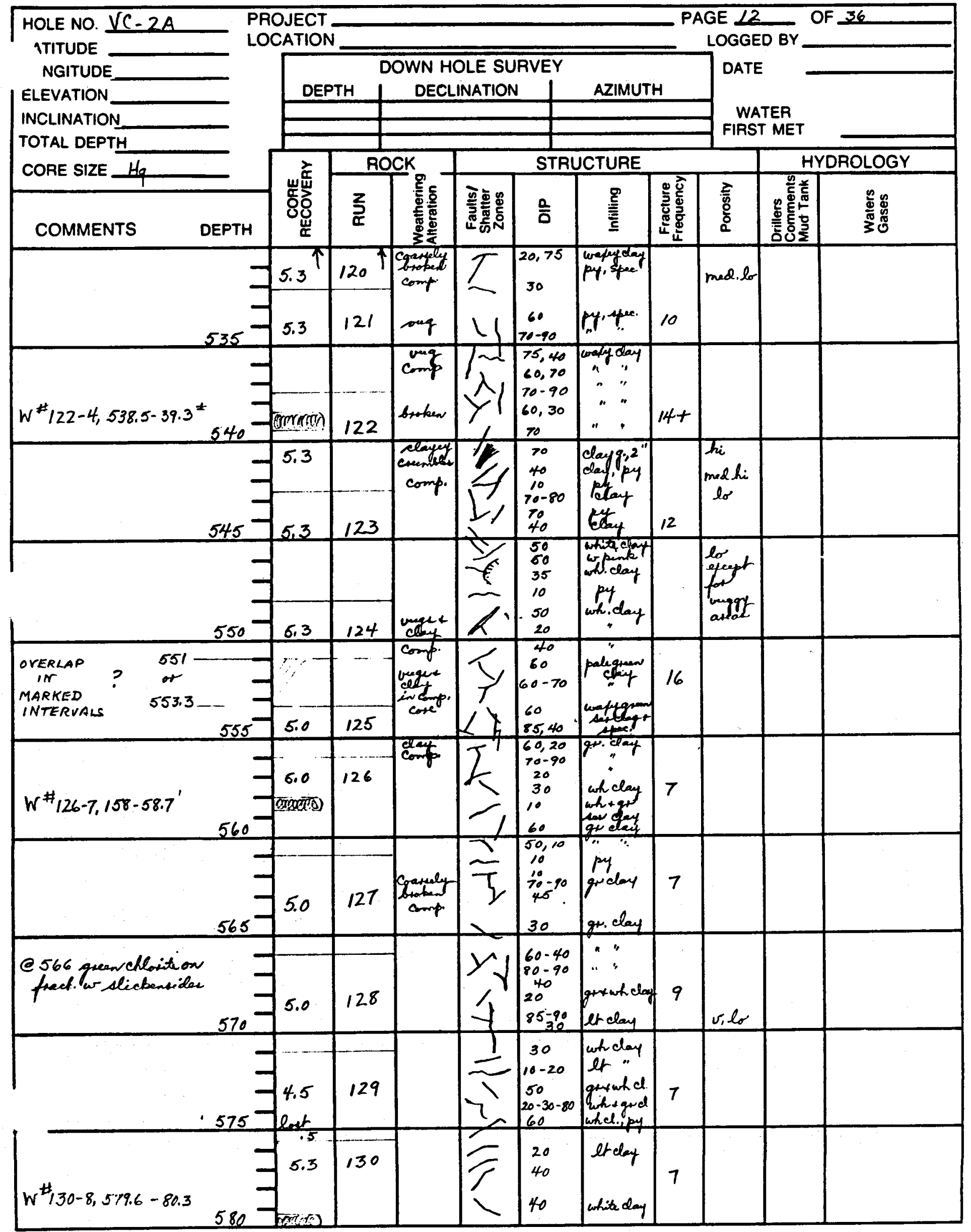




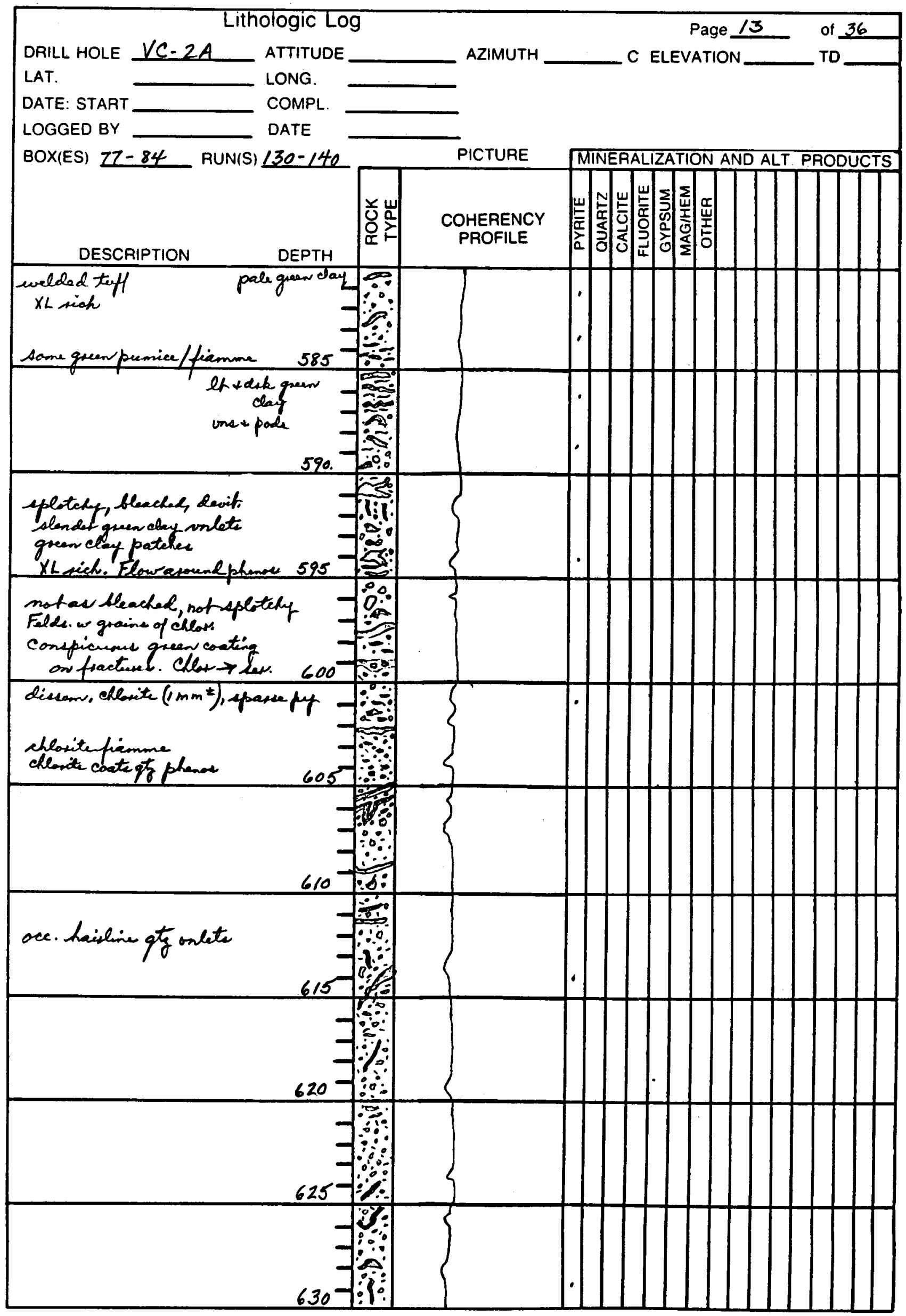




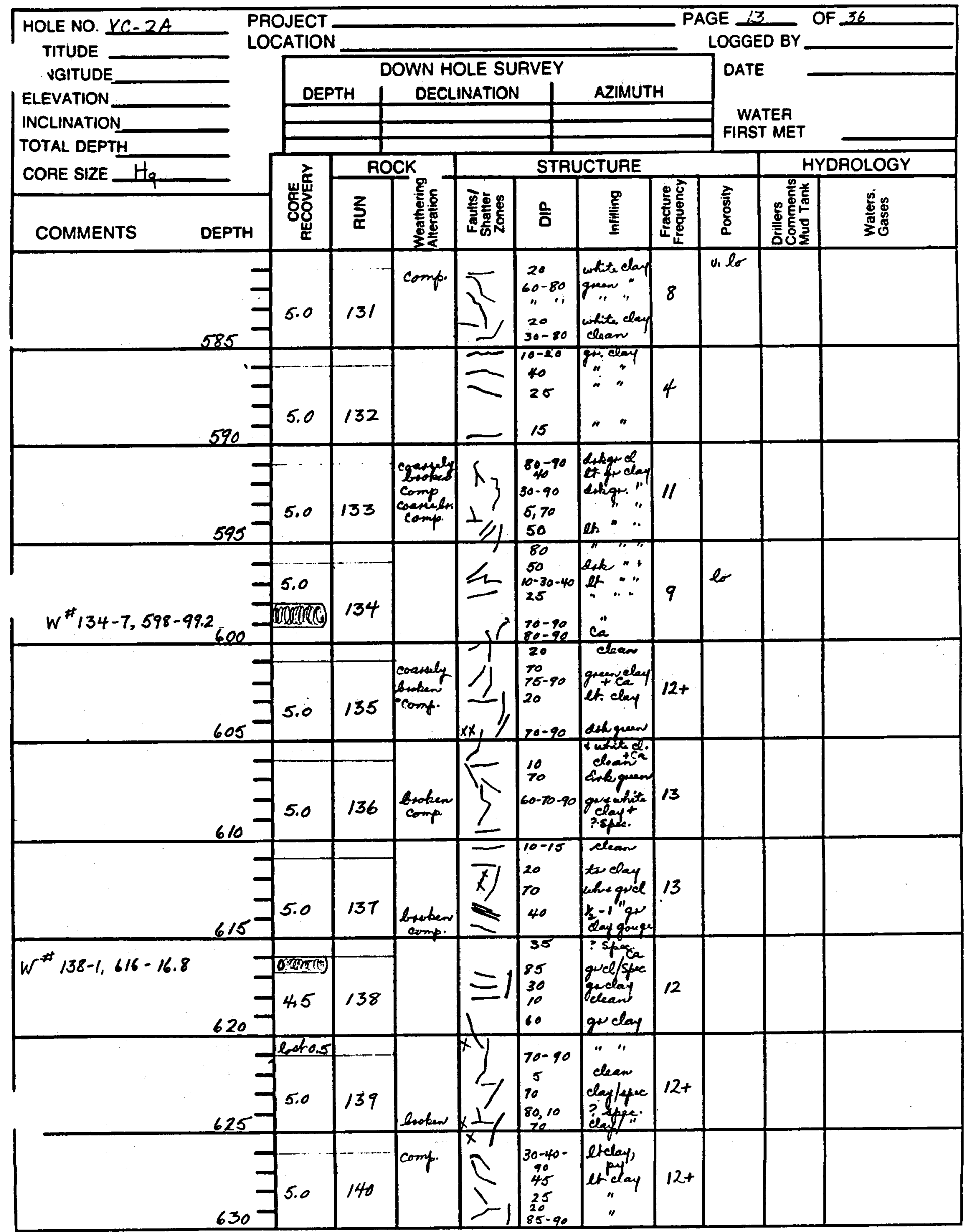




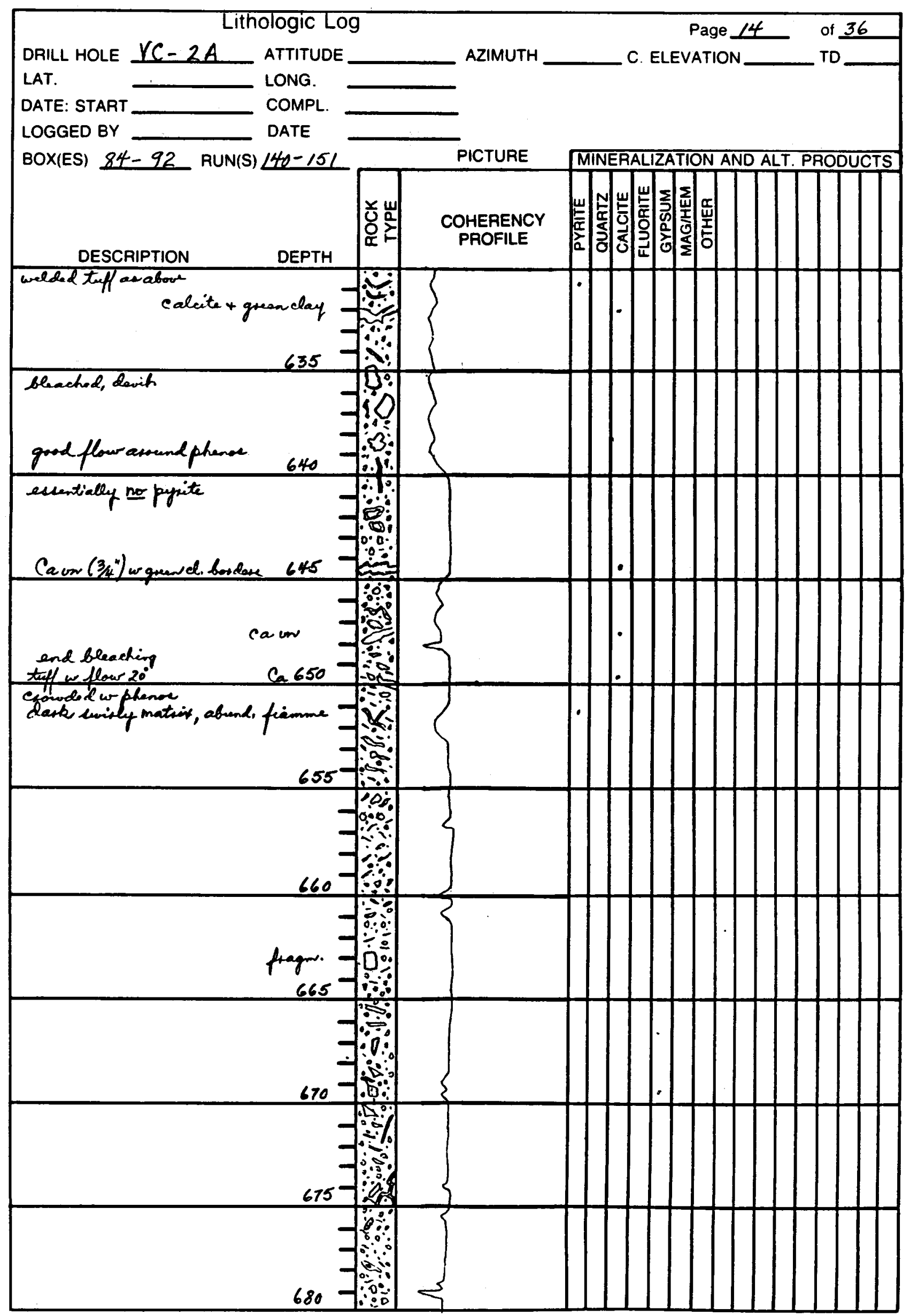




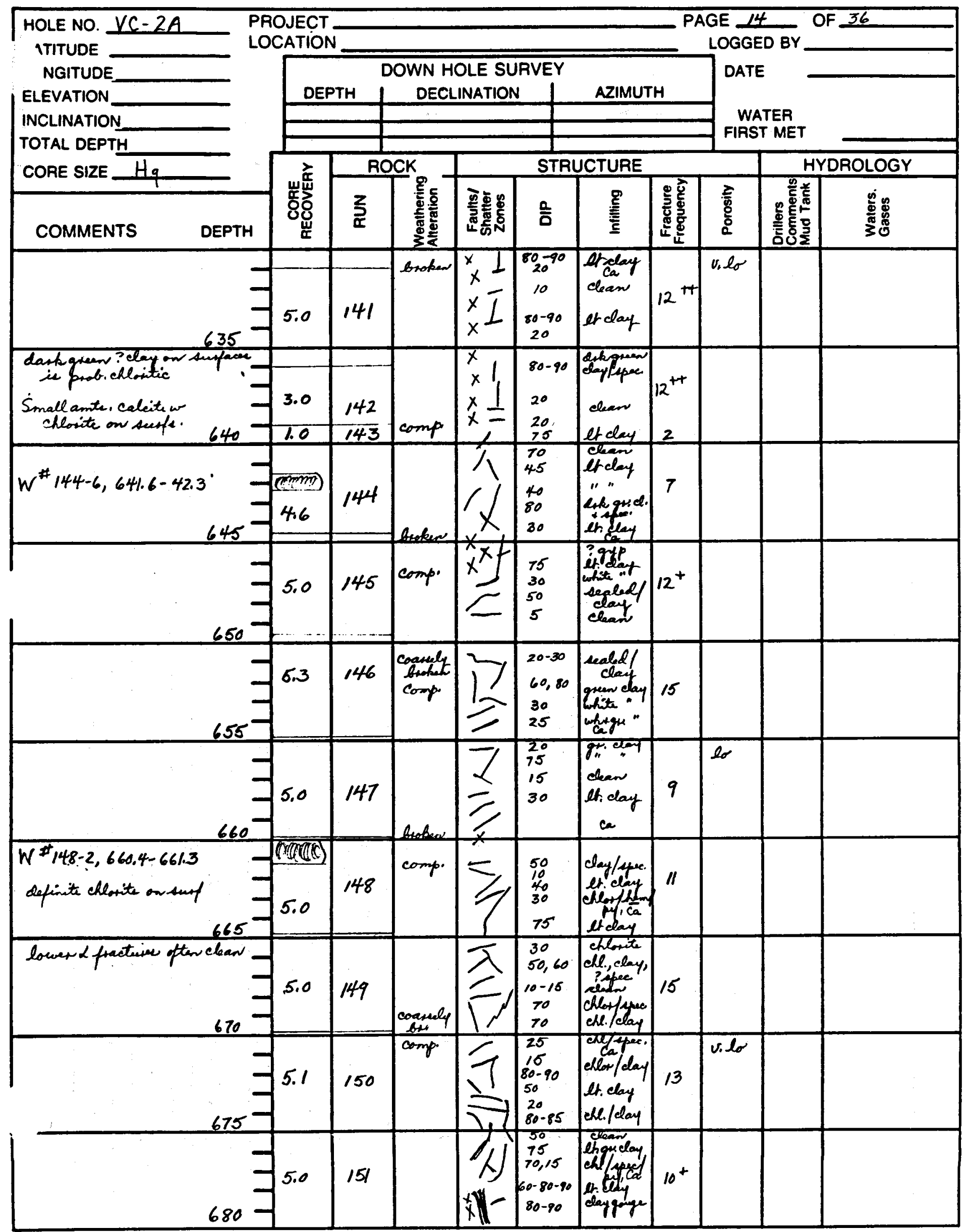




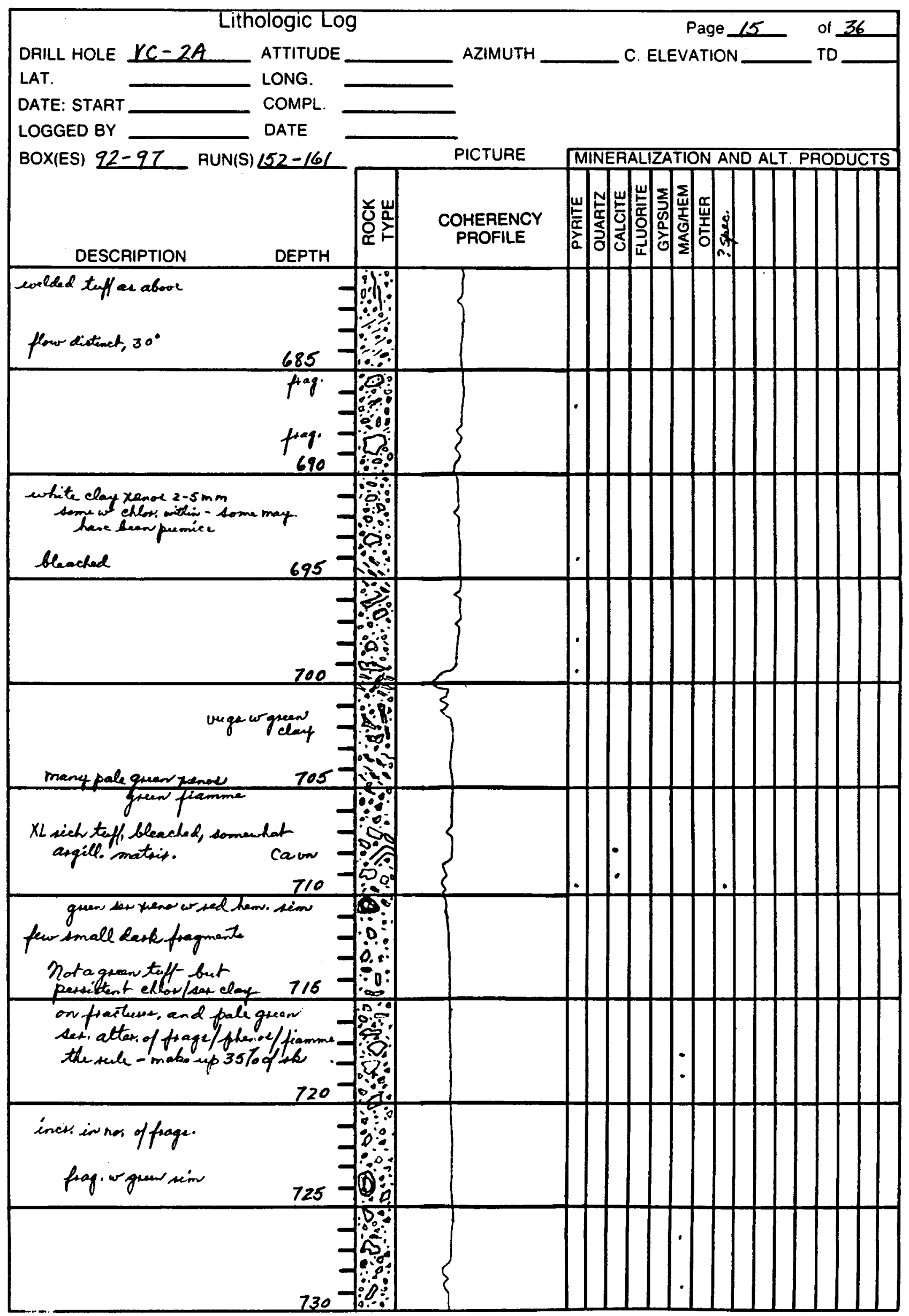




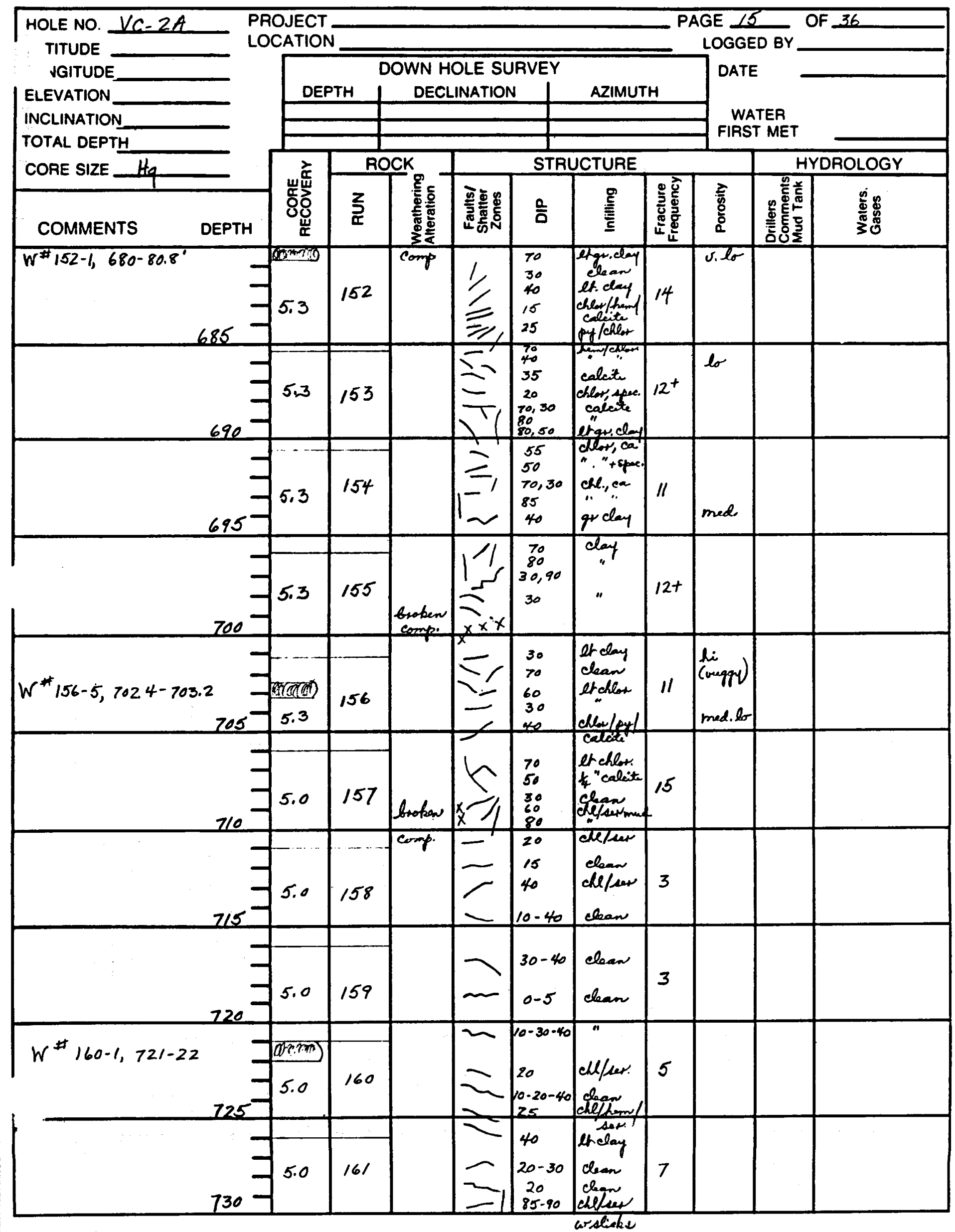




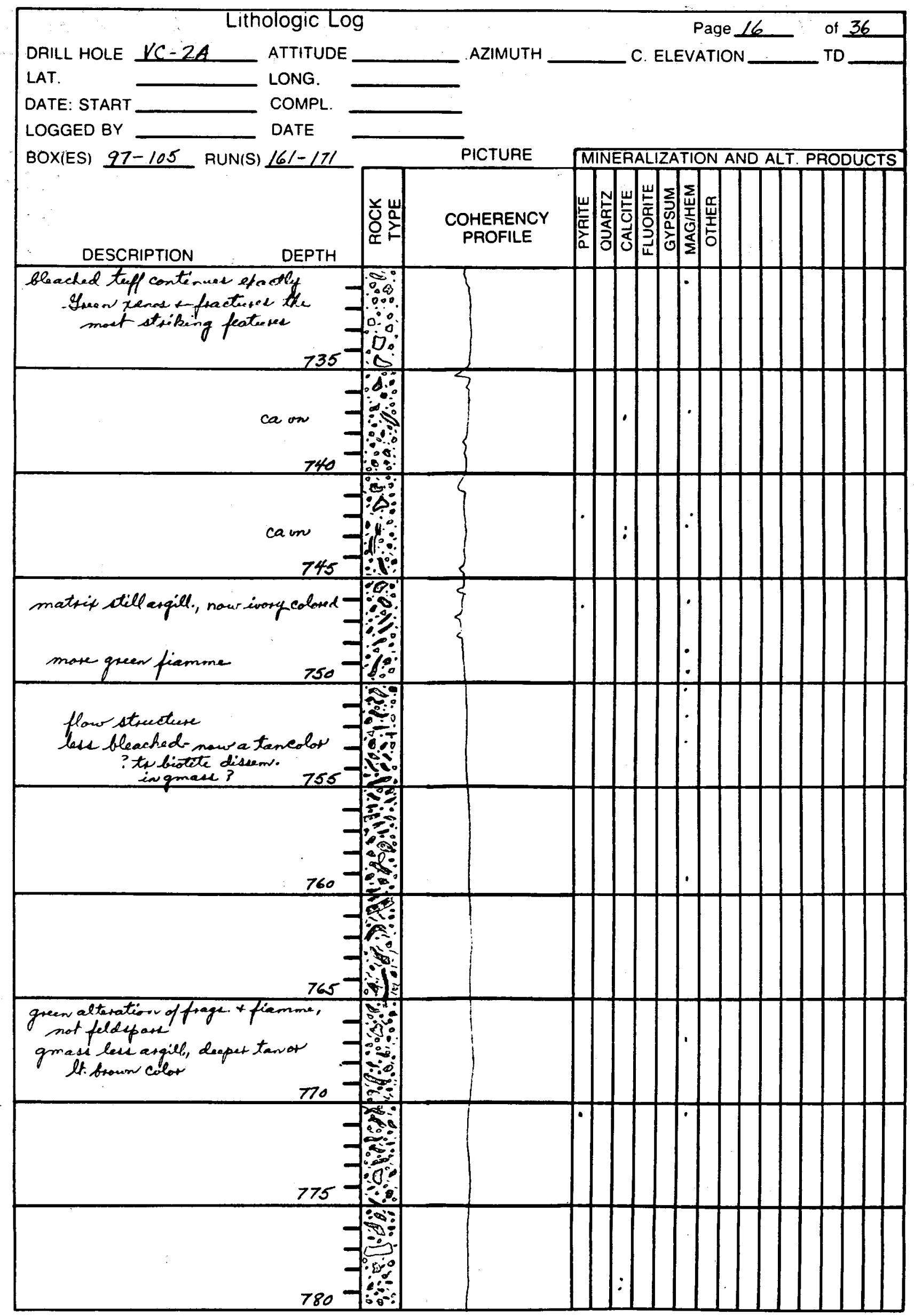




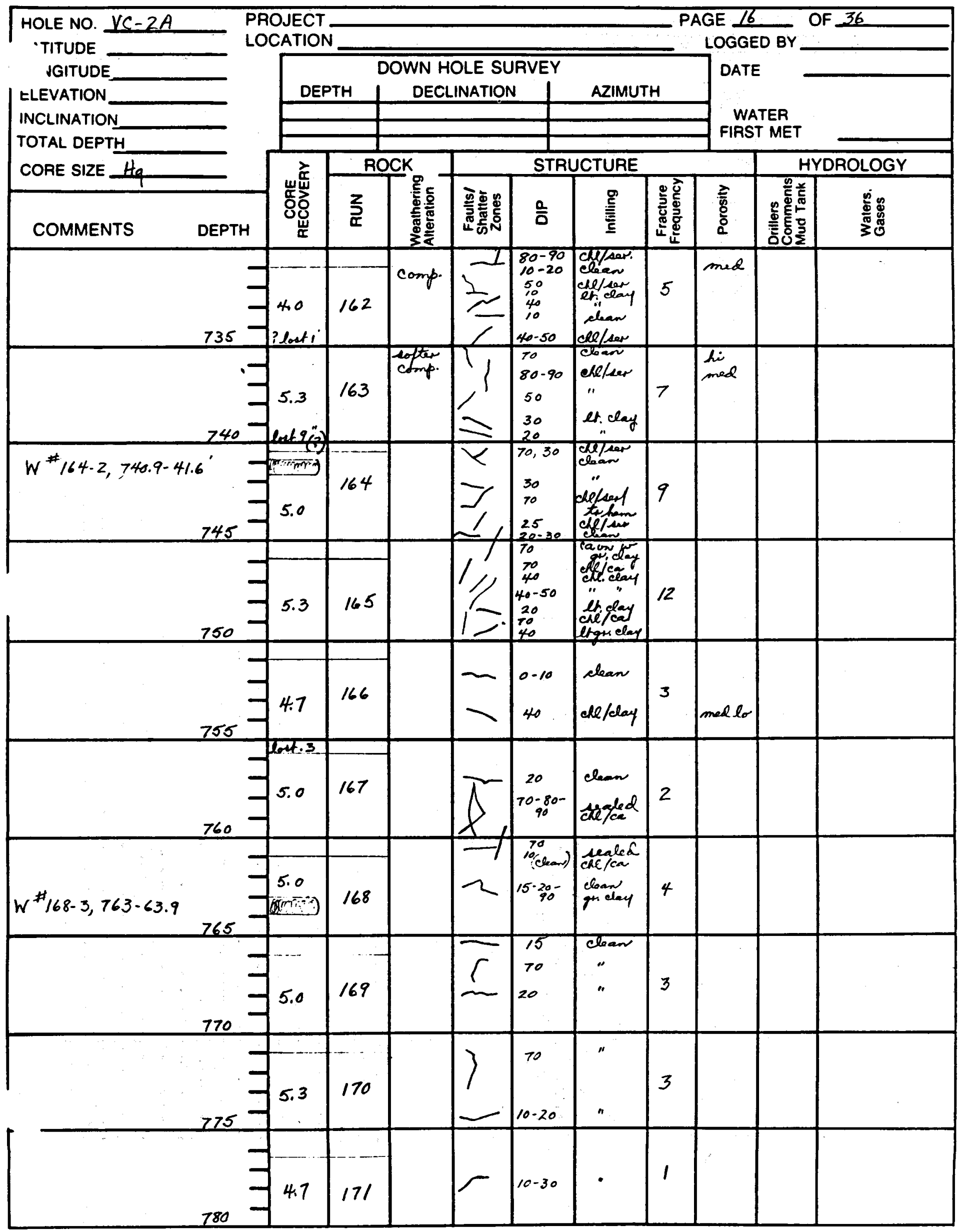




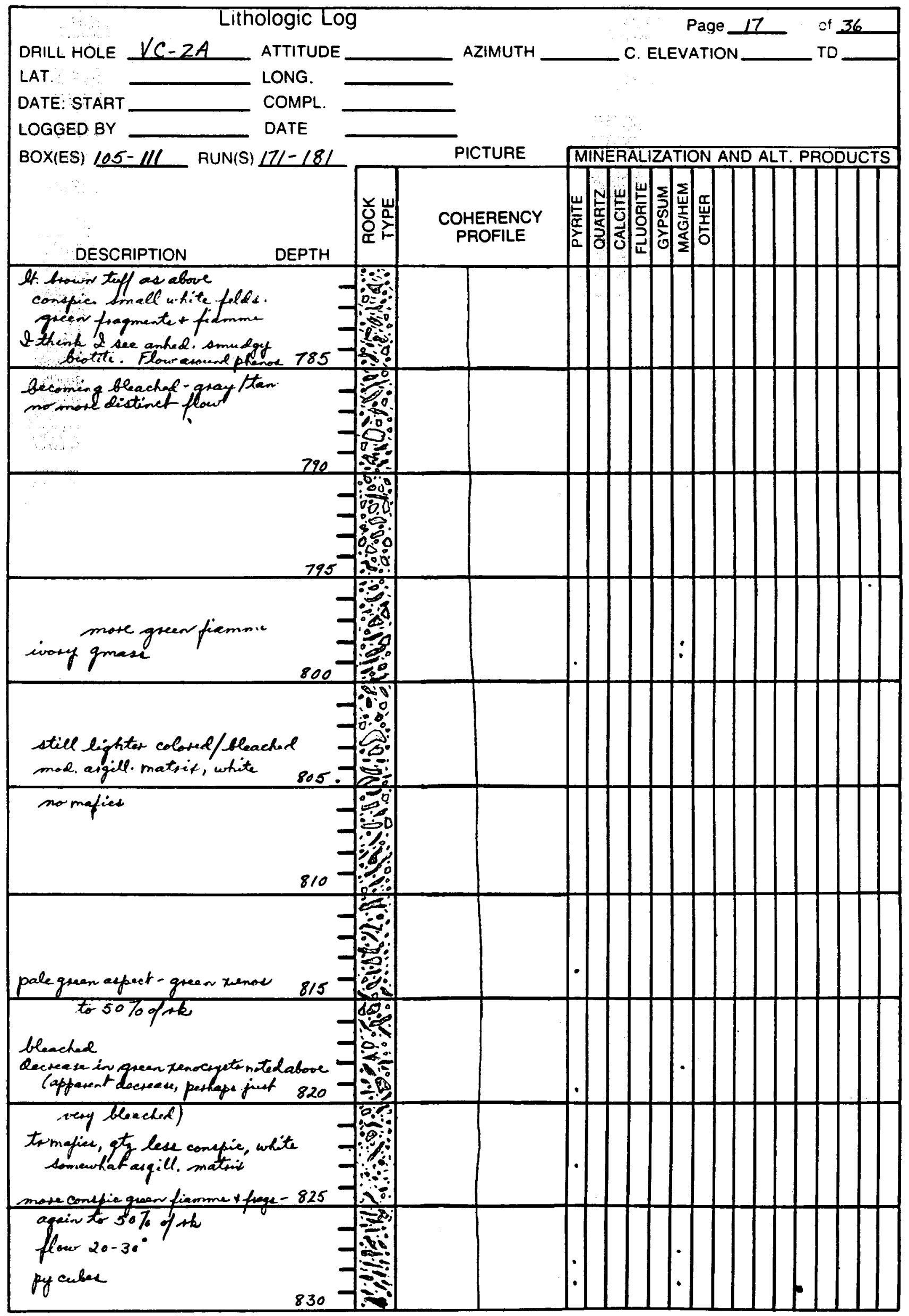




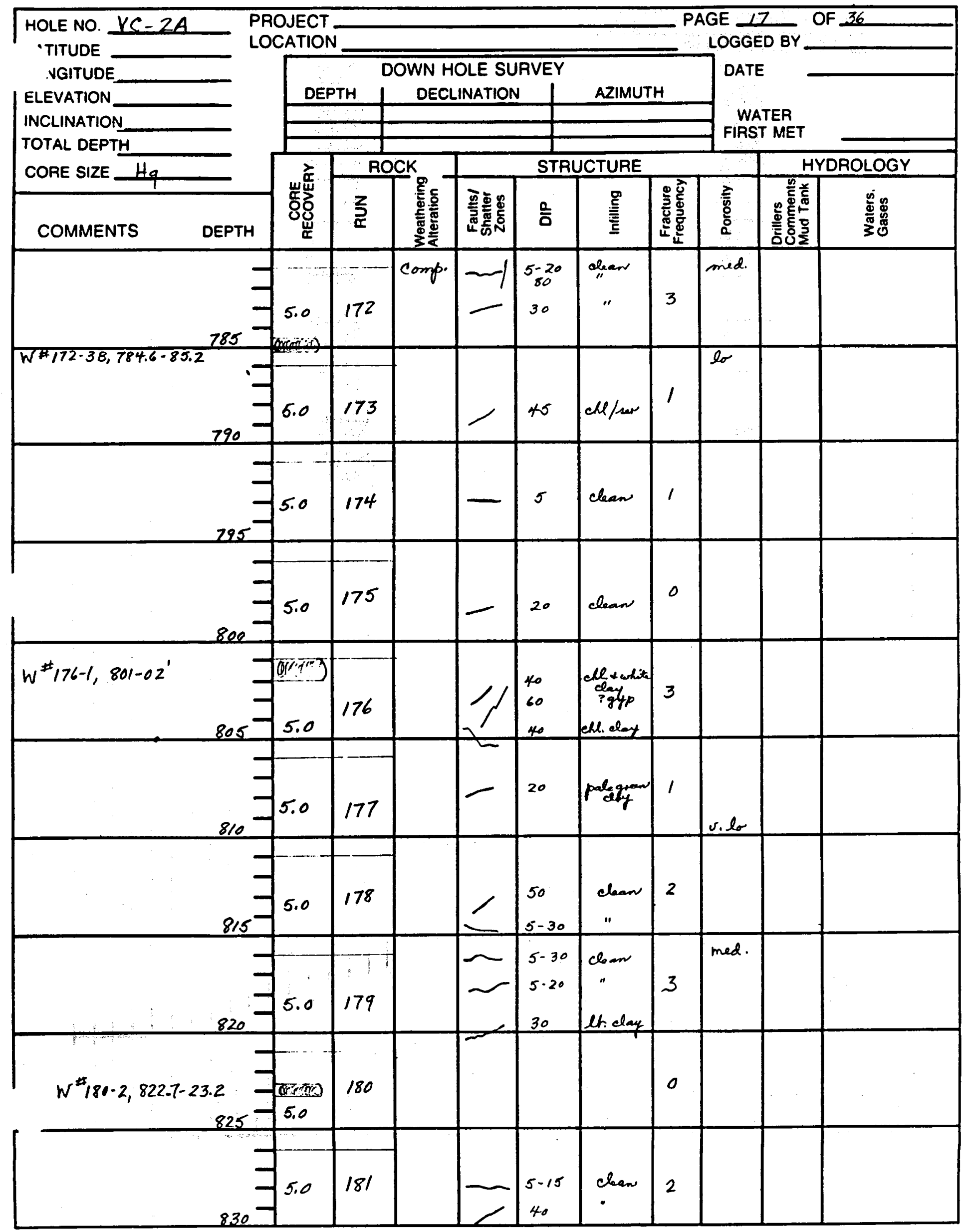




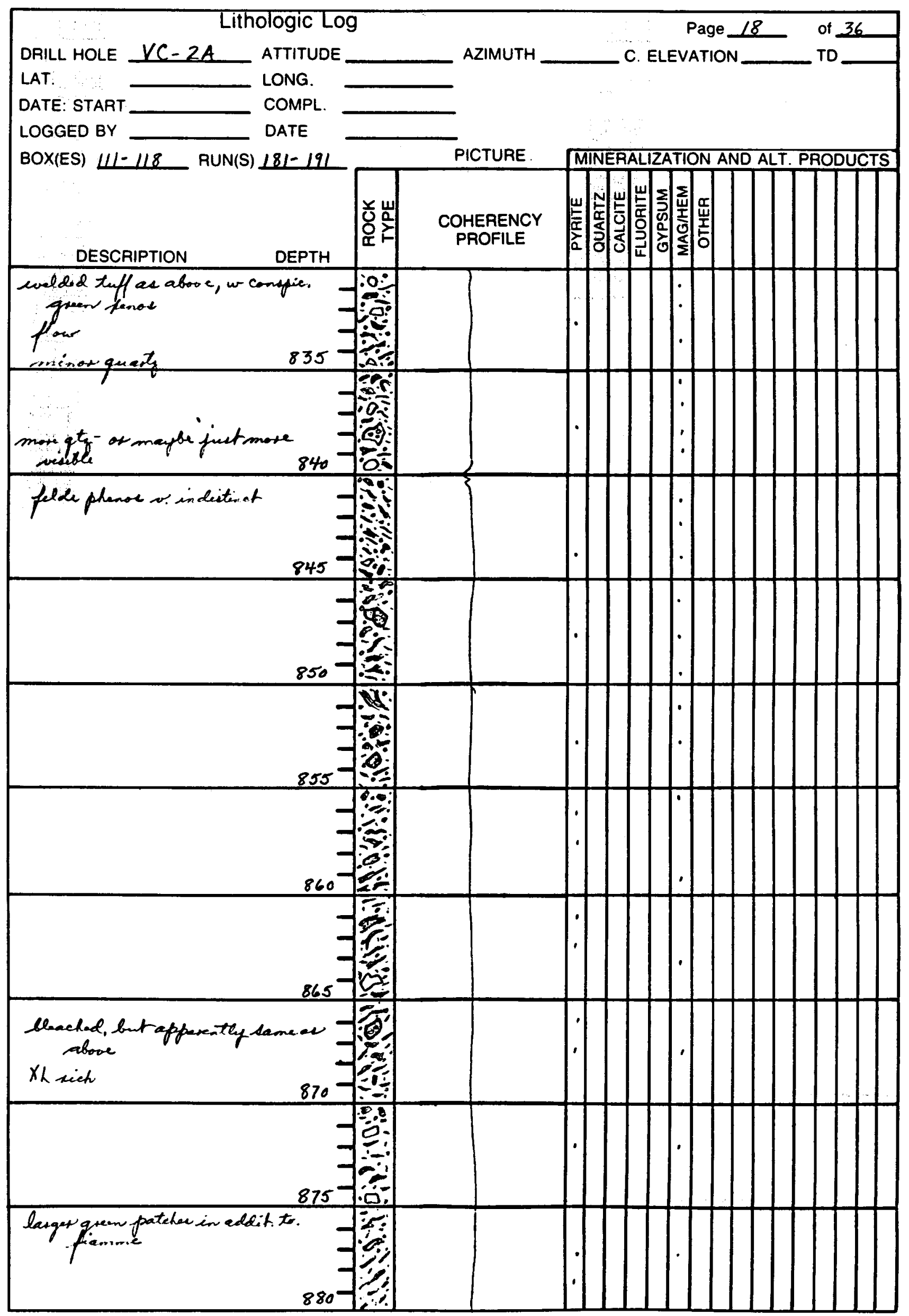




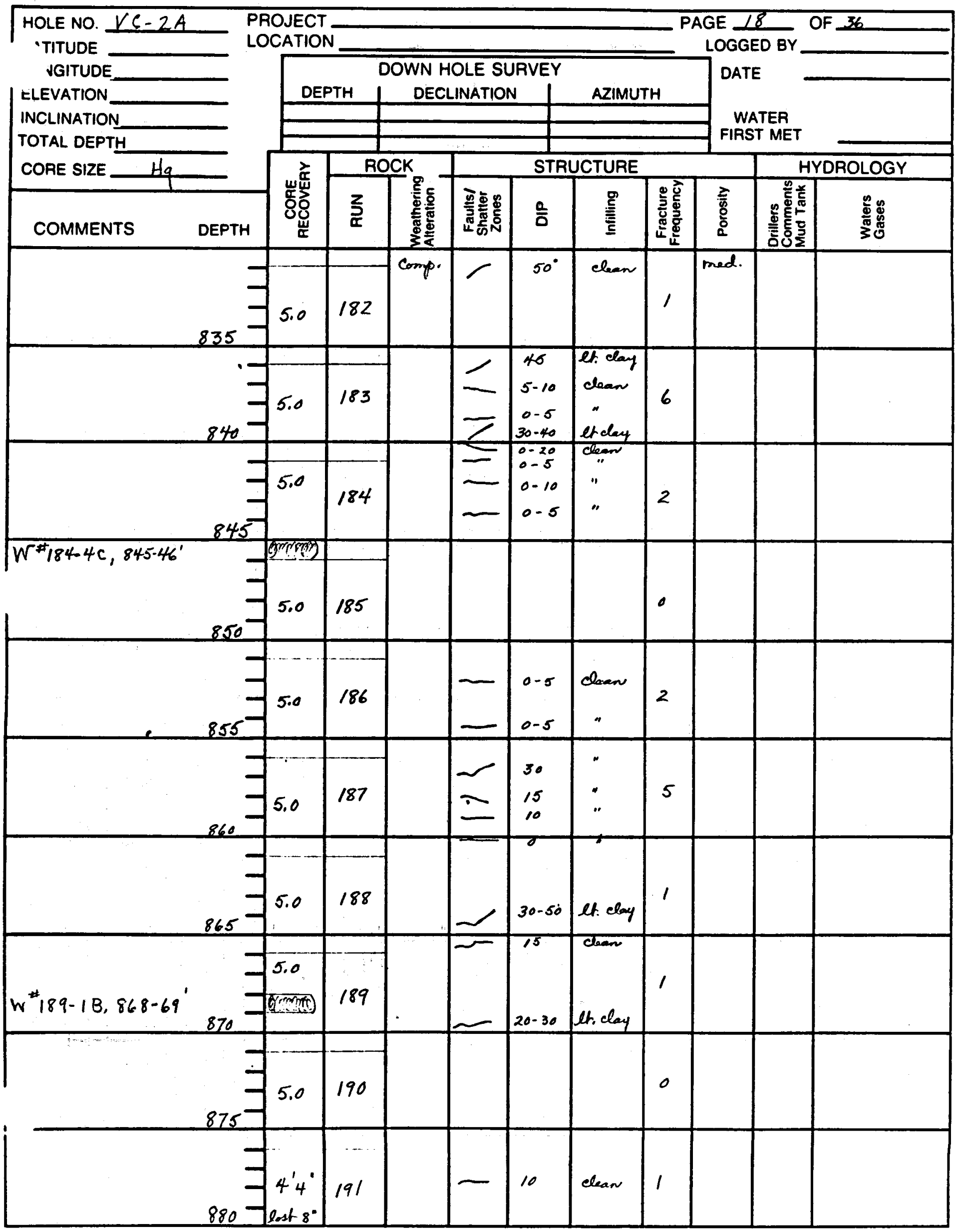




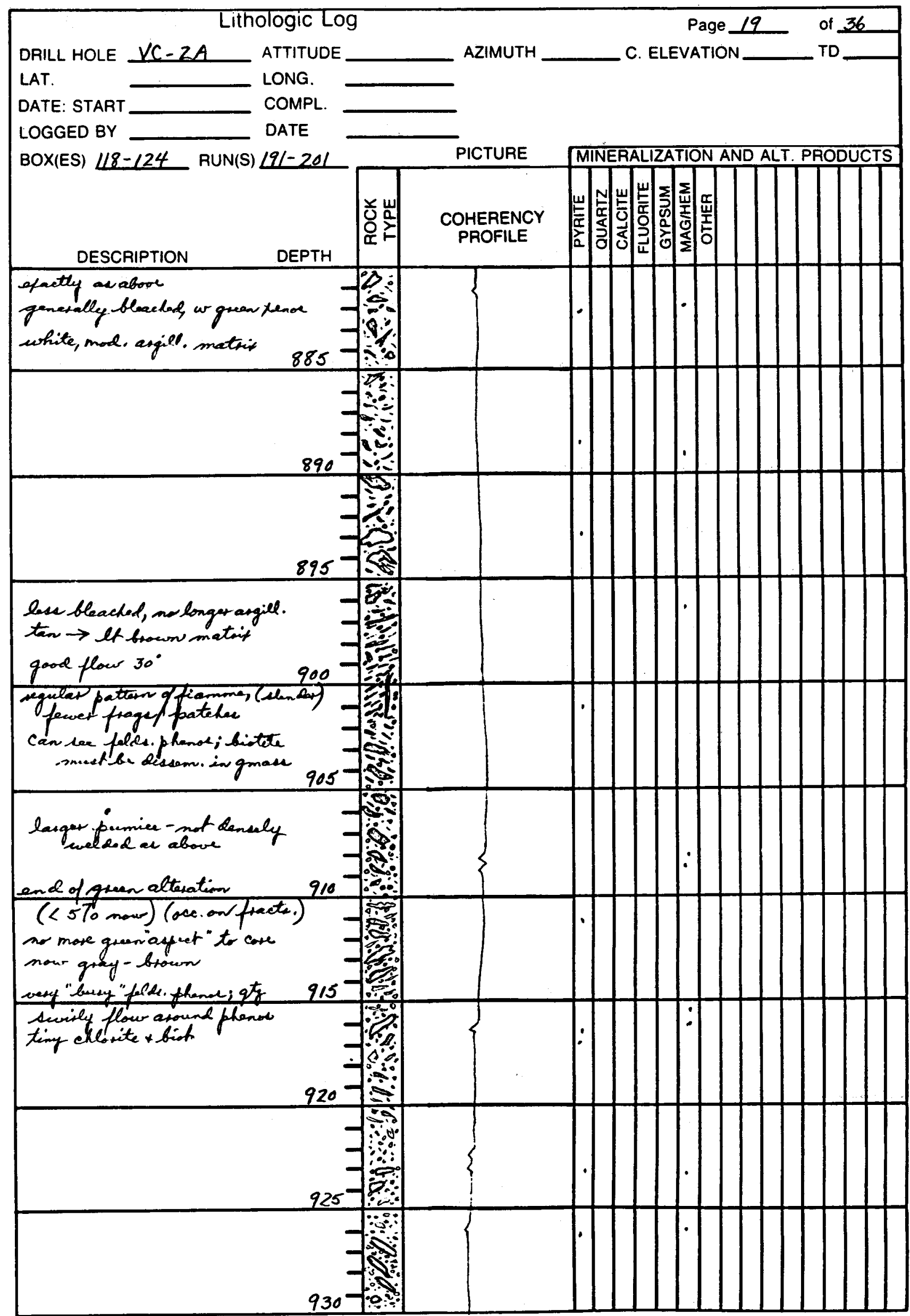




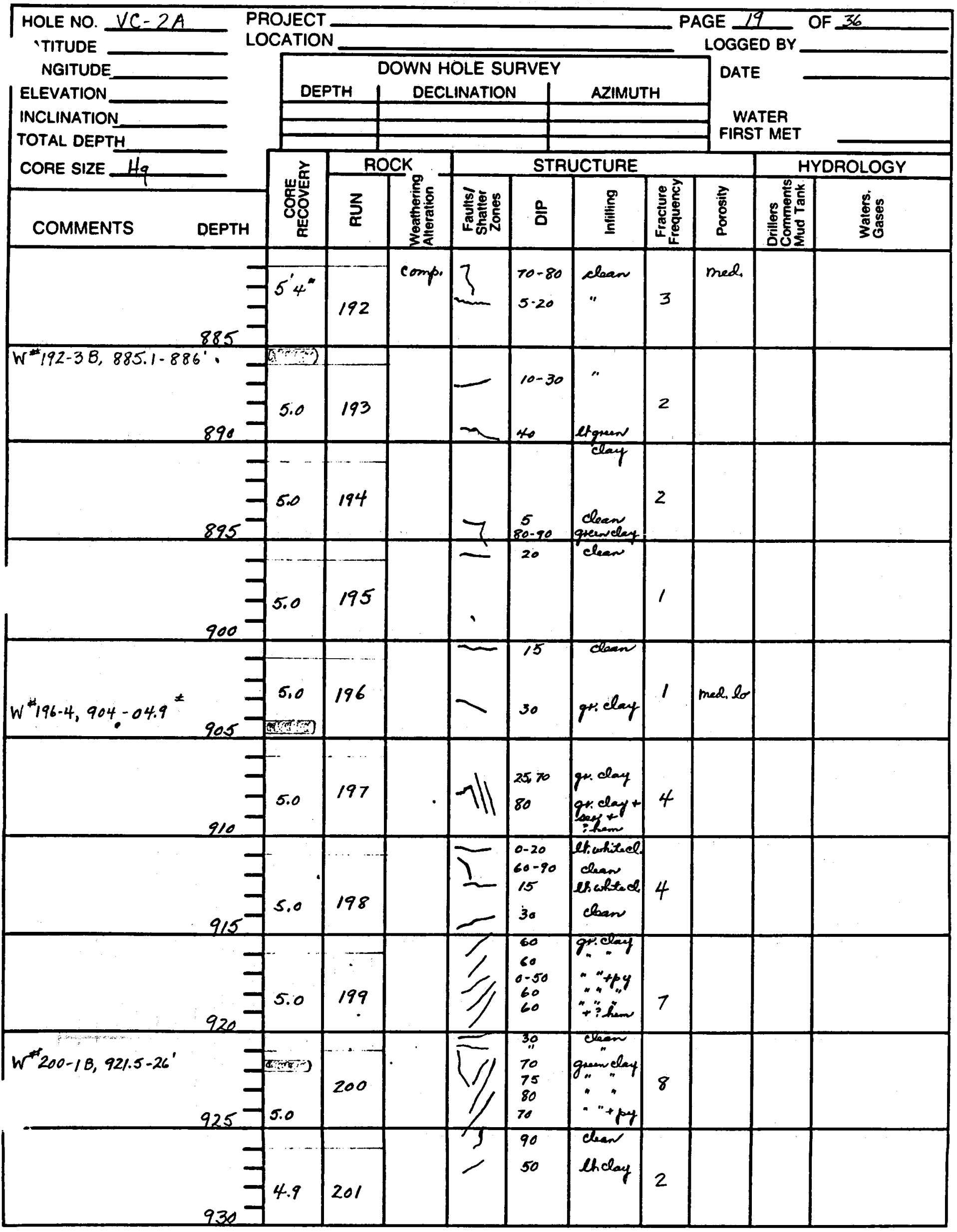




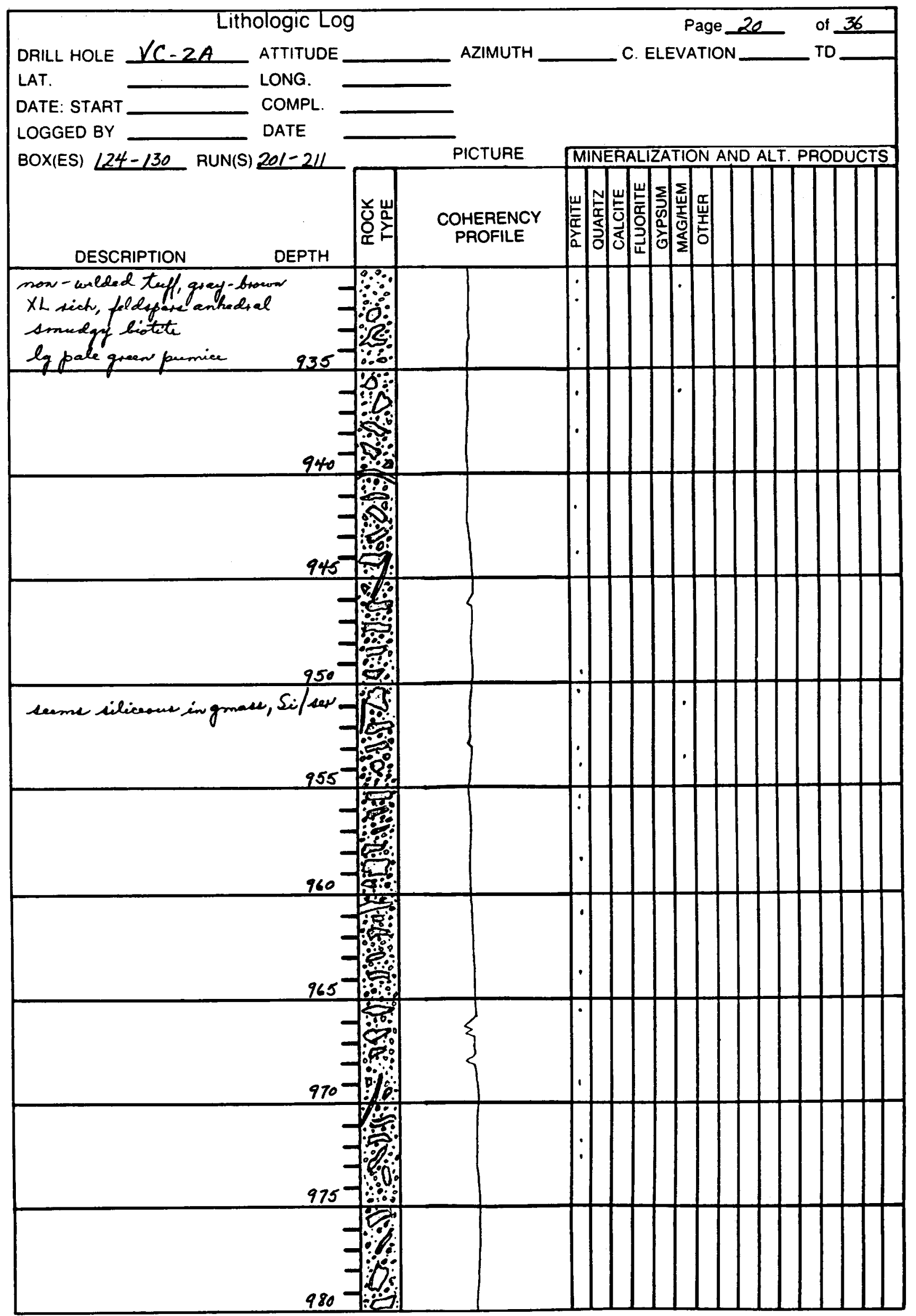




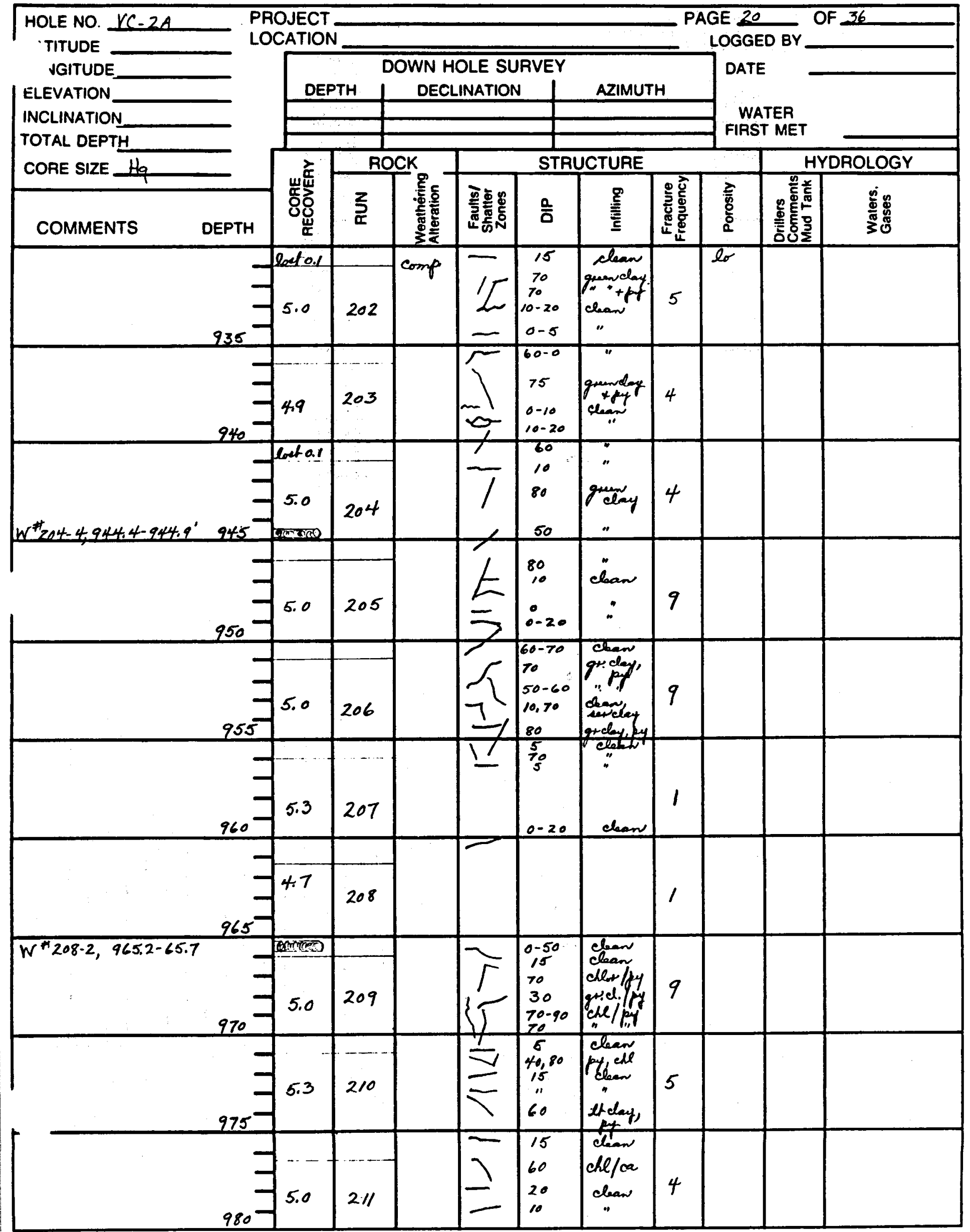




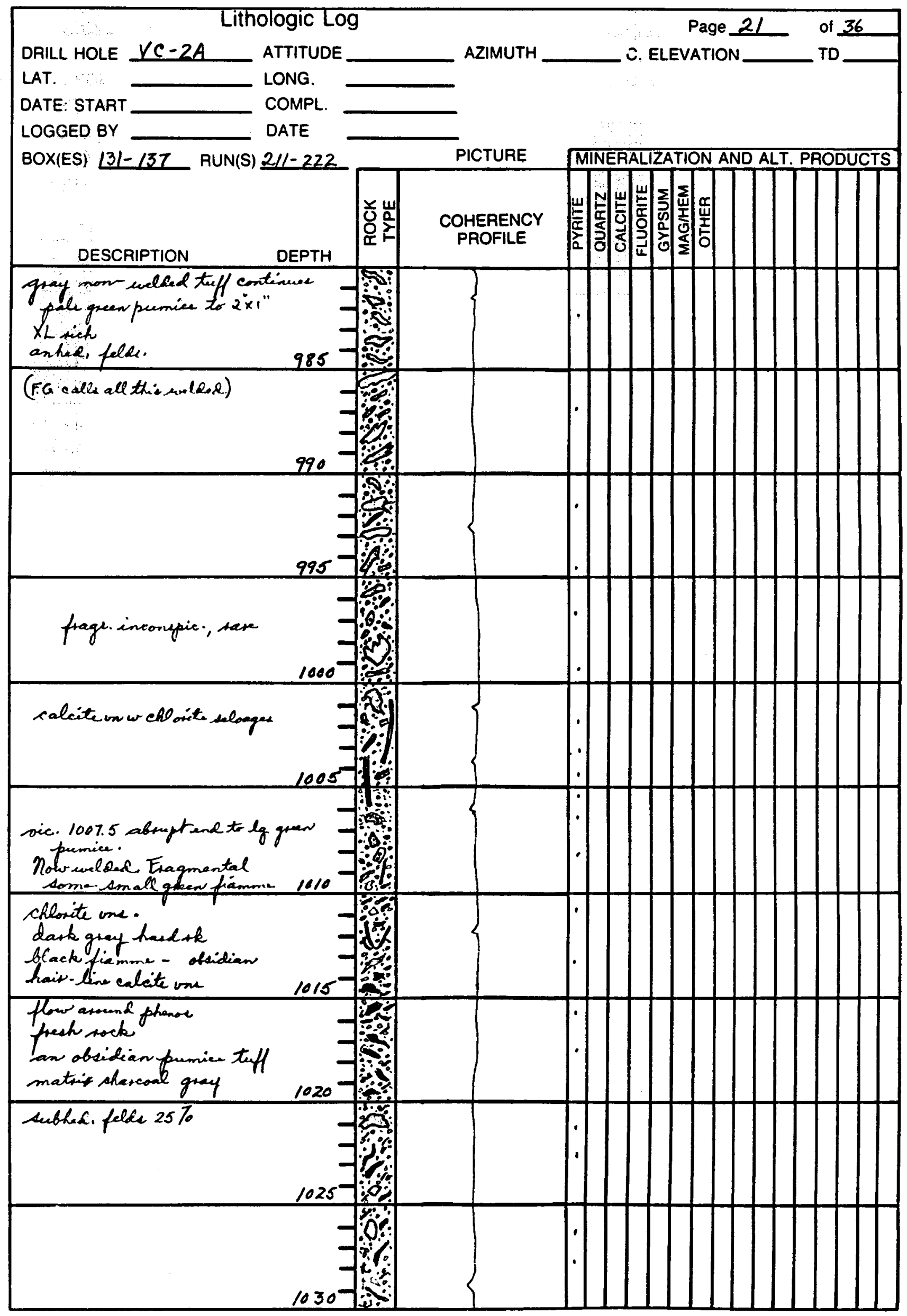




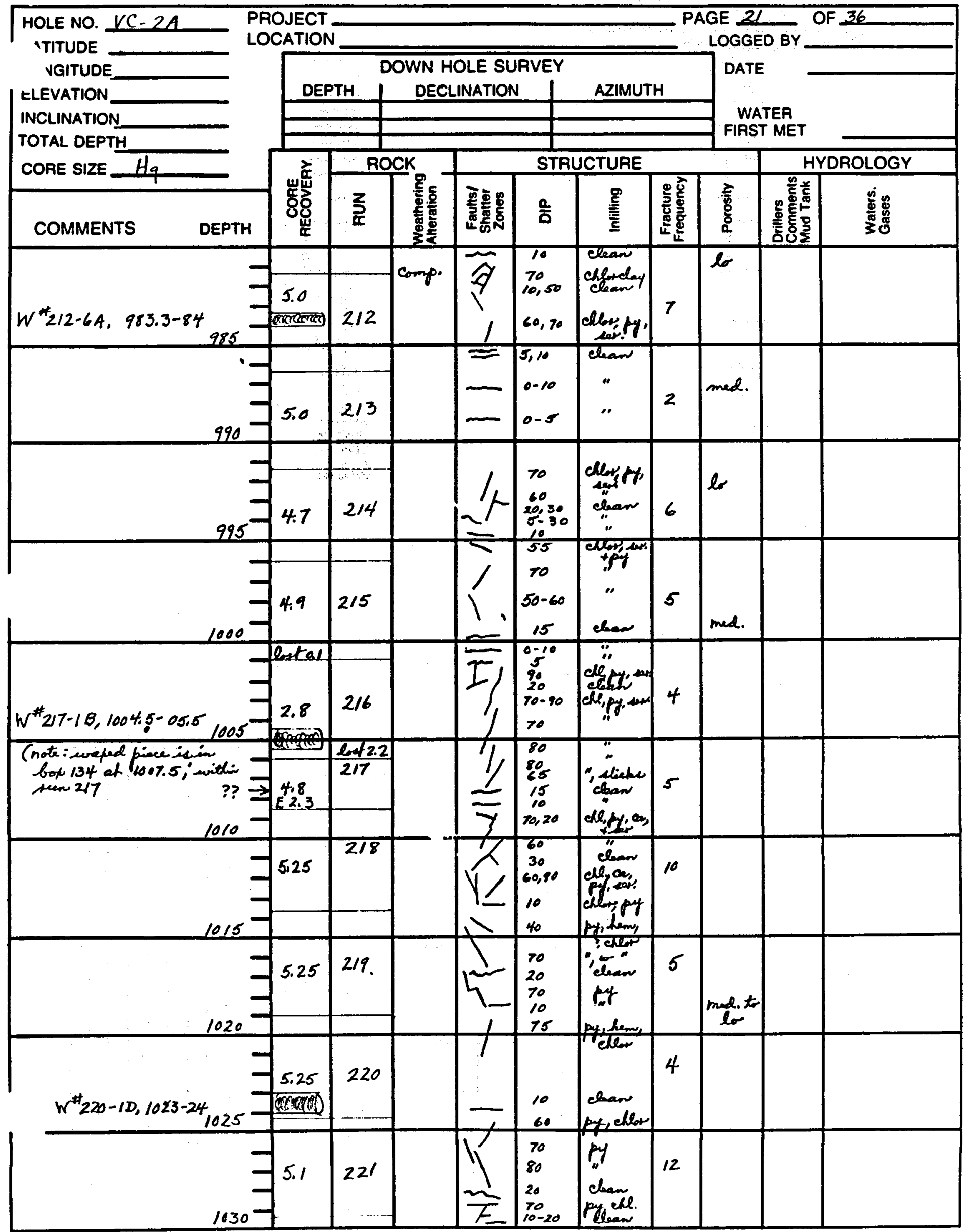




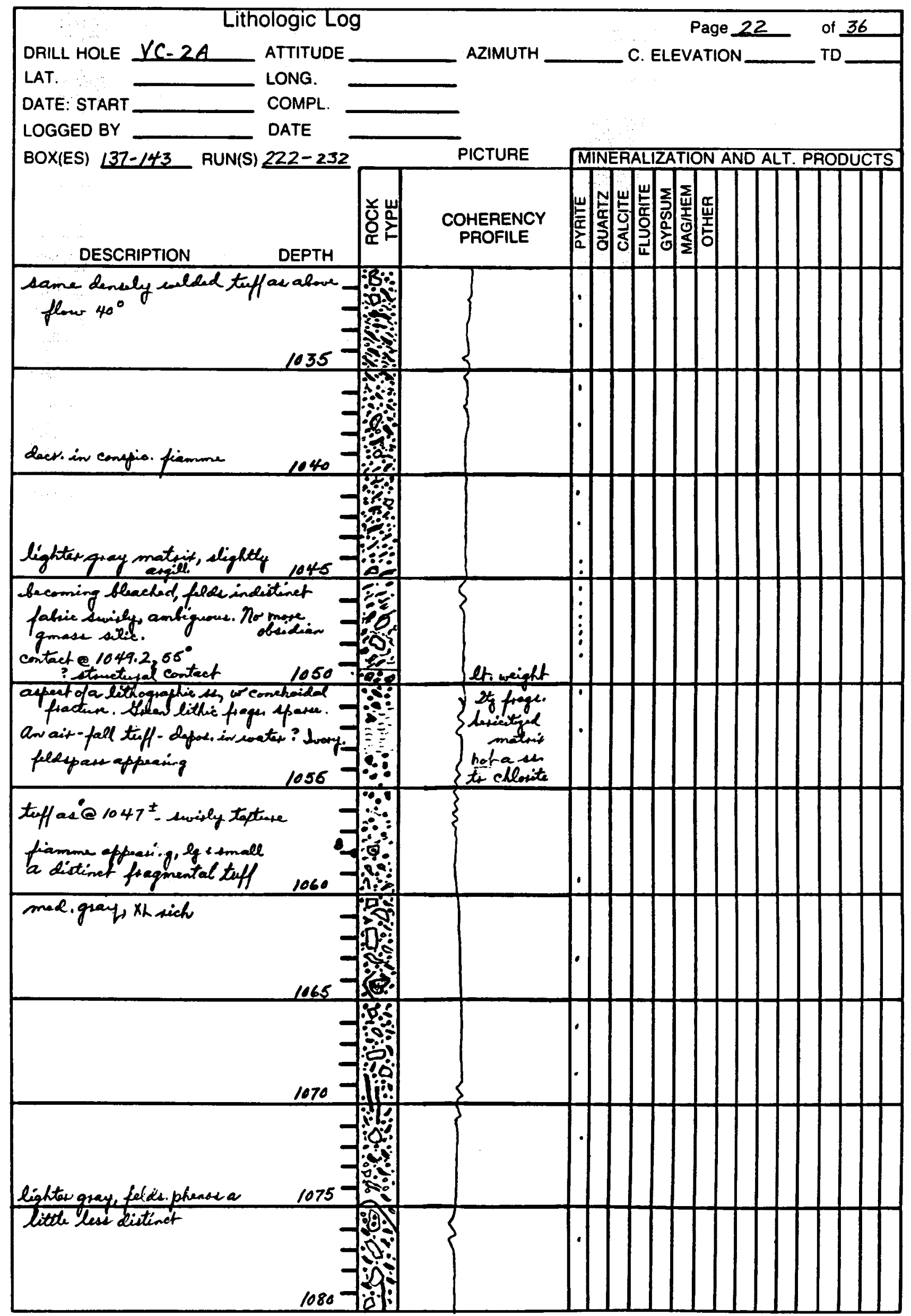




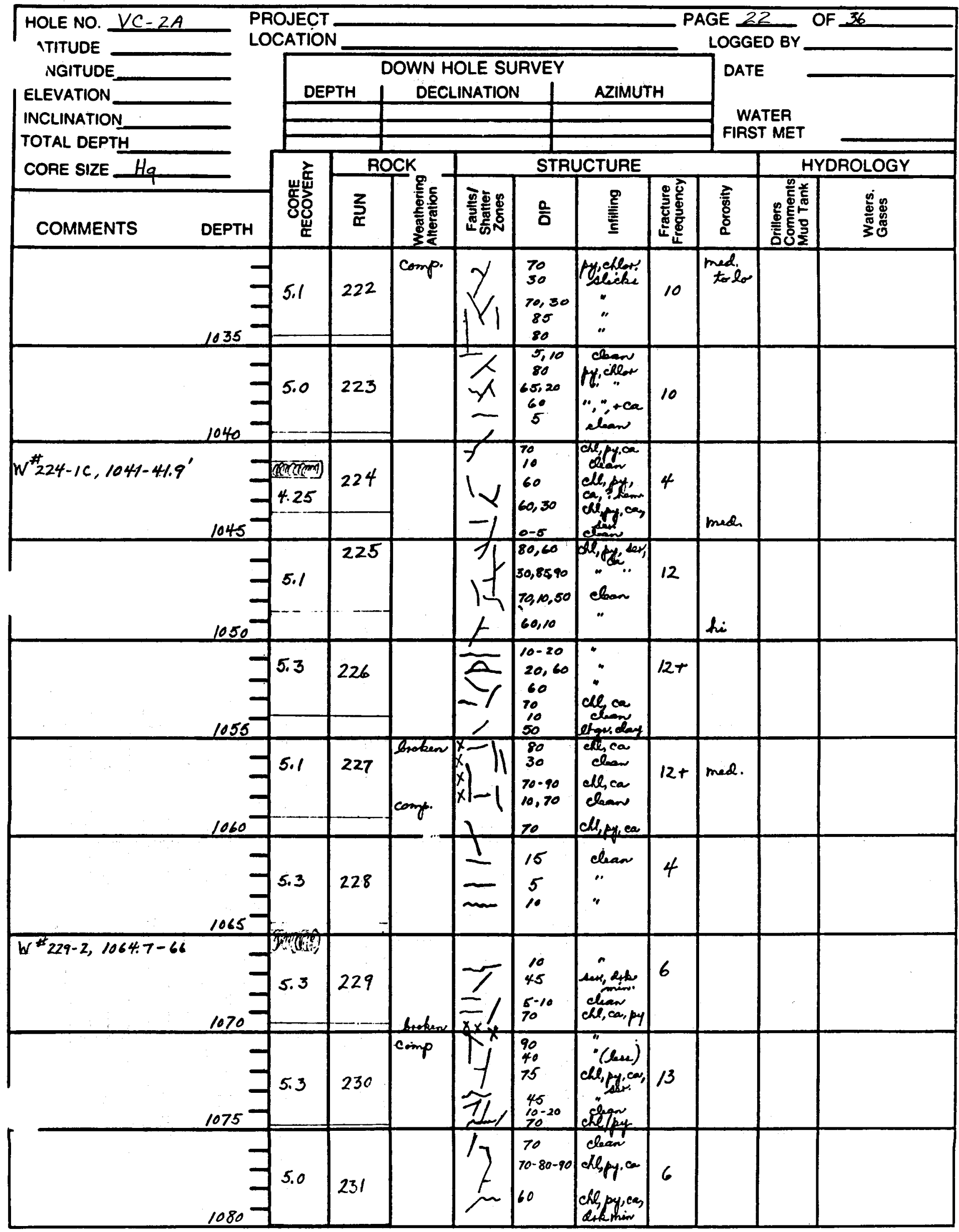




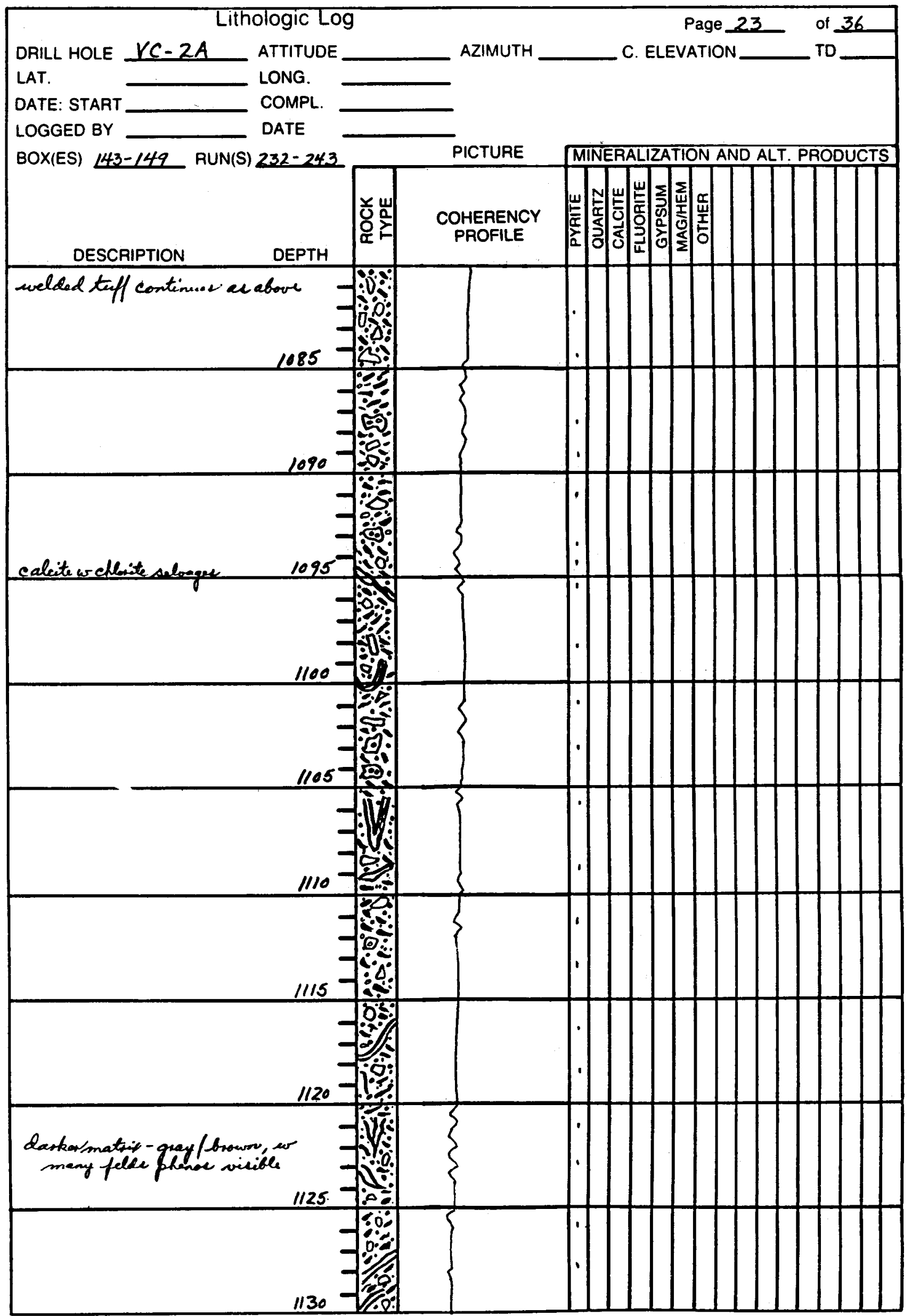




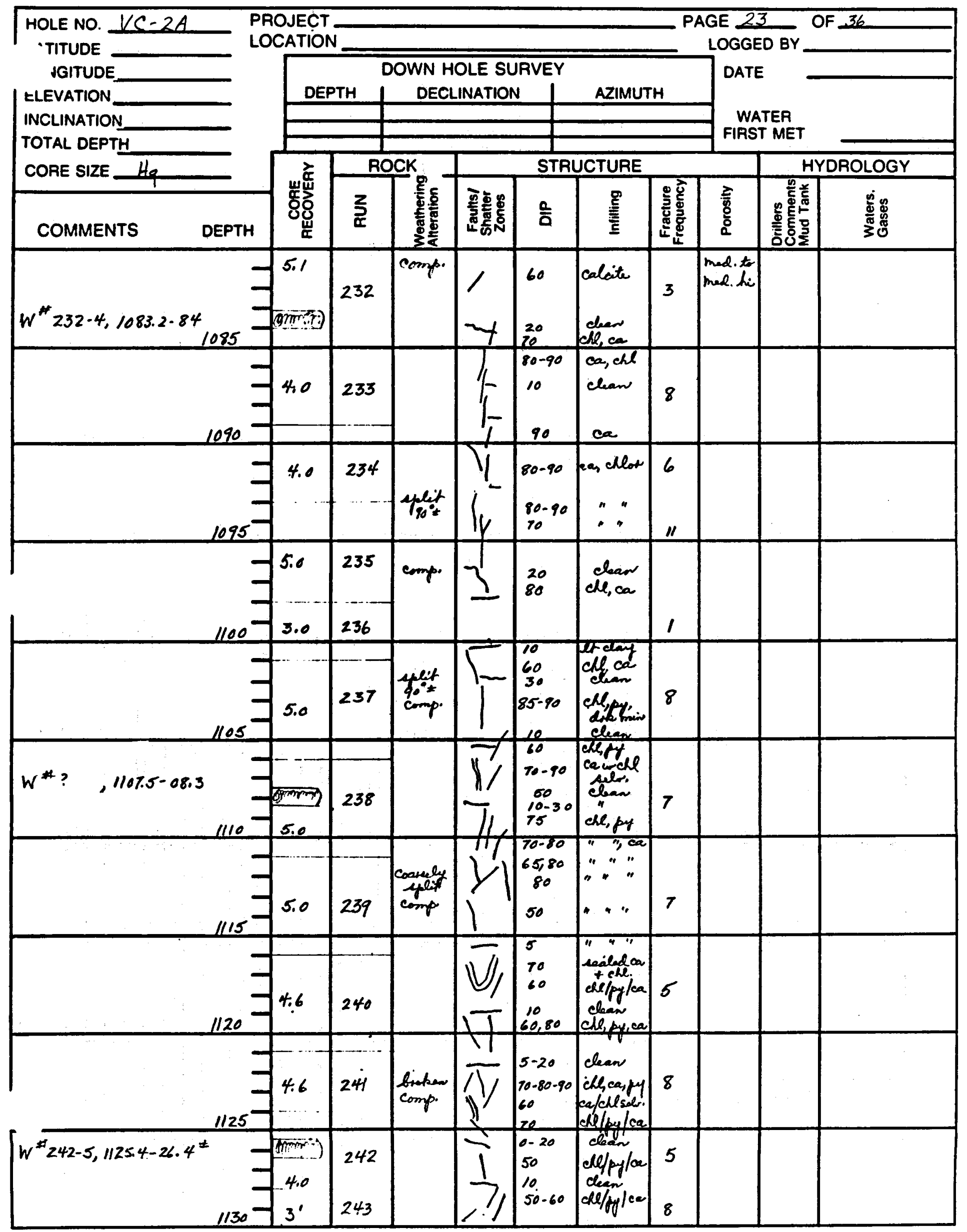




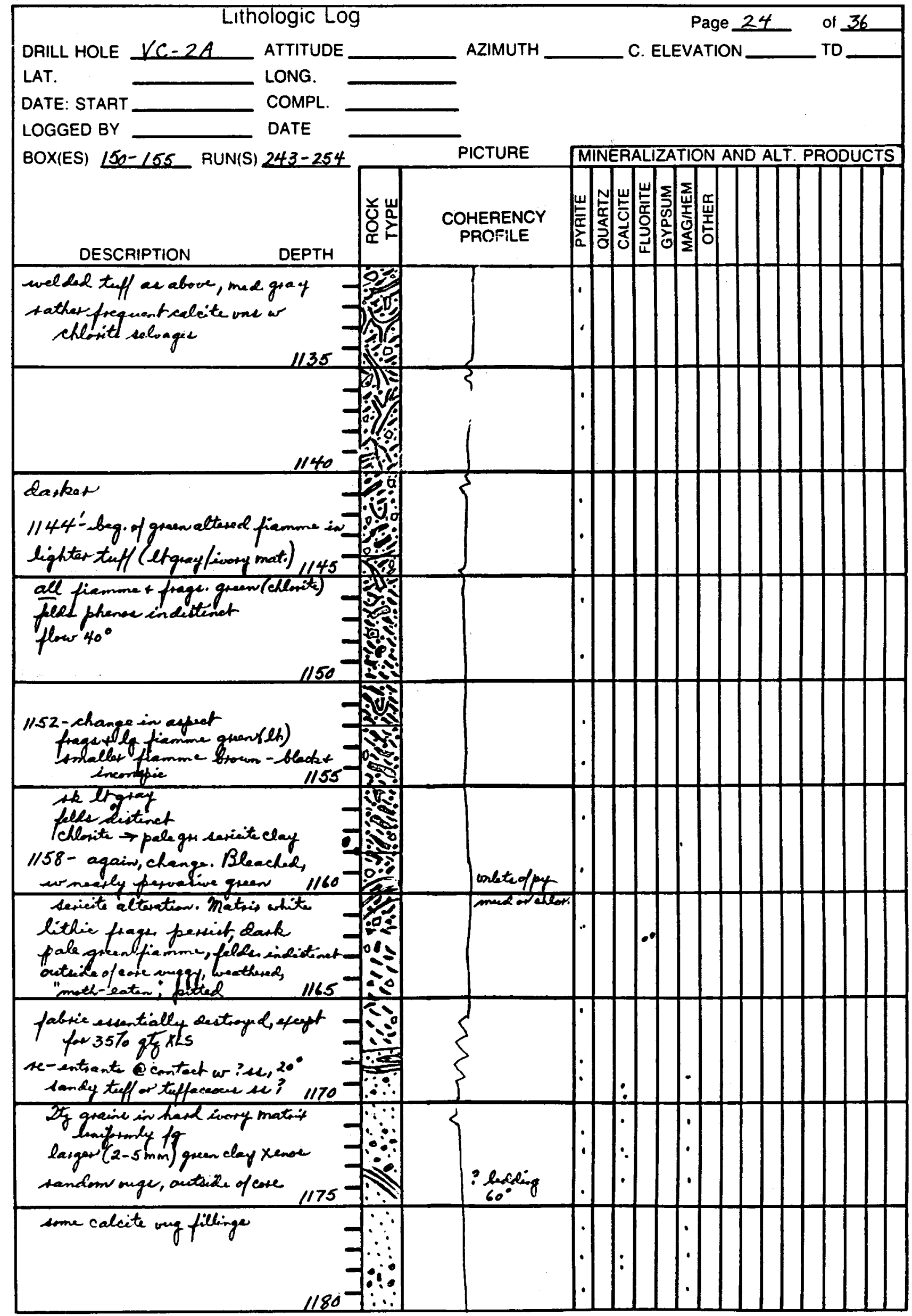




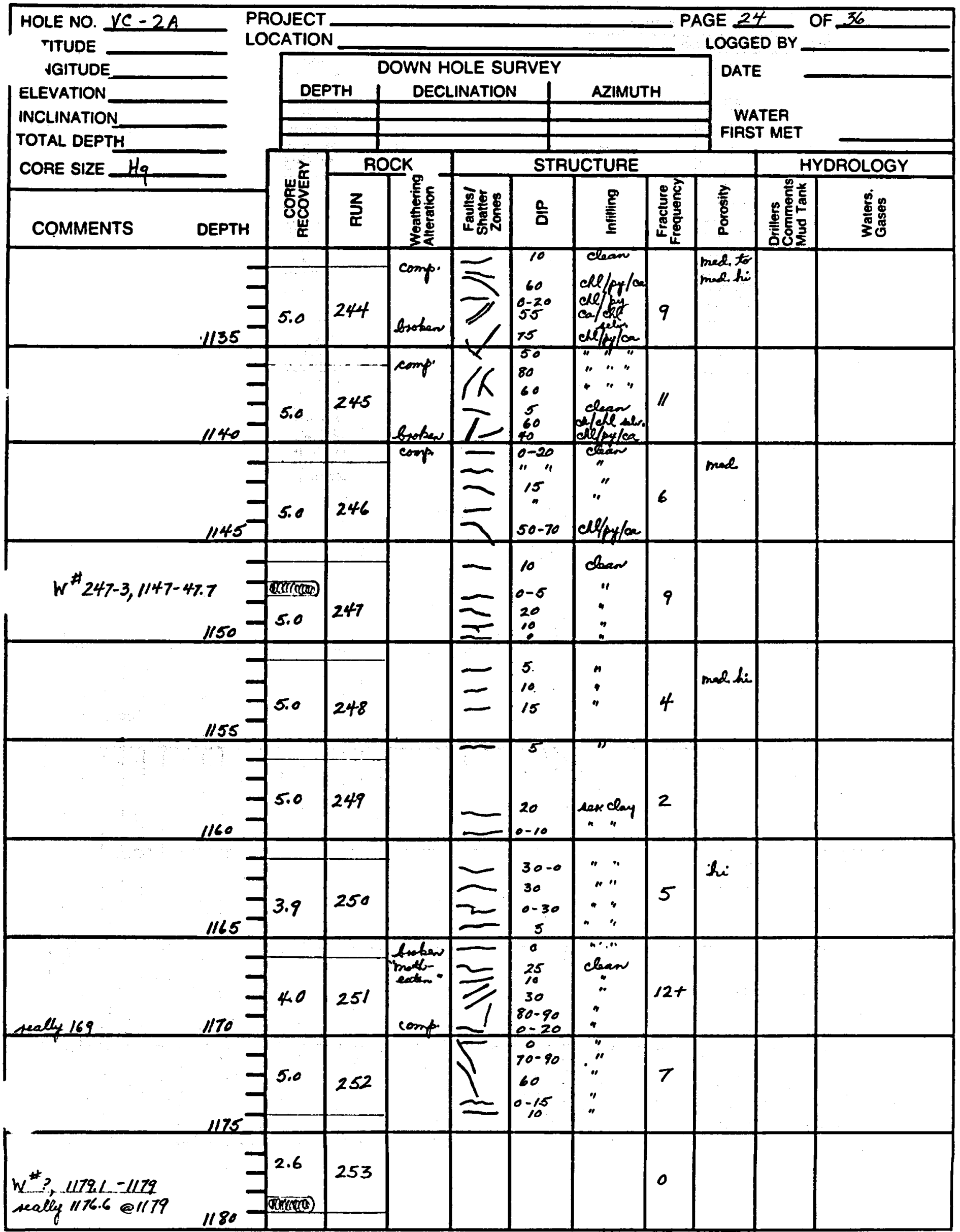




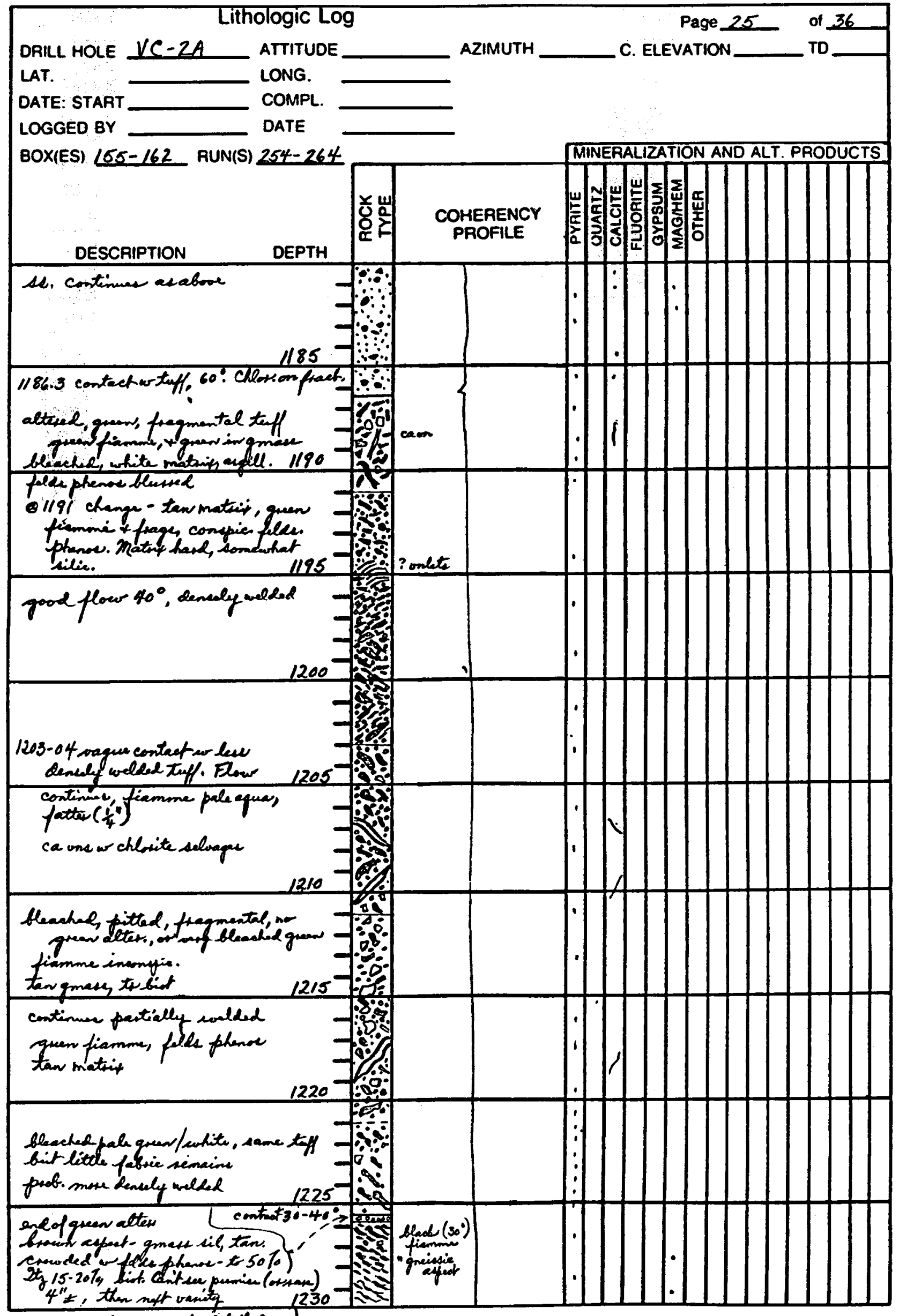




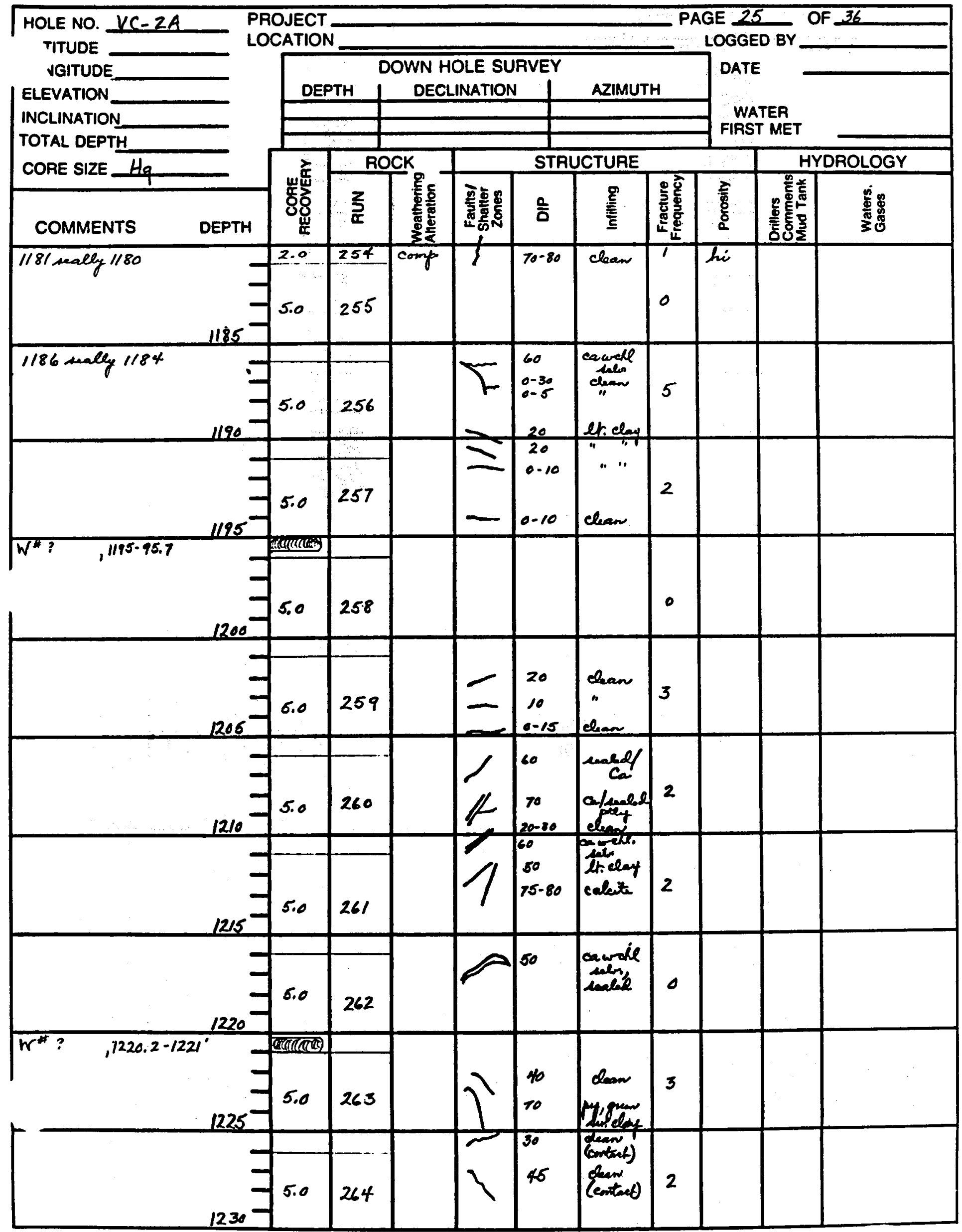




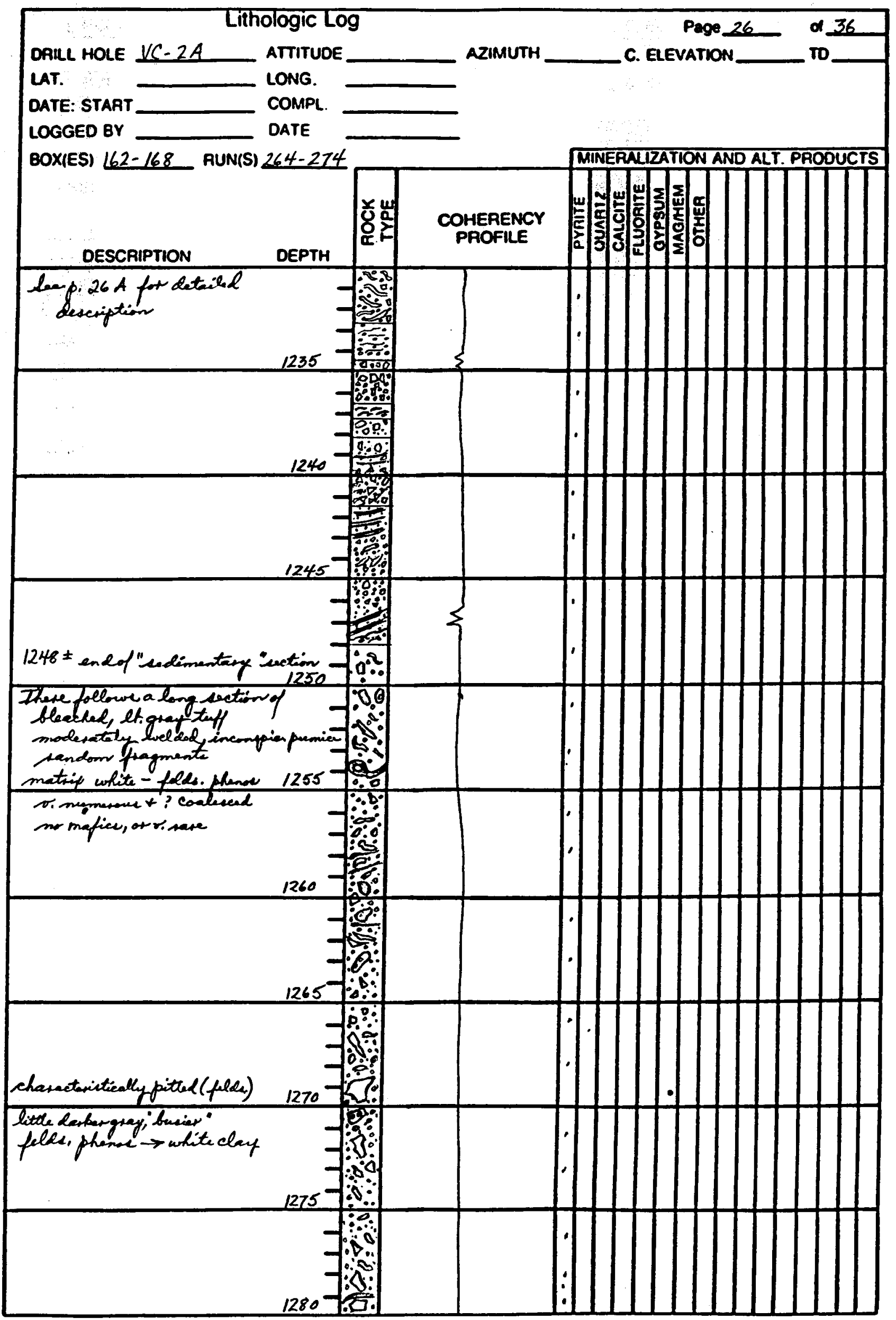




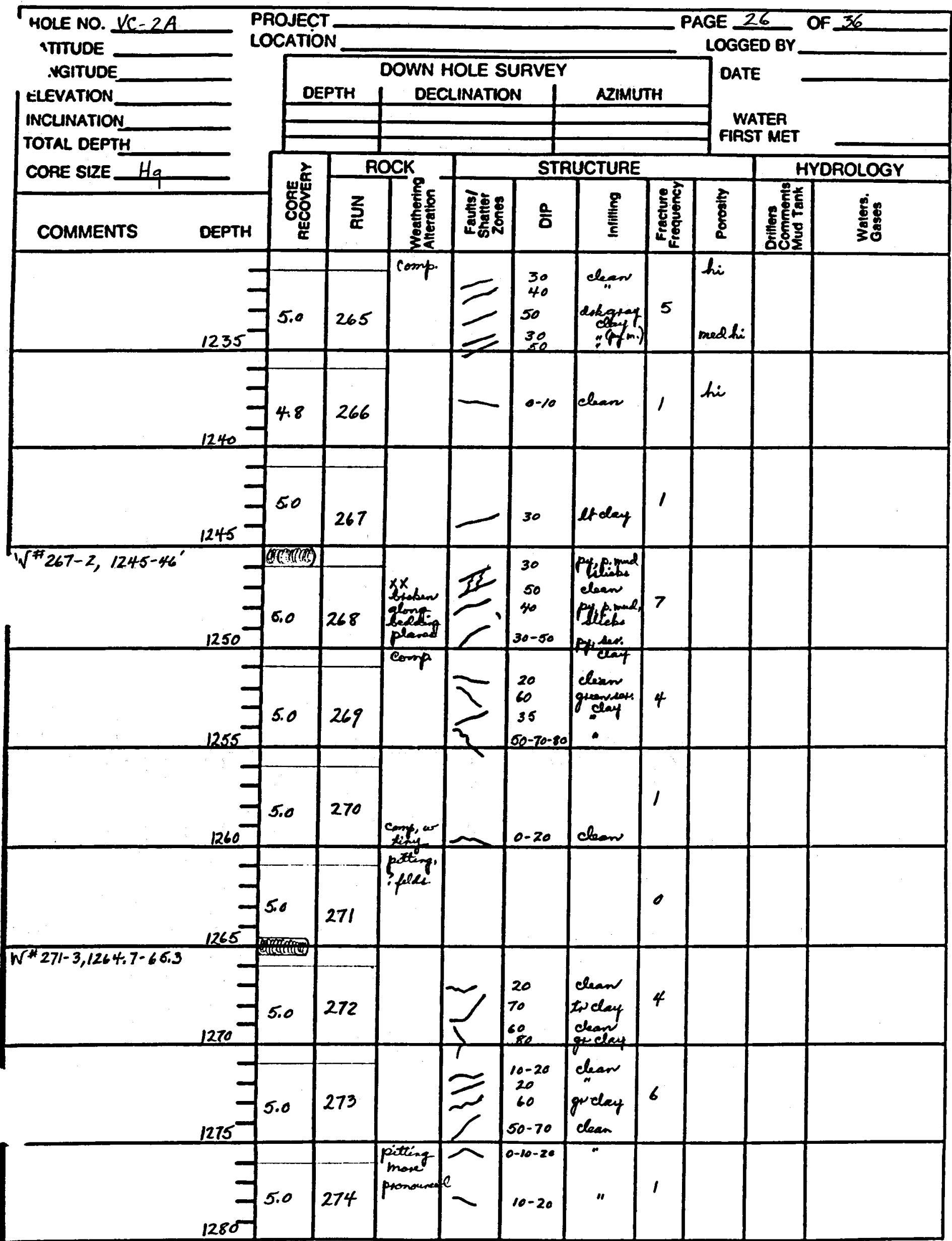




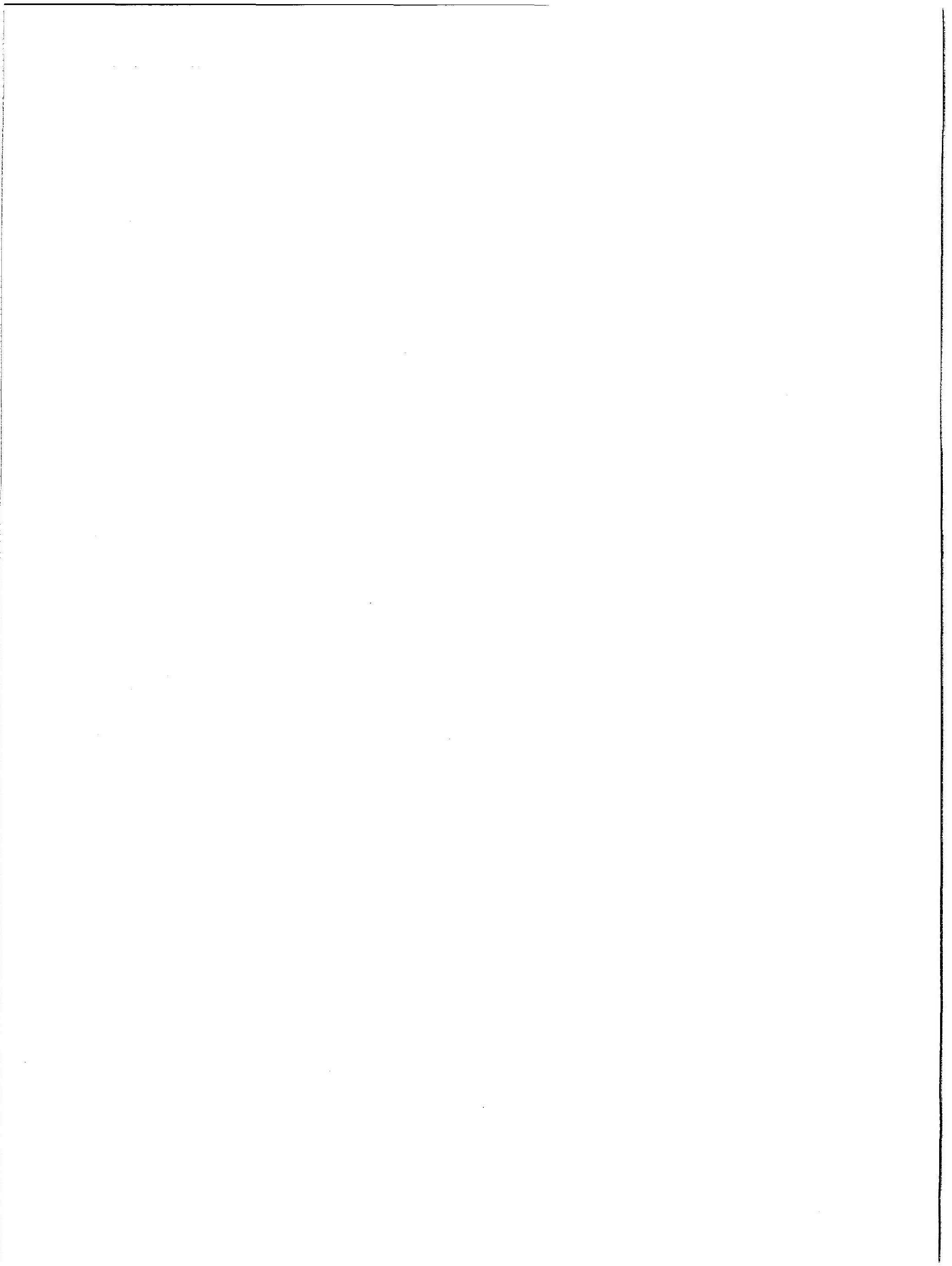




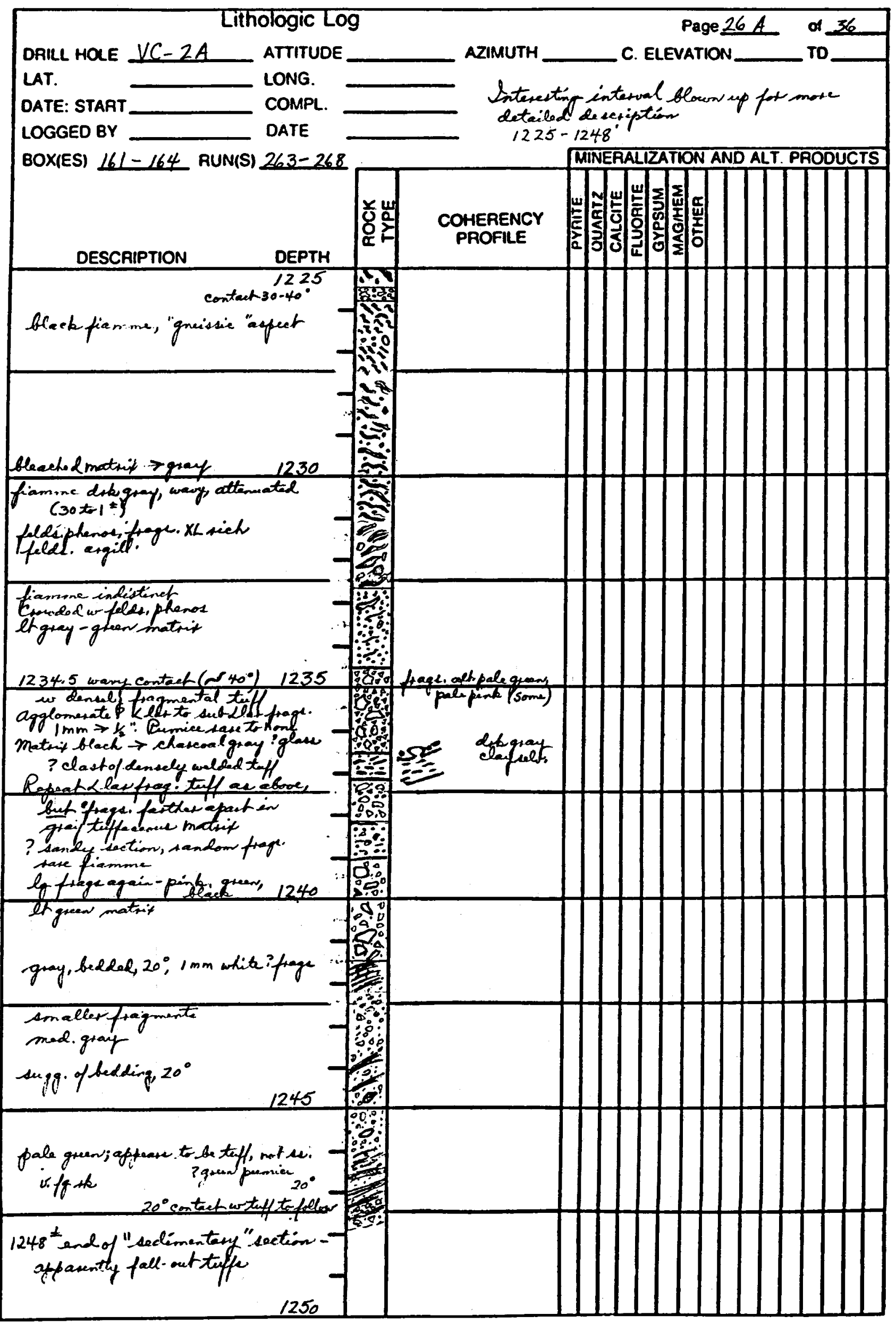




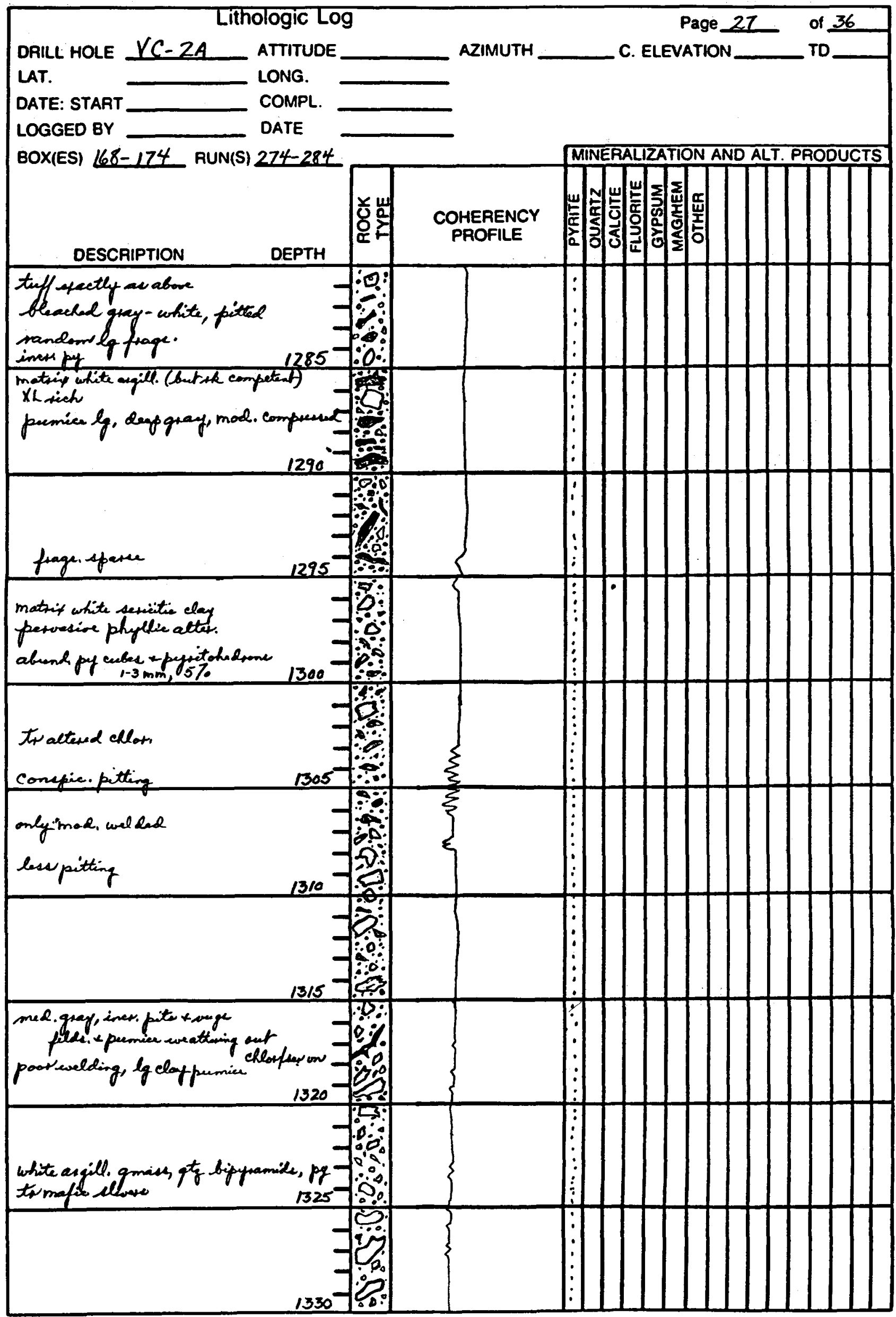




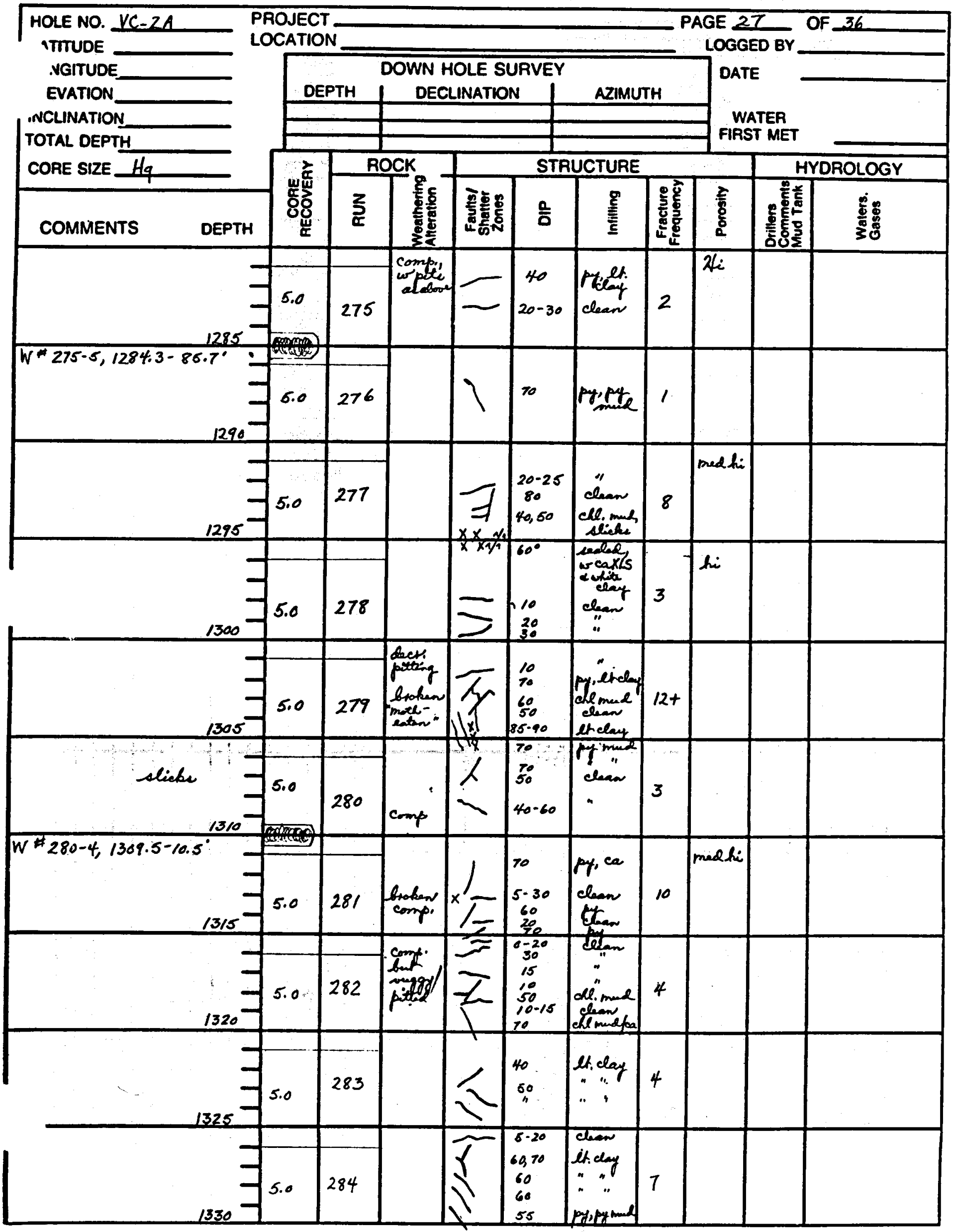




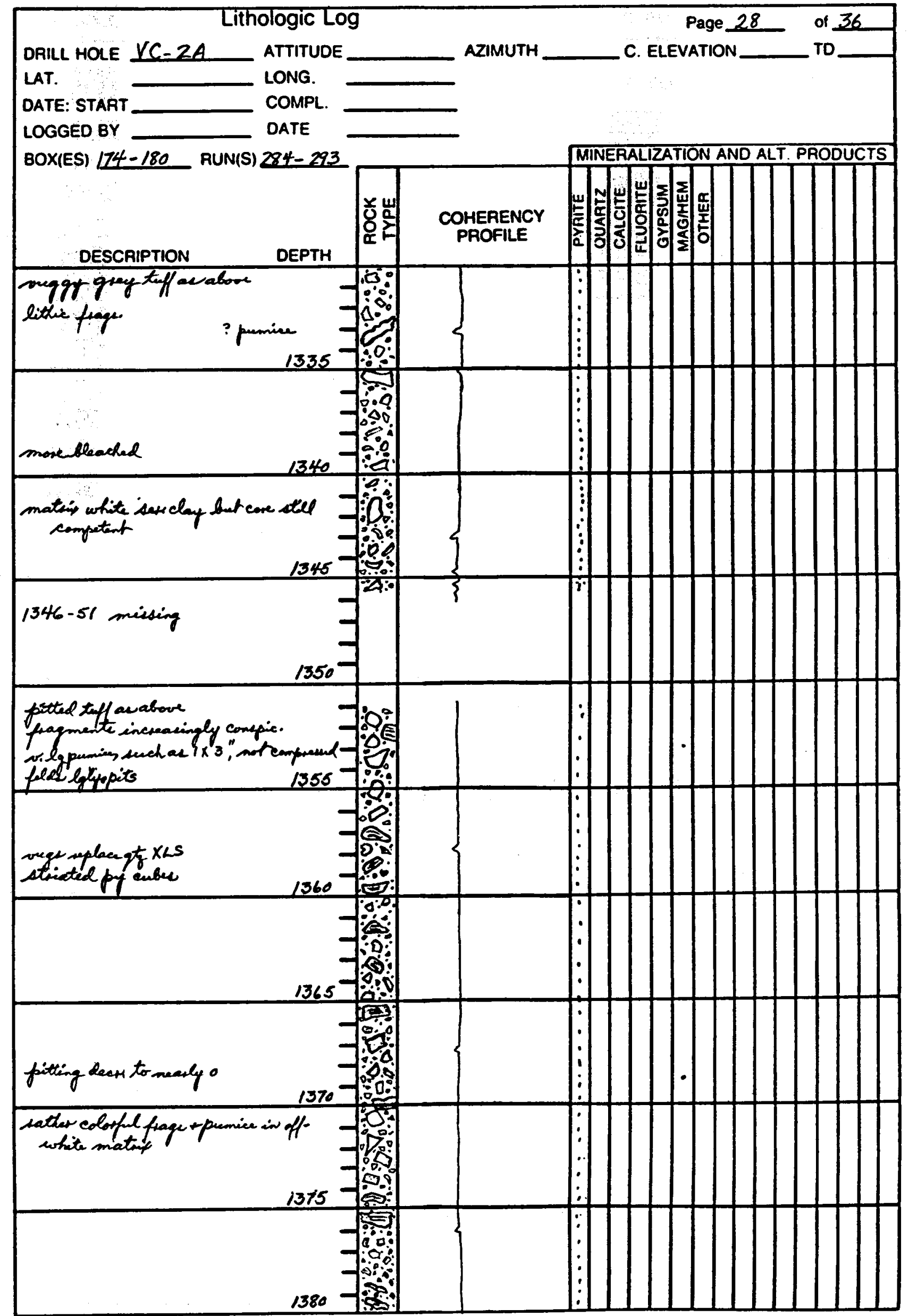




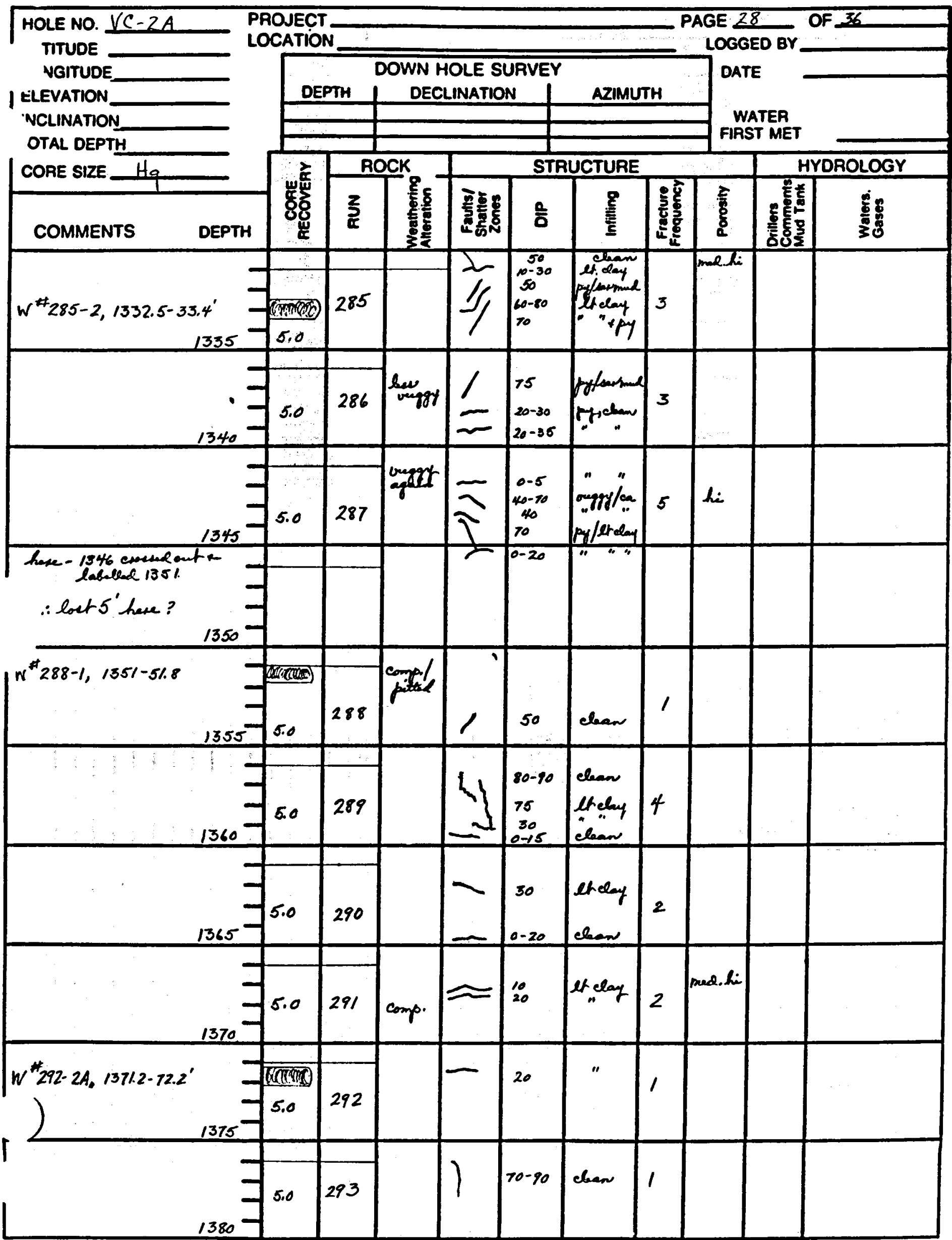




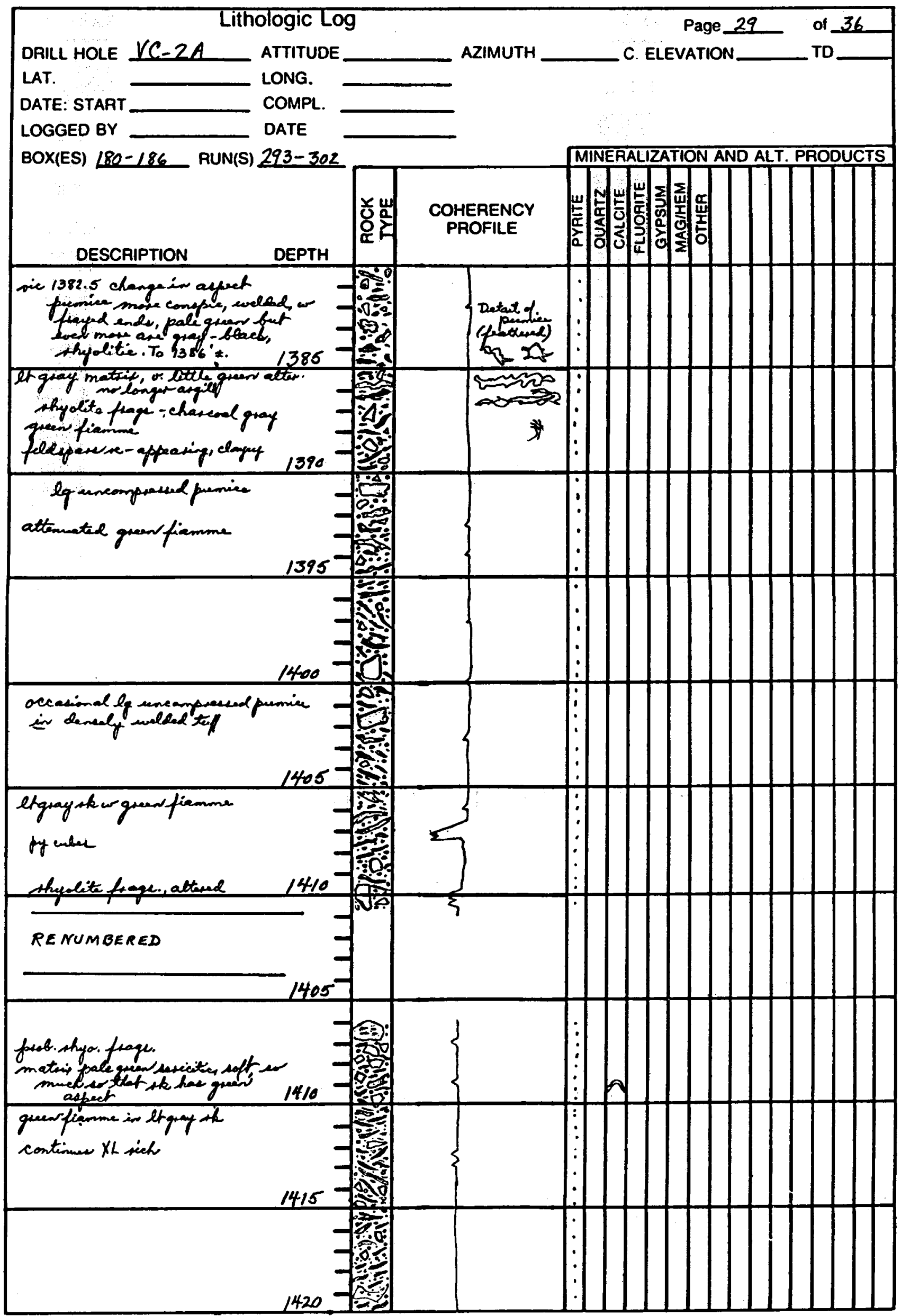




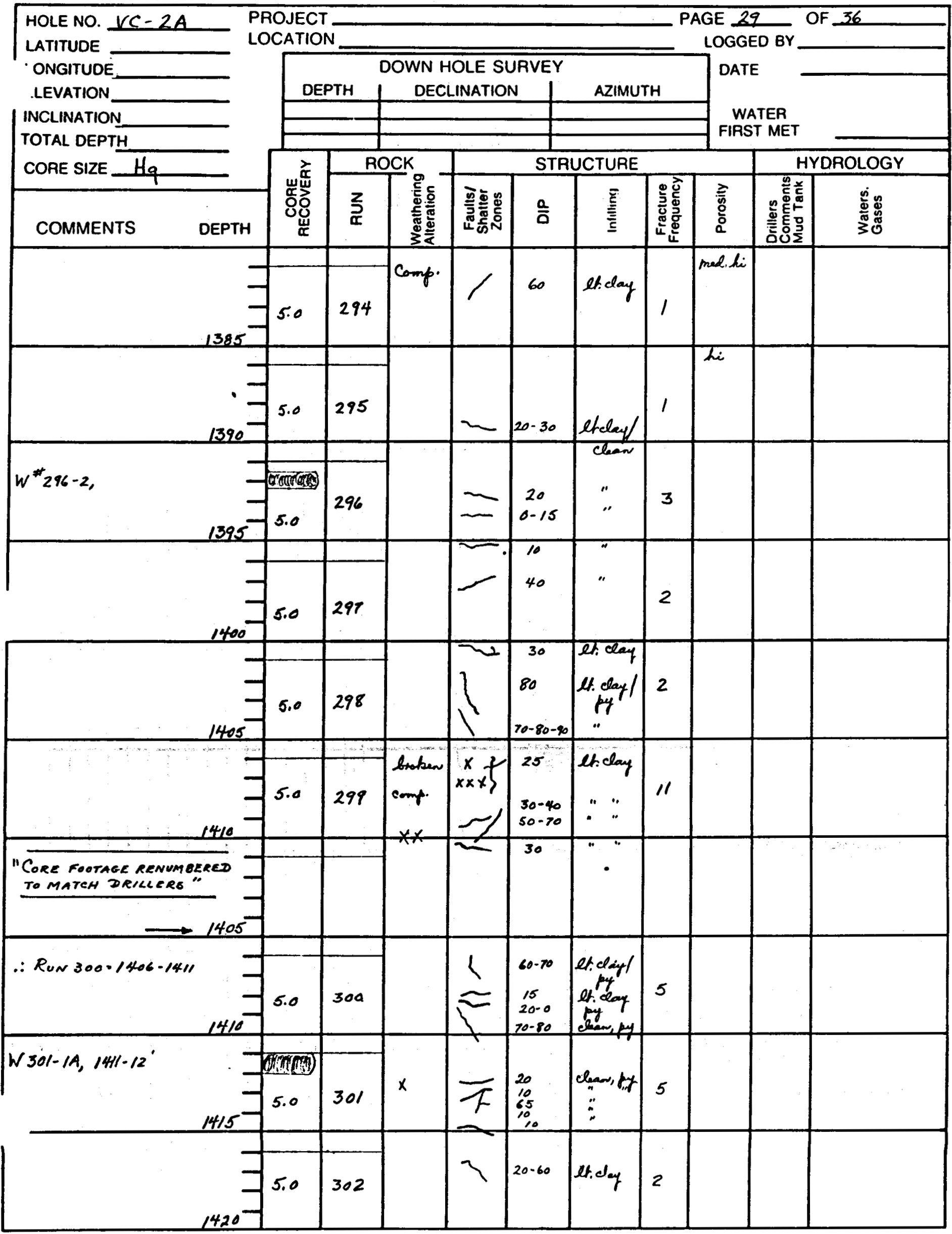




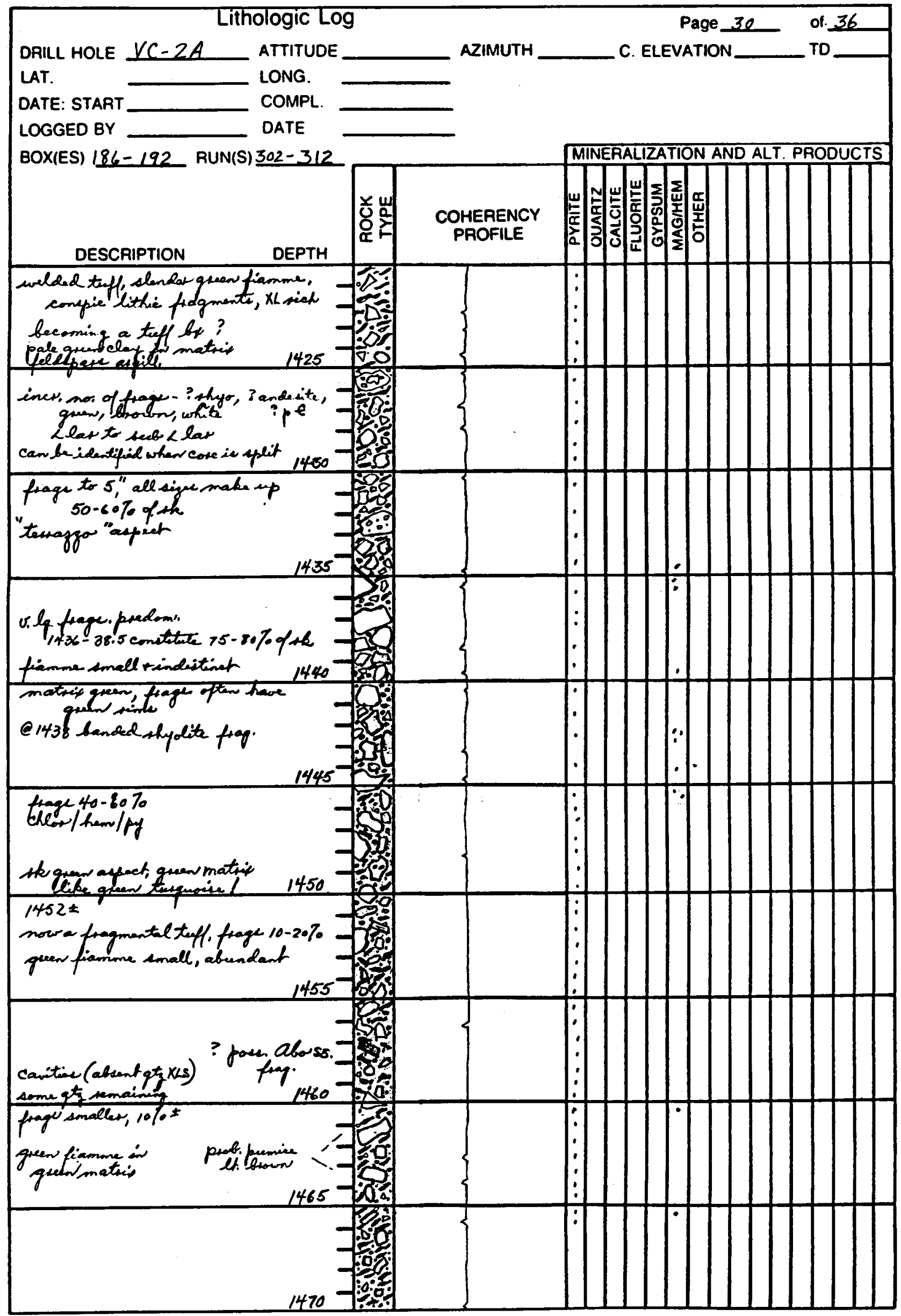




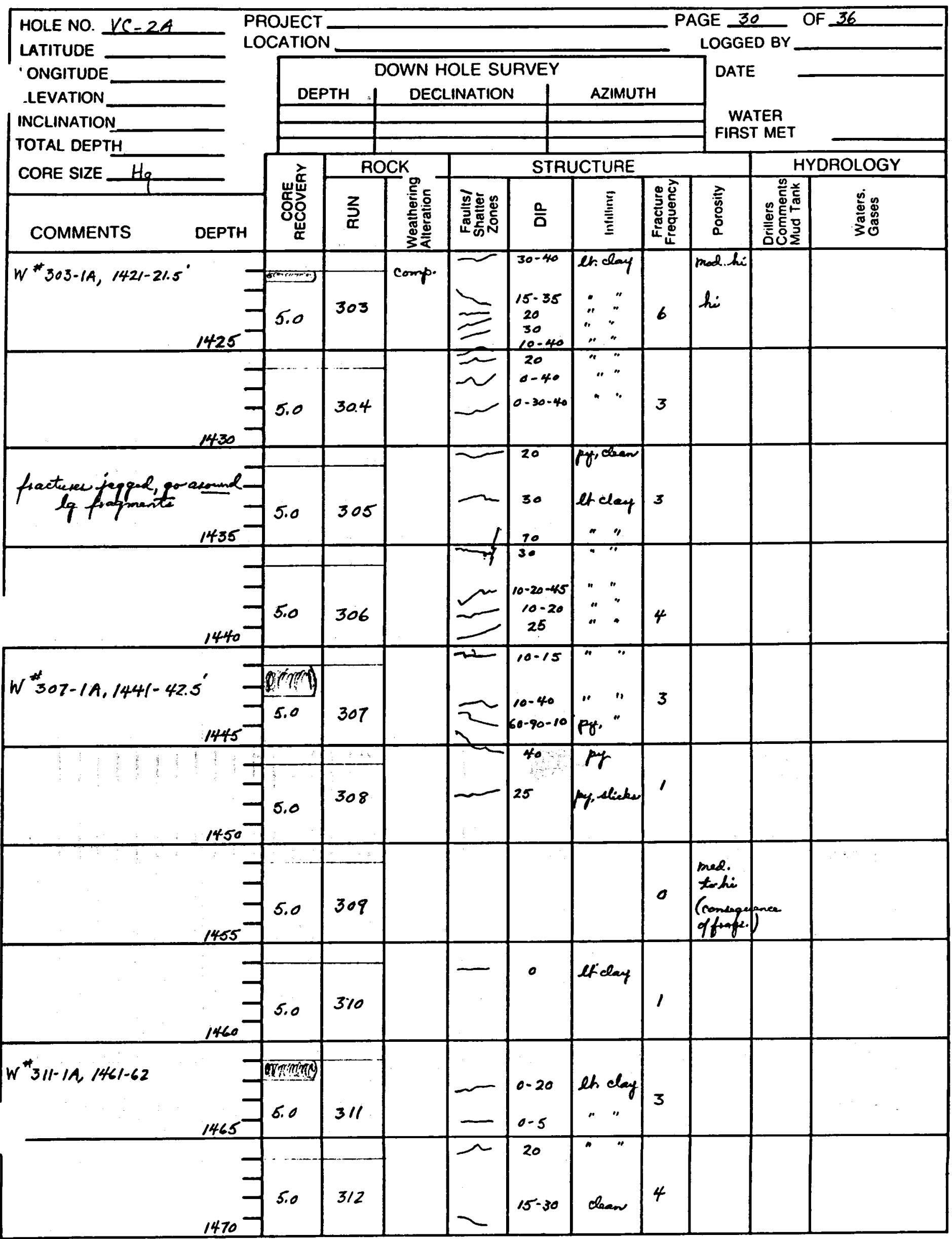




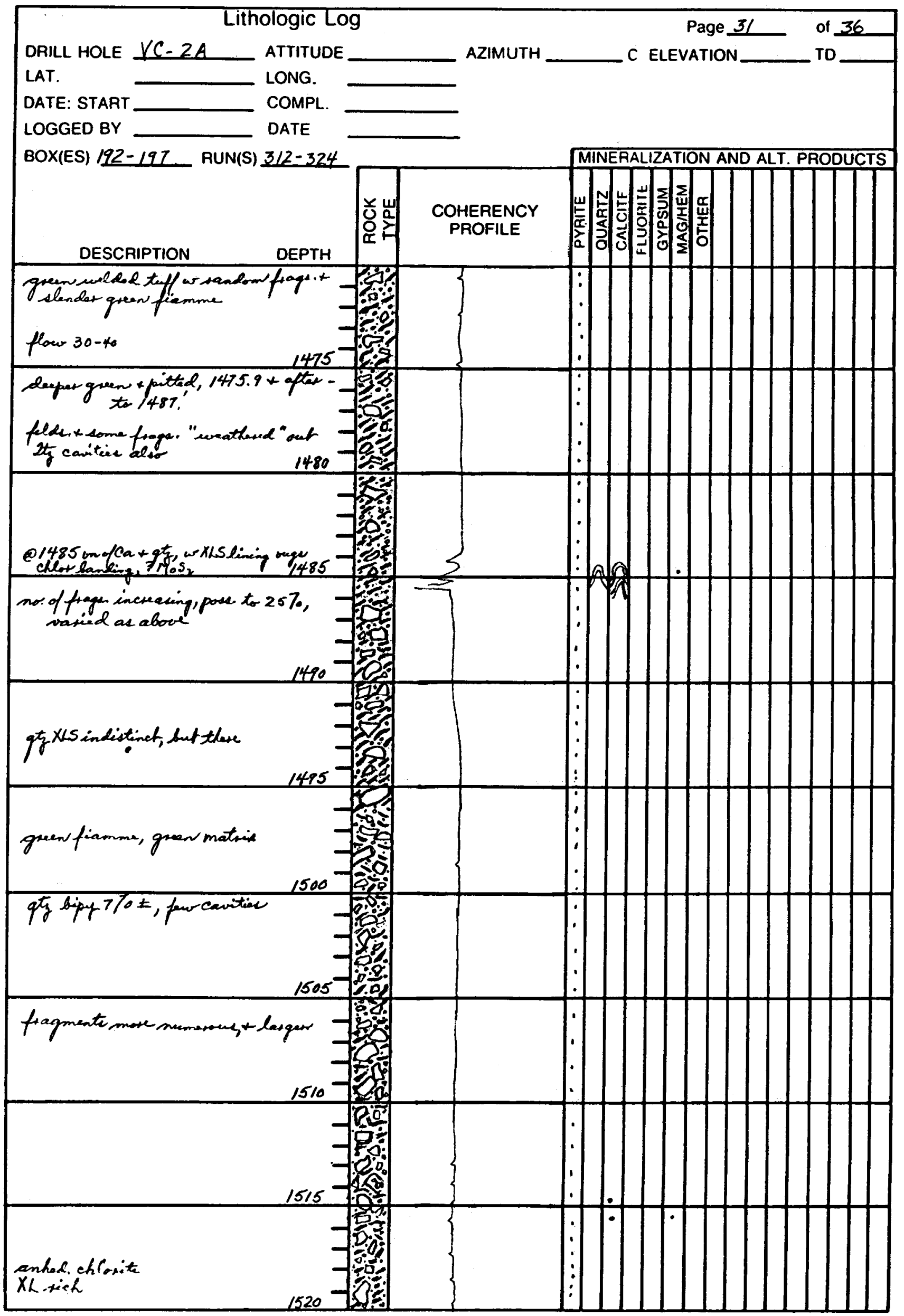




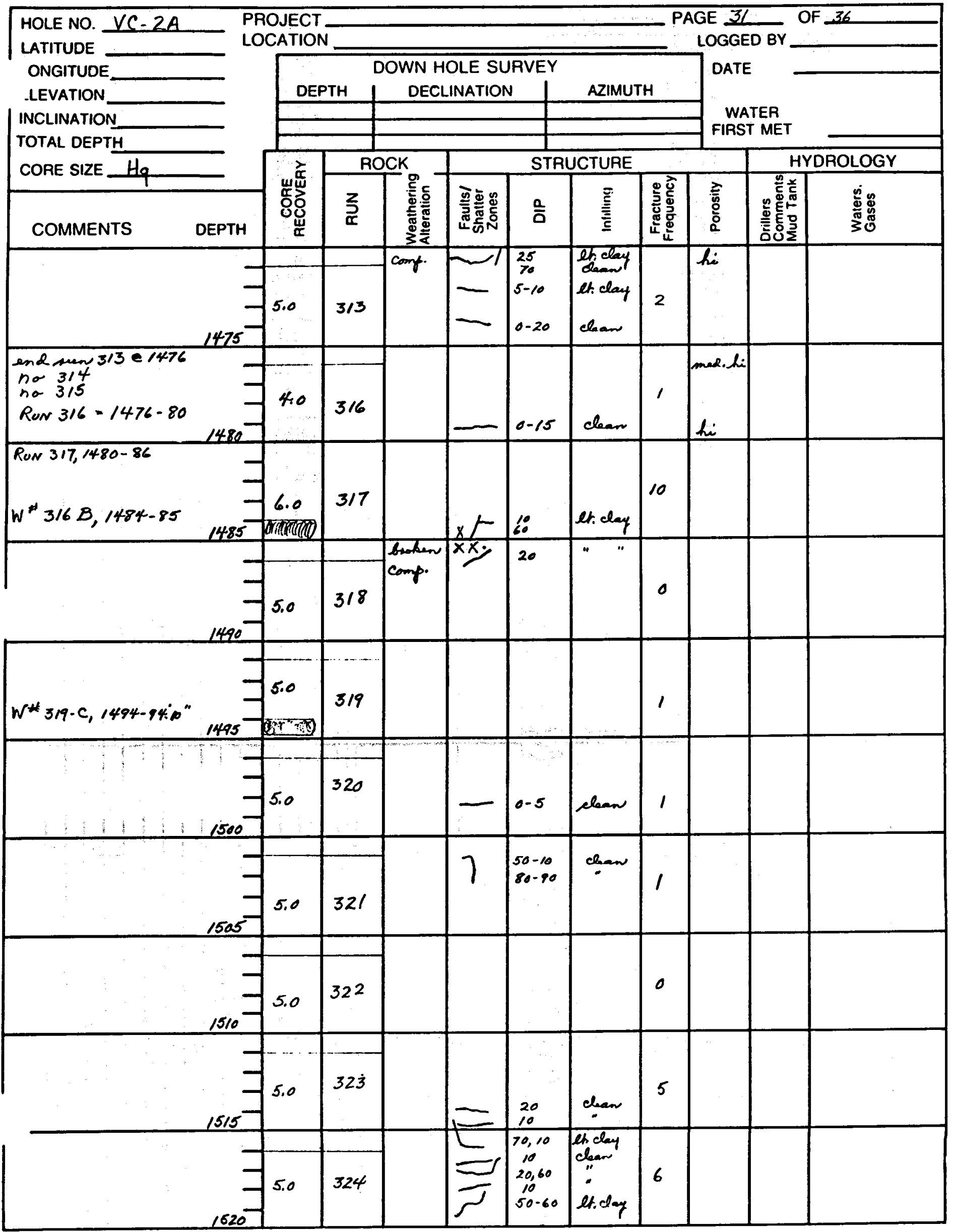




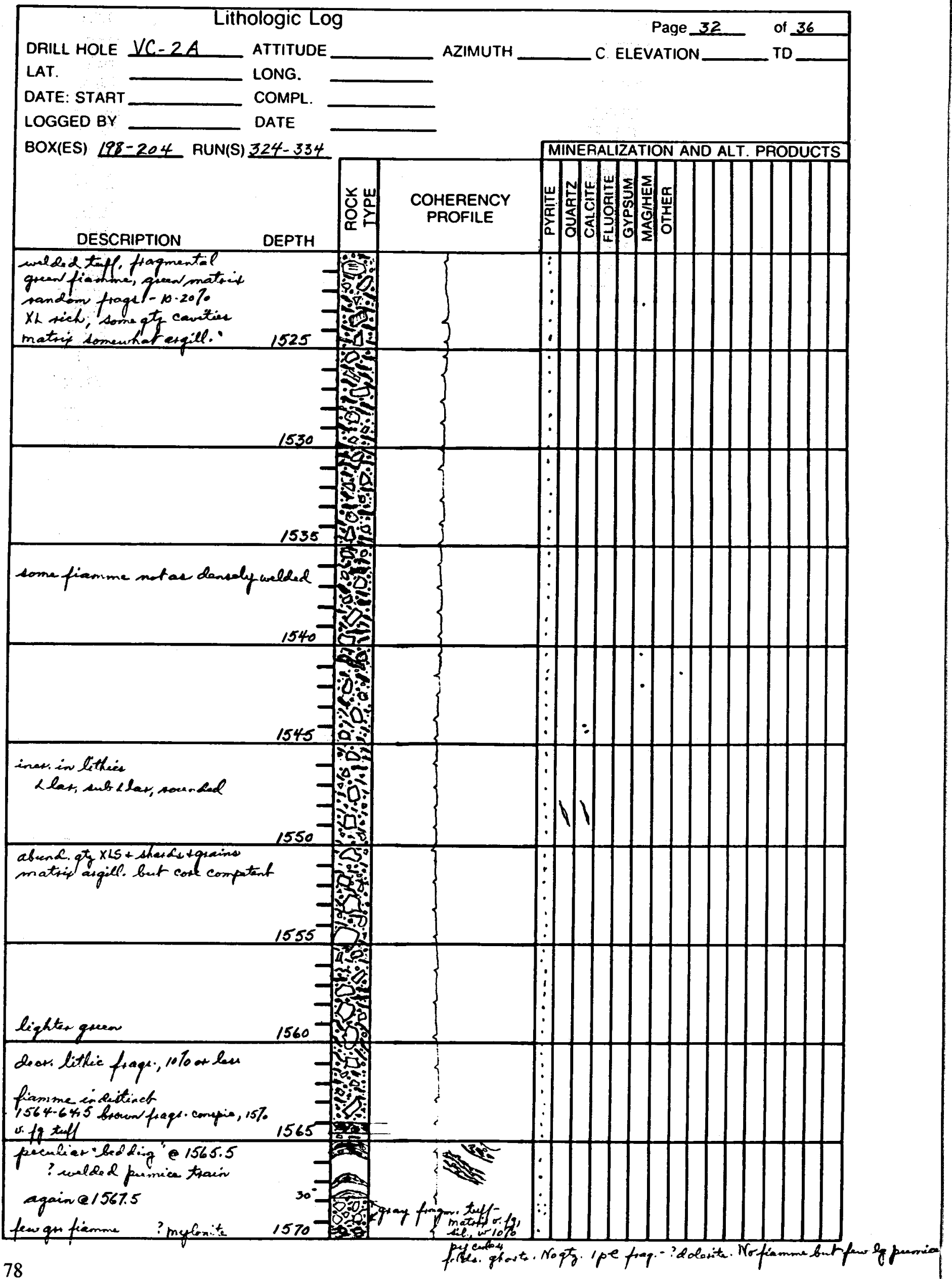




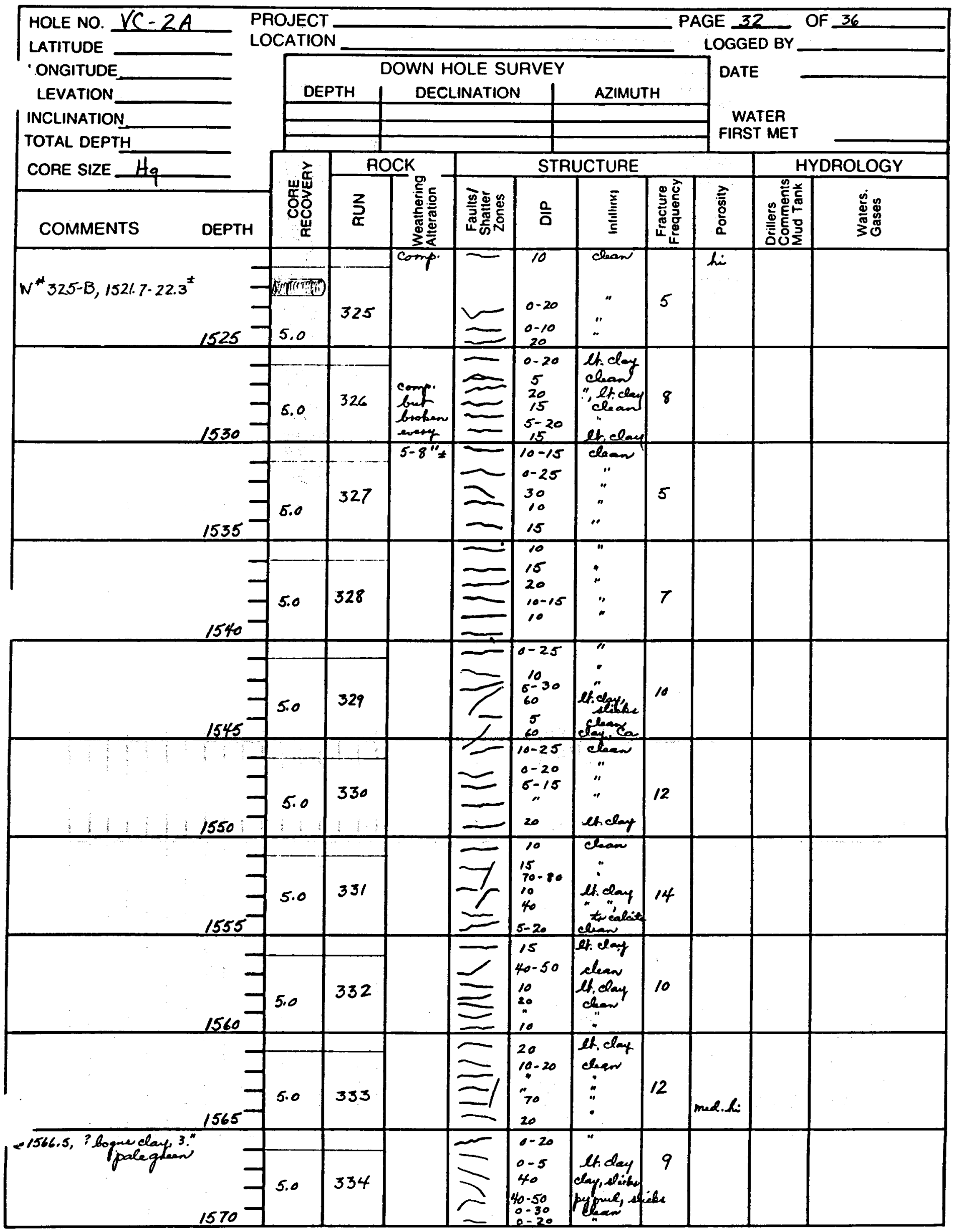




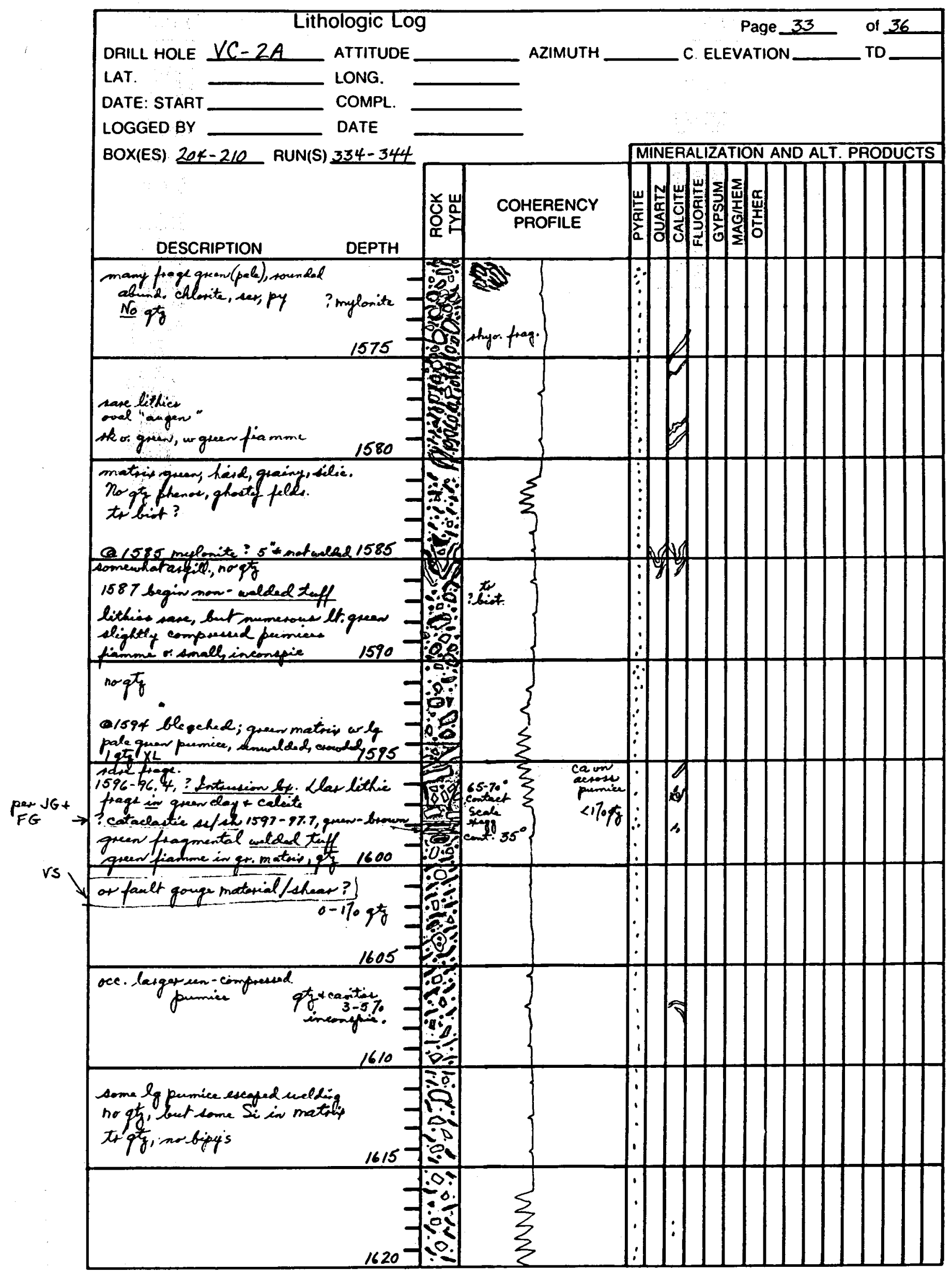




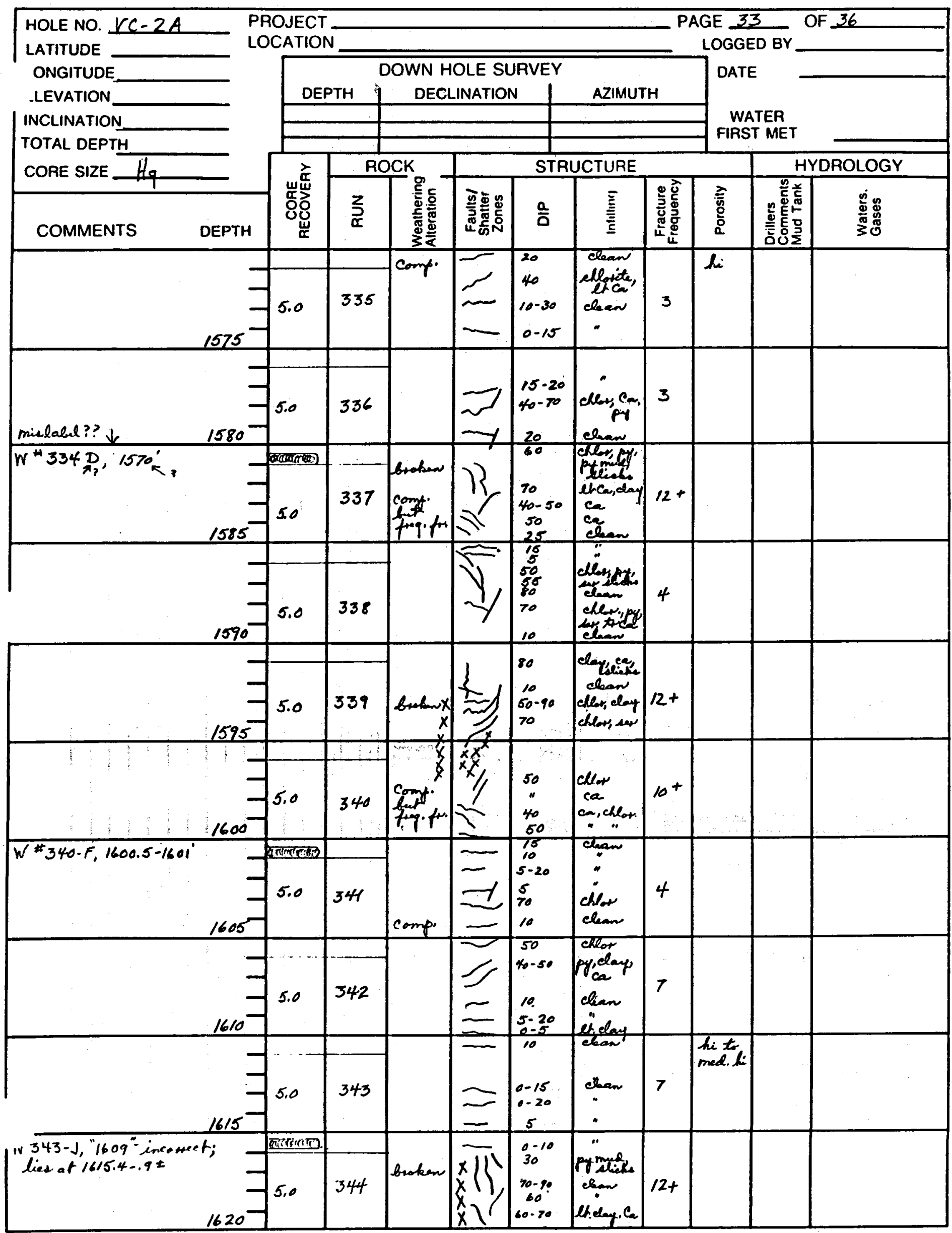




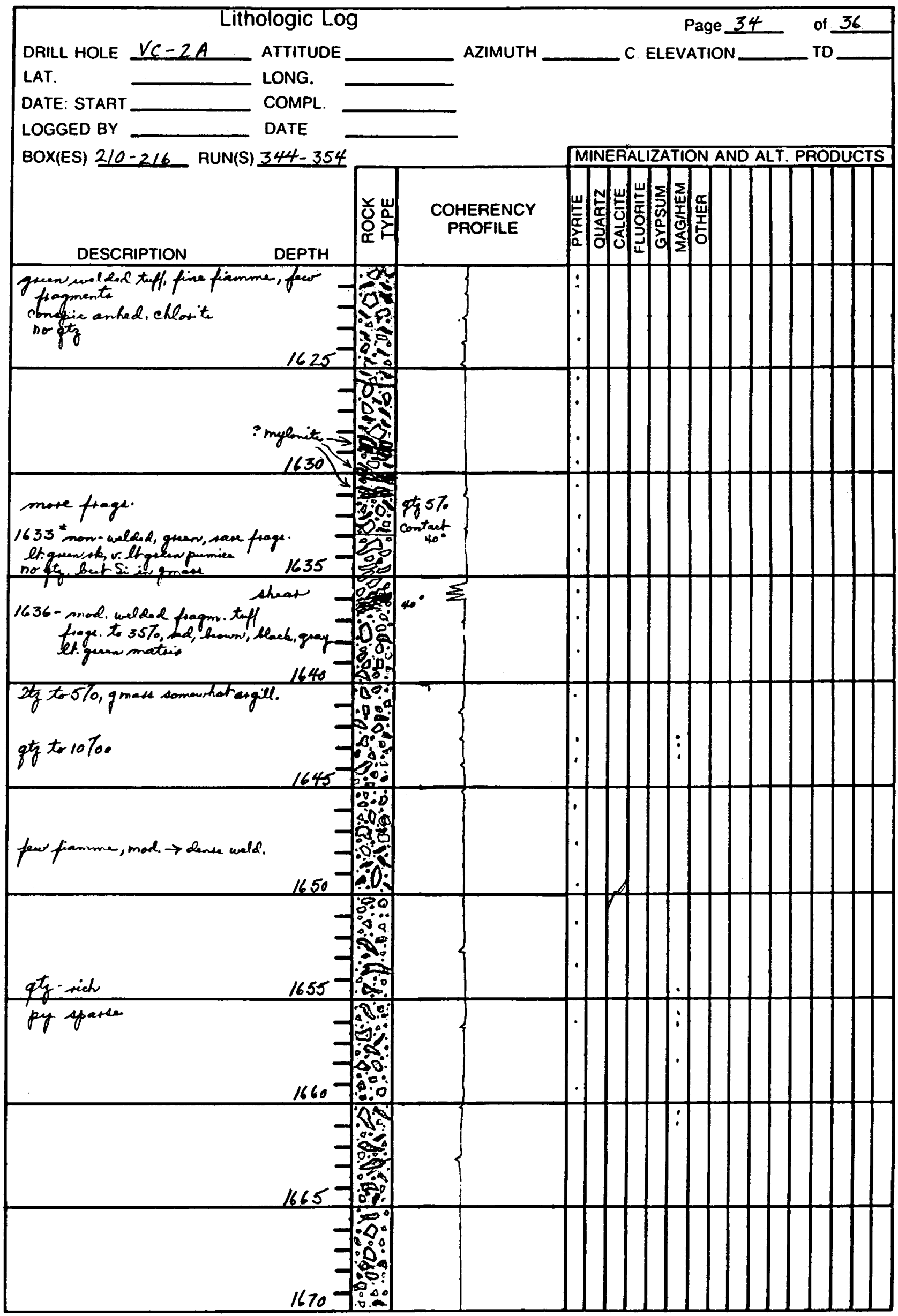




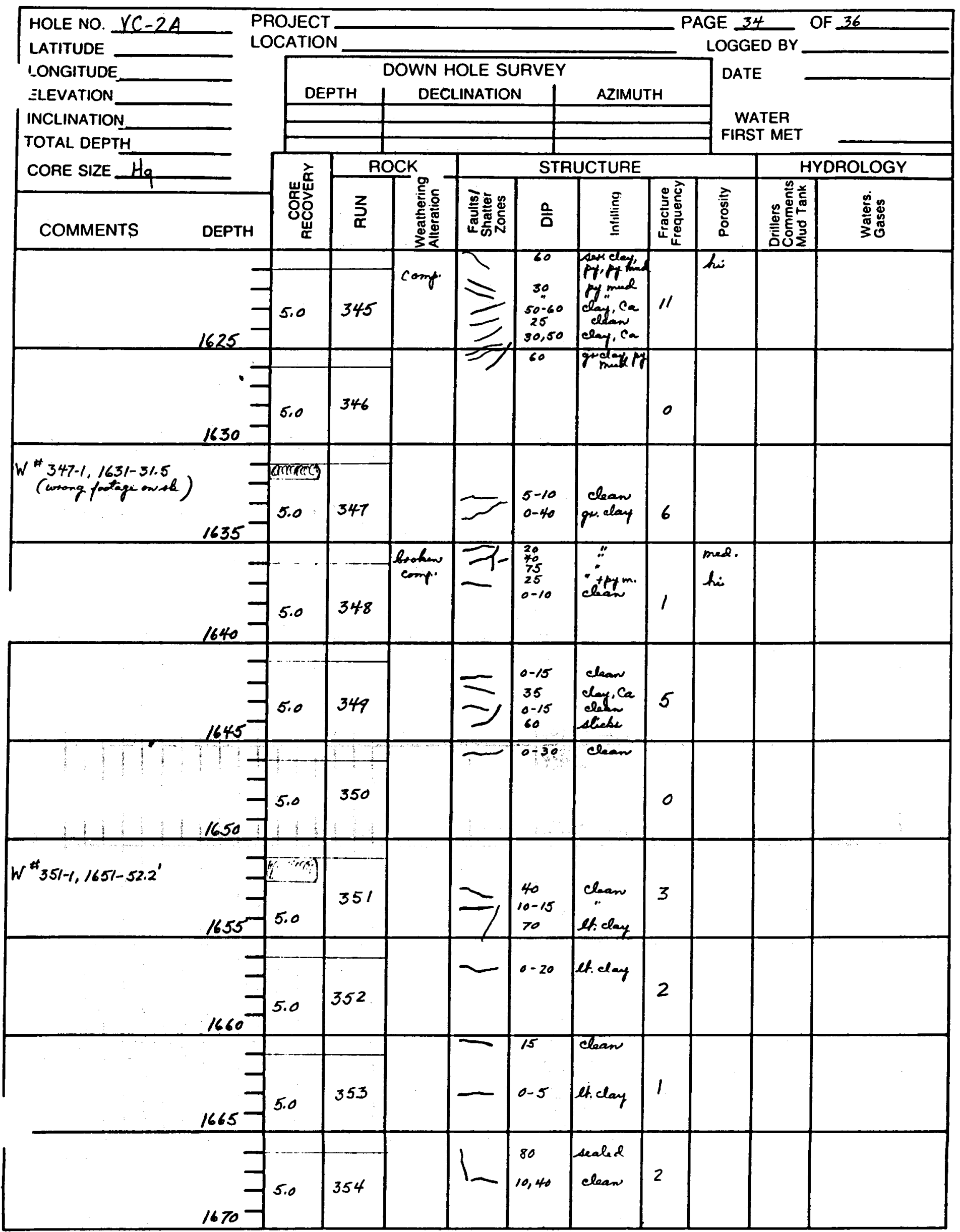




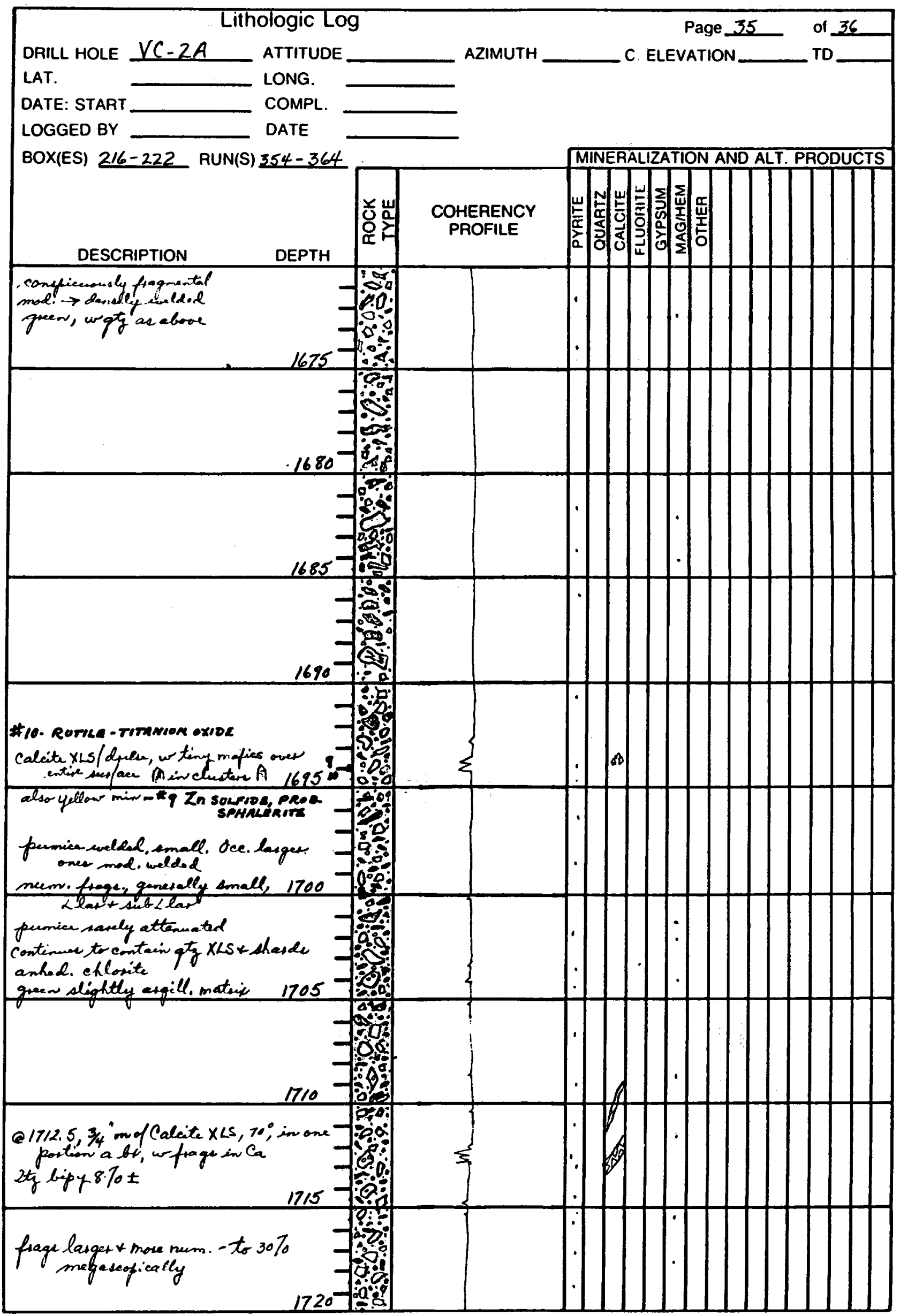




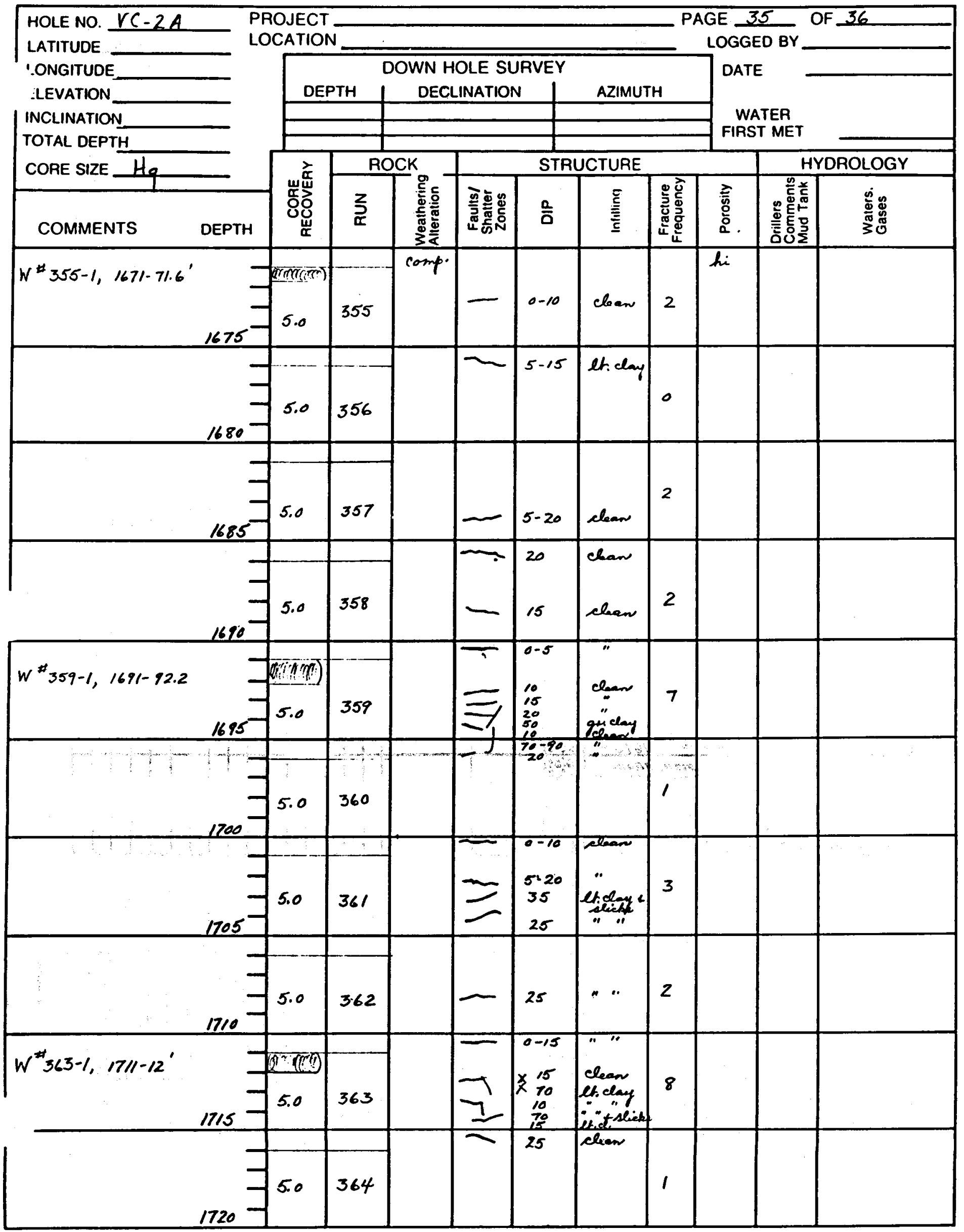




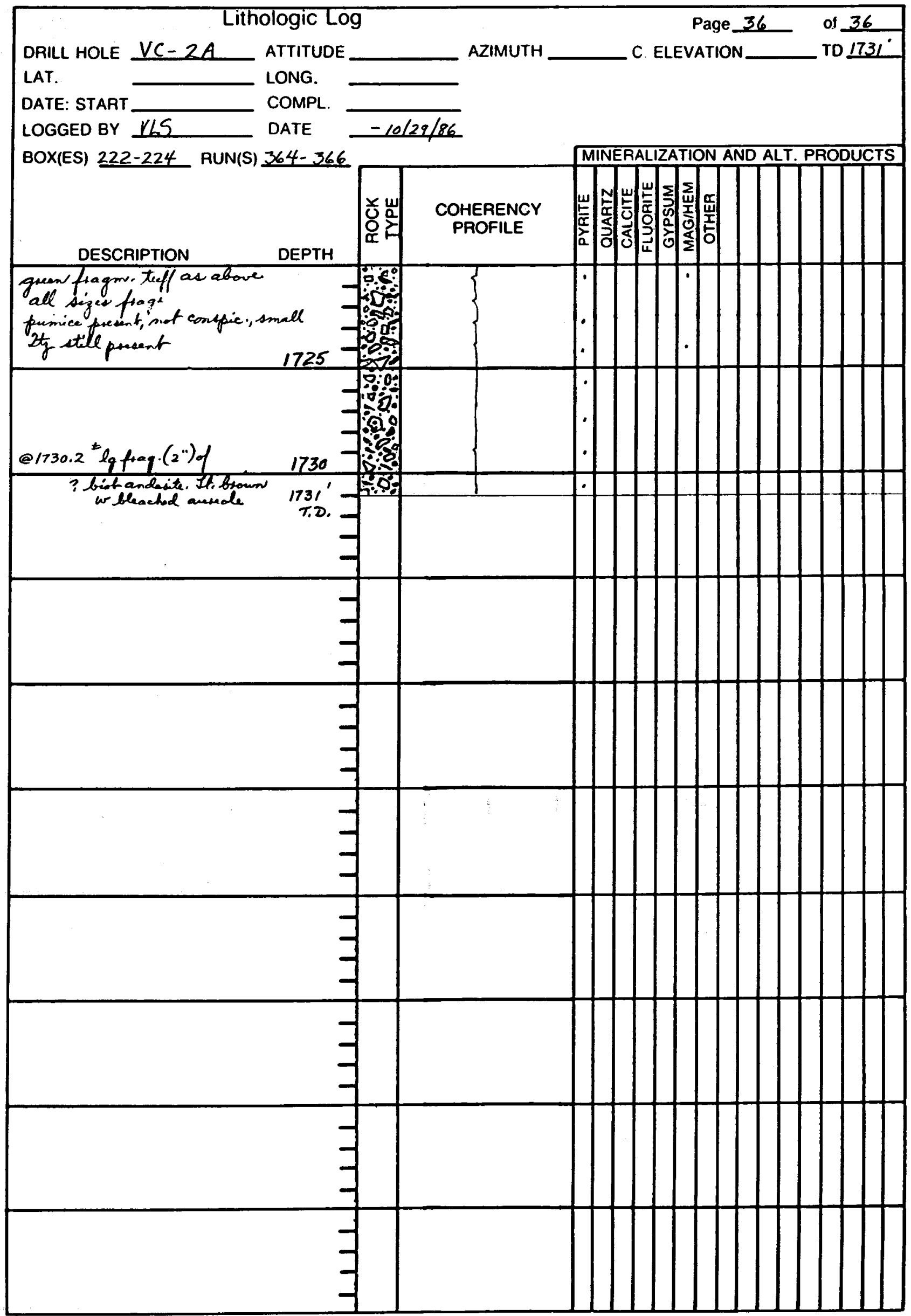




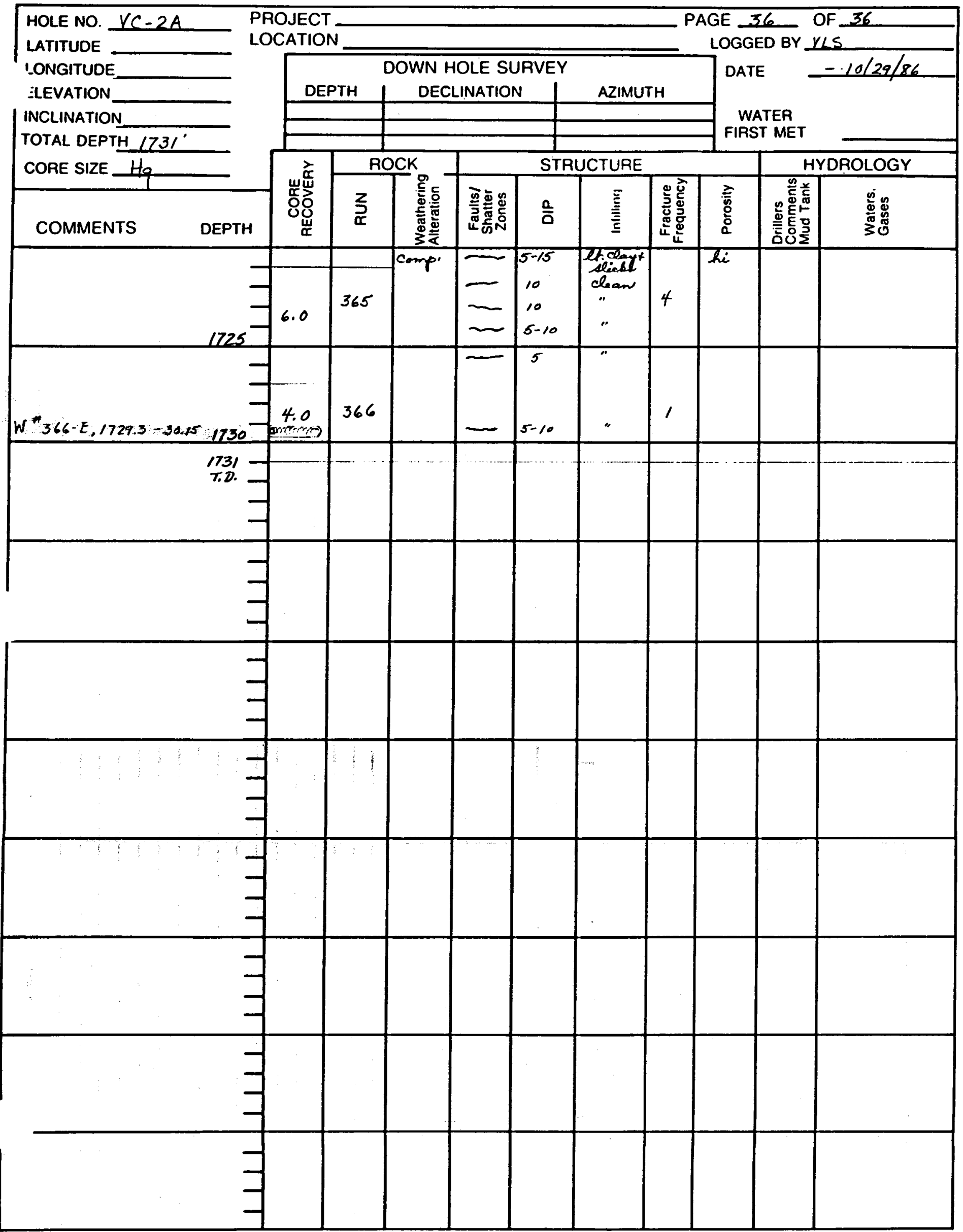




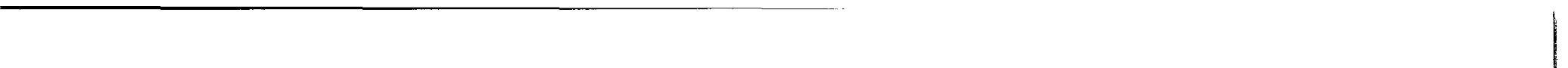

